CLAUDIA LORENA ESQUIVEL GARCÍA

\title{
Energia eólica no setor elétrico brasileiro segundo a perspectiva do direito ambiental: análise comparada e integrações regionais
}

Tese apresentada à Escola Politécnica da Universidade de São Paulo para obtenção do título de Doutor em Ciências. 
CLAUDIA LORENA ESQUIVEL GARCÍA

\section{Energia eólica no setor elétrico brasileiro segundo a perspectiva do direito ambiental: análise comparada e integrações regionais}

Tese apresentada à Escola Politécnica da Universidade de São Paulo para obtenção do título de Doutor em Ciências.

Área de concentração:

Engenharia Elétrica

Orientador:

Prof. Dr. José Aquiles Baesso Grimonni 
Autorizo a reprodução e divulgação total ou parcial deste trabalho, por qualquer meio convencional ou eletrônico, para fins de estudo e pesquisa, desde que citada a fonte.

Este exemplar foi revisado e corrigido em relação à versão original, sob responsabilidade única do autor e com a anuência de seu orientador.

São Paulo, de de

Assinatura do autor:

Assinatura do orientador:

\section{Catalogação-na-publicação}

García, Claudia Lorena Esquivel

Energia eólica no setor elétrico brasileiro segundo a perspectiva do direito ambiental: análise comparada e integrações regionais / C. L. E. García -versão corr. -- São Paulo, 2018.

$152 \mathrm{p}$.

Tese (Doutorado) - Escola Politécnica da Universidade de São Paulo. Departamento de Engenharia de Energia e Automação Elétricas.

1.Energia eólica 2.Direito ambiental 3.Integração regional 4.Políticas públicas I.Universidade de São Paulo. Escola Politécnica. Departamento de Engenharia de Energia e Automação Elétricas II.t. 
Dedico este trabalho ao meu marido Mario Fernando Gonzalez pela sua incondicionalidade em toda nossa viagem juntos. A nossa filha Eloisa pela força que me da para ser cada vez melhor. 


\section{AGRADECIMENTOS}

A Deus pelo milagre da vida.

Ao meu orientador Prof. José Aquiles Baesso Grimoni pela confiança e pela generosidade para compartilhar o conhecimento. Aos professores e colaboradores do PEA pelo apoio e oportunidade de abrir o espaço acadêmico para os trabalhos multidisciplinares, em especial a Claudio Galvão, Miguel Udaeta, Marco Saidel, Carlos Marcio Tahan. À Rede Iberoinnova da Univerisdade Rey Juan Carlos de Espanha pela oportunidade de participação no programa CEISEP II, especialmente à professora Susana Galera. À Universidade de San Buenaventura de Cali e à Universidade Javeriana de Cali por me abrir um espaço acadêmico ao meu retorno na Colômbia. A minha mão Luz Marina Garcia pela força e a alegria com que me ensino a encarar a vida, a todas minhas tias Olga, Zulma, Sonia, Miriam e Mariala por seu carinho e dedicação. A minha caríssima irmã Ana Maria pela sua presencia na minha vida que tem sido determinante para me sentir encaixada no mundo.

A meus amigos e pais adotivos no Brasil Lilian e Paulo Okura e a meu Caro Paulinho por me fazer sentir sempre em casa. A meus amigos pelo apoio incondicional: Leonardo Villabón, Catherine Bocanegra, Mathias Büttner, Adriana Gomez, Enrique Franco, Luis Varela, Francy Sanchez, Paula Faria, Alexandre Faria, Beta Prates, Gustavo Patiño, Wilmar Calderon, Nathalia Ervedosa, Alexandre Vasconcelos, Patricia Tejada, Dairo Mesa, Jenny Gonzalez, Valdomiro Veja, Olga Pelaéz, Julieta Puerto Rico, Pascoal Rigolin, Helio Goldestein, Marlene Goldestein, João Goldestein e Andrés Ovalle.

E em geral a todos os que me ajudaram a fazer a vida leve durante este período de minha vida. 


\section{RESUMO}

O presente trabalho aborda em primeira instância as contribuições do direito ambiental e sua dimensão axiológica a partir do princípio de desenvolvimento sustentável, no processo de construção do modelo ambientalmente harmônico no setor elétrico. Isto segundo o viés da teoria da justiça aplicada ao direito ambiental é afirmar, identificando os elementos de justiça ambiental, a sua importância na consolidação do arcabouço normativo aplicável à energia eólica. Posteriormente efetua-se a analise da ação racional dos Estados e da sociedade internacional perante o fenômeno de mudança climática, como causa relevante a partir da qual se institucionalizam as políticas públicas que viabilizam a inserção da fonte eólica, como elemento legitimador, da ação de planejamento do setor elétrico, com o viés do tratamento dos bens comuns; para o qual se estrutura um cenário tendencial e outro cenário sustentável do recurso eólico no caso brasileiro. Nesta mesma linha se avalia a importância da supranacionalidade e a intergovernabilidade em termos de vinculação jurídica dos estados membros, com a consequente relativização do conceito de soberania e seu efeito nas integrações regionais do Mercosul e da União Europeia, e seu efeito no comportamento da energia eólica, entendida como elemento relevante da transição energética. Finalmente, revisa-se comparativamente o modelo normativo estruturado vinculante para a energia eólica na Alemanha, na França, na Espanha e na Colômbia para a fonte eólica e o grau de segurança jurídica, assim como o nível de risco regulatório, considerando a abrupta inserção de elementos competitivos para aumentar os incentivos regulatórios.

Palavras-chave: Direito ambiental, energia eólica, políticas públicas, integração regional, desenvolvimento sustentável. 


\begin{abstract}
This work addresses the contribution of environmental law and its axiological dimension, beginning from the principle of sustainable development in the construction process of the harmonious environmentally model in the electrical sector. This is explained through applied justice theory to environmental law, by identifying elements of environmental justice and its relevance to the consolidation of regulatory framework applied to wind energy. Subsequently, the interaction between the states and the international community before the climate change phenomenon is analyzed as an important cause from which the public policies are institutionalized allowing the introduction of wind power as a legitimating element for planning in the electrical sector through the common goods. For this, a tendential scenario and another sustainable scenario of the wind resource in the Brazilian case are structured. In this regard, the importance of supranationalism and intergovernamentalism in terms of legal link of the member states are evaluated, with the consequent relativization of the concept of sovereignty and its effect on the regional integrations of Mercosur and the European Union and the effect on wind energy, understood it as a relevant element of energetic transition. Finally, I make a comparative review of the binding normative model for wind power generation in Germany, France, Spain and Colombia, and the degree of legal security, as well as the level of regulatory risk considering the abrupt insertion of competitive elements to have access to regulatory incentives.
\end{abstract}

Keywords: Environmental law, wind energy, public policies, regional integration, sustainable development. 


\section{LISTA DE FIGURAS}

1 Evolução mundial da capacidade instalada de energia eólica . . . . . . 28

2 Evolução da capacidade Instalada de Energia Eólica no Brasil (ABEEOLICA, 2011) . . . . . . . . . . . . . . . . . . . 67

3 Projeção do crescimento da Capacidade Instalada de Energia Eólica. Fonte: Elaboração própria . . . . . . . . . . . . . . . . . . . . . 67

4 Fluxograma dos atributos e subatributos da dimensão política. . . . . . 72

5 Crescimento populacional (fonte: elaboração própria baseado nos dados do IBGE) . . . . . . . . . . . . . . . . . . . . . . 76

6 Projeção de Consumo por Classe de Serviço 2012- 2060 (fonte: elaboração própria). . . . . . . . . . . . . . . . . . . . . . . . 77

7 Consumo atendido por energia eólica no mundo (fonte: ABEEOLICA). . 79

8 Participação das fontes de geração de energia entre o ano 2011 e 2021 (fonte: EPE). . . . . . . . . . . . . . . . . . . . . . . . . . . 81

9 Mapa eólico da Espanha (fonte: WWE 2016). . . . . . . . . . . . . . . . 96

10 Plataformas da transição energética na Alemanha (fonte: BMWi) . . . . 100

11 Mapa eólico da Alemanha (fonte: WWE 2016). . . . . . . . . . . . . . . 107 


\section{LISTA DE TABELAS}

1 Indicadores utilizados para a geração de energia elétrica. . . . . . . . 46

2 Porcentagem de participação de energia eólica no total de consumo de energia. . . . . . . . . . . . . . . . . . . . . . 69

3 Evolução do consumo de energia desde 1995 até 2012 . . . . . . . . 78

4 Relação de GW gerados e redução de emissões de $\mathrm{CO}_{2} \ldots \ldots$. . . . 81

5 Estratégia europeia para energia e desenvolvimento sustentável. . . . . 88

6 Capacidade de interligação internacional dos países de Mercosul. . . . 88 


\section{LISTA DE ABREVIAÇÕES}

ANEEL Agencia Nacional de Energia Elétrica

BIG Banco de Informações de Geração

BNDS Banco Nacional de Desenvolvimento

CCEE Câmara de Comercialização de Energia Elétrica

CNPE Conselho Nacional de Política Energética

CONAMA Conselho Nacional do Meio Ambiente

EIA Estudo do impacto ambiental

EPE Empresa de Pesquisa Energética

FIT Feed-in Tariff

IBGE Instituto Brasileiro de Geografia e Estatística

ICMS Imposto de Circulação de Mercadorias e Serviços e Imposto

IPI Imposto sobre Produtos Industrializados

MME Ministério de Minas e Energia

ONS Operador Nacional do Sistema

$\mathrm{PCH} \quad$ Pequenas centrais Centrais hidrelétricas Hidrelétricas

PPP Parcerias Público Privadas

PROINFA Programa de Incentivo às Fontes Alternativas de Energia Elétrica

RIMA Relatório de Impacto Ambiental

SPE Secretaria de Planejamento e Desenvolvimento Energético

TCU Tribunal de Contas da União

UE União Europeia

ZDE Zone de Développement Éolien terrestre 


\section{SUMÁRIO}

1 Introdução 1

1.1 Justificativa . . . . . . . . . . . . . . . . . . 4

1.2 Metodologia . . . . . . . . . . . . . . . . . . 7

1.3 Objetivos . . . . . . . . . . . . . . . . . . . . . . . . . 10

1.3.1 Objetivo Geral . . . . . . . . . . . . . . . . . . . . . 10

1.3.2 Objetivos Específicos . . . . . . . . . . . . . . . . . . . . 10

2 Energia eólica desde a perspectiva do direito ambiental 12

2.1 Direito ambiental e sua contribuição no para as energias renováveis . . 12

2.1.1 Recursos naturais como bens comuns da humanidade . . . . . 14

2.1.2 Direito Ambiental e sociedade internacional perante a transição do setor elétrico . . . . . . . . . . . . . . . . . . 17

2.1.3 Direito ambiental e economia circular e sua relação com a energia eólica . . . . . . . . . . . . . . . . . . . . . . 19

2.1.4 Reflexão sobre a energia eólica desde a perspectiva da justiça ambiental . . . . . . . . . . . . . . . . . 21

2.1.4.1 Desenvolvimento sustentável e a eficácia do direito ambiental ................... 26

2.1.5 A Energia eólica e o direito ambiental . . . . . . . . . . . . . 28

2.1.5.1 Teoria dos Bens e Serviços Públicos aplicados à Energia Eólica . . . . . . . . . . . . . . . . . . . . 29

2.1.5.2 A Exploração da Energia Eólica e a Concorrência . . . 33

2.1.5.3 Instrumentos jurídicos para a exploração da energia eólica 
3.1 Planejamento energético no Brasil e energias renováveis . . . . . . 41

3.1.1 Planejamento energético aplicado à energia eólica . . . . . . . . 43

3.2 Revisão dos incentivos mais implementados no contexto internacional para a energia eólica . . . . . . . . . . . . . . . . . . . 47

3.2.1 Feed-in Tariff para energia eólica . . . . . . . . . . . . . 48

3.2.2 Tarifa premium e bônus adicional . . . . . . . . . . . . . 49

3.2.3 Certificados Verdes . . . . . . . . . . . . . . . . 50

3.3 Políticas públicas implementadas no Brasil para energia eólica . . . . 51

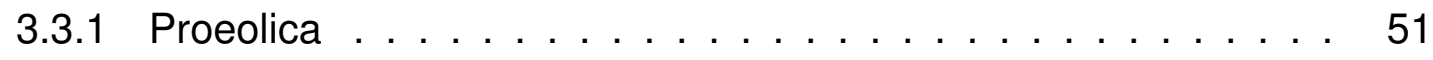

3.3.2 PROINFA: Base institucional e jurídica . . . . . . . . . . . . 52

3.3.2.1 Funcionamento do PROINFA . . . . . . . . . . . 53

3.3.2.2 Suporte financeiro do PROINFA . . . . . . . . . . 55

3.3.2.3 Analise dos riscos na participação do PROINFA . . . . 57

3.3.2.4 Principais críticas ao PROINFA . . . . . . . . 58

3.3.3 Instrumentos jurídicos que contribuem com o desenvolvimento da fonte eólica . . . . . . . . . . . . . . . . . . 59

3.3.3.1 Leilões e sua eficiência para incentivar a energia eólica 59

3.3.3.2 A propósito das energias distribuídas autoprodutores e produtores independentes .......... 60

3.3.3.3 A autorização administrativa . . . . . . . . . . . . 61

4 Caracterização do recurso eólico... $\quad 64$

4.0.1 Cenário tendencial para o recurso eólico $\ldots \ldots \ldots \ldots 6$

4.0.1.1 Previsão da oferta de energia eólica . . . . . . . . . 66

4.0.1.2 Fatores tecnológicos do recurso eólico $\ldots \ldots \ldots$ 
4.0.1.3 Viabilidade financeira dos projetos de energia eólica . . 70

Geração de Empregos: . . . . . . . . . . . . . . . . 70

4.0.1.4 Dimensão política do cenário . . . . . . . . . . . 71

Grau de aceitação do Recurso: . . . . . . . . . . . . . 71

Grau de Motivação dos agentes: . . . . . . . . . . . . . 73

Conjunção e Encontro de Interesses: . . . . . . . . . . . 74

Propriedade do Recurso: . . . . . . . . . . . . . . . . . . 74

4.0.2 Previsão de demanda . . . . . . . . . . . . . . . . . . . . 75

4.0.2.1 Crescimento Populacional . . . . . . . . . . 75

4.0.2.2 Consumo de energia elétrica por classe de serviço . . 76

4.0.3 Cenário sustentável . . . . . . . . . . . . . . . . . . . . . . 79

4.0.3.1 Instrumentos regulatórios e jurídicos no cenário Sustentável . . . . . . . . . . . . . . . 81

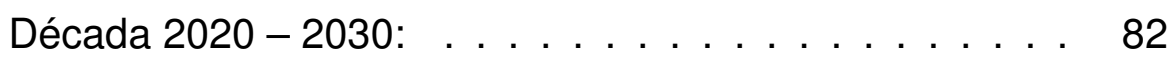

Década de $2030-2040: \ldots . . \ldots 83$

Década de $2040-2050: \ldots \ldots$. . . . . . . . . 83

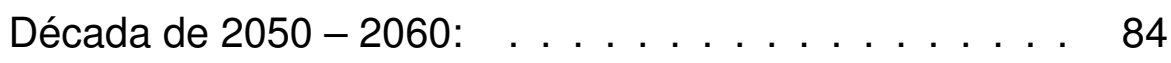

5 Integração energética regional, políticas públicas e seus efeitos 85

5.1 importância política da energia no cenário internacional . . . . . . . . 85

5.1.1 Direito de integração e seus aportes à questão de energia . . . 86

6 Comparação dos modelos normativos para energias renováveis

6.1 Particularidades na Espanha para a gestão de energias renováveis: as competências do Estado e das Comunidades Autônomas em matéria de energia elétrica e energias renováveis . . . . . . . . . . . . . . 
6.1.1 Instituições jurídicas para exercer a atividade de geração eólica na Espanha . . . . . . . . . . . . . . . . . . . . . . . . . . 91

6.1.2 Regulação para energias renováveis na Espanha . . . . . . . 92

6.1.2.1 Problemática atual da normatividade espanhola referente a energias renováveis e o caso especifico da energia eólica . . . . . . . . . . . . . . 93

6.1.3 Alemanha e sua regulação para energia renováveis . . . . . . 99 95

6.1.3.1 O planejamento energético alemão $\ldots \ldots$. . . . . 97

6.1.3.2 Legislação de energia renovável em Alemanha e seu efeito para a fonte eólica . . . . . . . . . . . . 100

6.1.3.3 Nova Abordagem Legislativa para Eólica . . . . . . . 104

6.1.4 Planejamento energético na frança em função dos compromissos internacionais . . . . . . . . . . . . . . . 107

6.1.4.1 Incentivos para energias renováveis em França . . . 108

6.1.4.2 Barreiras para as energias renováveis na França . . . 110

6.1.4.3 Irregularidades na implementação da tarifa de recompra da energia eólica. . . . . . . . . . . . . . . . 111

6.1.5 Energias renováveis na Colômbia $\ldots \ldots \ldots \ldots$. . . . . 114

6.1.5.1 Modelo regulatório para o setor elétrico e sua sustentabilidade em Colômbia . . . . . . . . . . . . . . . . . . 115

6.1.5.2 Possibilidades jurídicas para ser gerador de energia elétrica na Colômbia . . . . . . . . . . . . . . . . . . 117

6.1.5.3 Segurança energética como pressuposto para desenvolver a fonte eólica na Colômbia . . . . . . . . . . . . 120

6.1.5.4 Possibilidades de desenvolvimento da Energia eólica na Colômbia . . . . . . . . . . . . . . . . . . . . . . . 121 
6.1.6 Risco Regulatório para a Energia eólica segundo a análise dos países comparados . . . . . . . . . . . . . . . 125

7 Conclusões 127

7.0.1 Trabalhos Futuros $\ldots \ldots \ldots \ldots \ldots$

Referências 


\section{INTRODUÇÃO}

Quando se fala do setor elétrico de imediato surge seu vínculo com o conceito de desenvolvimento. Por anos o desenvolvimento econômico tem preponderado sob o desenvolvimento sustentável, não obstante perante a iminência das necessidades ambientais, torna-se indispensável uma nova abordagem da relação homem natureza e sua intrínseca conflitualidade de interesses. Portanto se aborda inicialmente uma análise a partir das contribuições do direito ambiental, que da o tratamento jurídico dos bens comuns à humanidade, tal como são os recursos naturais do vento, da água, do sol e os resíduos com os que se produz a biomassa, vinculados à geração da energia renovável. Sem dúvida, o que esta acontecendo com transição à energia renovável representa também novos paradigmas para o direito ambiental, e vem a dinamizar ou renovar categorias jurídicas preestabelecidas.

Inserir uma fonte renovável na matriz elétrica e no passo acelerado que tem sido desenvolvida no Brasil a fonte eólica, representa desafios para diversas áreas do conhecimento como são as áreas jurídicas, ambientais, econômicas e logicamente para a engenharia. $\mathrm{O}$ estudo deste processo é um tema que certamente envolve um aspecto de técnica legislativa e normativa que abrange desde o planejamento do setor elétrico, o desenho da legislação e finalmente as políticas públicas como instrumento de afrontar uma questão estrutural do desenvolvimento das fontes renováveis.

Para efeito de análise da função da técnica legislativa e do planejamento do setor elétrico do Estado, considera-se também uma visão comparada da inserção da fonte eólica na matriz elétrica, vislumbrando as metas das políticas nacionais energéticas. Adicionalmente, analisa-se que em quanto em outras latitudes não só se desenham específicas metas para energias renováveis, eficiência energética e até redução de consumo de energia como metas do setor elétrico, no Brasil por sua condição de país emergente o incremento do consumo de energia é inevitável, condição que acentua as necessidades de investimento em energias alternativas. No cenário atual existe uma urgência na preservação do meio ambiente, isso leva a pensar nas energias renováveis como uma opção impreterível, e entre as energias alternativas, a energia eólica emerge com capacidade de responder aos requerimentos do sistema e do mercado 
elétrico brasileiro.

Para abordar os objetivos da pesquisa, o trabalho se estrutura em seis capítulos para percorrer os desafios normativos, regulatórios e de planejamento para a incorporação da energia eólica na matriz elétrica brasileira. Vislumbra-se também uma visão comprada de inserção da fonte eólica com países como Alemanha, França e Espanha que estão mais avançados neste processo, assim como a influência das integrações regionais no processo de transição do setor elétrico e as importantes contribuições que pode fazer o Brasil na transição do setor elétrico para países de sua região como Colômbia que apenas inicia com o desenvolvimento de energias renováveis.

No primeiro capítulo destaca-se a importância da institucionalização do direito ambiental, a importância das relações internacionais para seu desenvolvimento e seu processo de constitucionalização. Tendo em conta que esta rama do direito alberga o conteúdo axiológico referente ao desenvolvimento sustentável e a partir disto define os bens ambientais passíveis de proteção jurídica, analisam-se os mecanismos jurídicos para prevenir e mitigar os efeitos das ações que ocasionem danos ambientais e sua influência no processo de inserção da fonte eólica. Nesta linha é analisado o regime jurídico dos bens e serviço públicos e sua compatibilização com a inserção de energia eólica no contexto brasileiro. A utilização do recurso do vento pode ser ponderada como bem público, quando usado na geração de energia elétrica, e alem constitui uma atividade econômica enquadrada como serviço público sui generis, por acolher aspectos de direito privado como é a concorrência no mercado de energia. Assim, pois, serão expostas e analisadas as instituições jurídicas que possibilitam o incremento da participação da energia eólica e o interesse público que fundamenta o seu tratamento normativo e a segurança jurídica para sua consolidação.

No segundo capítulo, efetua-se uma revisão das políticas públicas para energia eólica no Brasil, com o viés metodológico que oferece o planejamento integrado de recursos. Faz-se ênfase na função de planejamento do Estado no setor elétrico, sinalizando os desafios para cumprir o objetivo de diversificar a matriz energética no Brasil e o destaque da energia eólica neste processo. Igualmente, verifica-se o funcionamento efetivo dos planos e programas que viabilizam o incremento da capacidade instalada de energia eólica. Salienta-se a importância do Programa de Incentivo às Fontes Alternativas de Energia Elétrica (PROINFA), por ser o que potencializou e con- 
cretizou os esforços para diversificar a matriz energética brasileira.

No terceiro capítulo apresenta-se a caracterização do recurso eólico como fonte de energia, tanto da oferta quanto da demanda dentro da matriz energética brasileira. Igualmente, se efetuara a construção de dois cenários energéticos para a fonte de energia eólica; o primeiro deles é um cenário tendencial, considerando as dimensões social, econômica, ambiental e principalmente política; o segundo cenário é o sustentável, onde em consideração ao potencial de energia eólica projeta-se seu potencial para oferecer uma alternativa de desenvolvimento sustentável, mediante a redução de emissões de $\mathrm{CO} 2$. A elaboração dos nomeados cenários deve originar uma previsão de demanda e oferta dos próximos 50 anos, para o qual se considera além das informações de consumo e crescimento populacional a caracterização da dimensão política e as informações dos envolvidos e interessados que tenham capacidade de decisão nos processos determinantes do planejamento e crescimento efetivo do recurso eólico.

No quarto capítulo estuda-se a relevância do fenômeno de integrações regionais para afrontar de forma estratégica os objetivos ambientais, e em particular a problemática da soberania energética, a mudança climática, e de outra parte a contribuição das energias renováveis para resolver estes problemas, quando abordadas com o viés do direito de integração. Observa-se como o assunto de energia resulta ser um fator destacado para gerar motivação à interdependência no processo de integração regional, chegando a ter nível de spill over, especificamente neste ponto se analisa a importância do tratamento a partir do direito comunitário derivado, que tem recebido o assunto energético e sua vinculação com as políticas ambientais. No quinto capítulo, analisa-se a visão comparada da implementação da normatividade e políticas específicas que incentivam à fonte eólica, na Espanha, Alemanha, França e a Colômbia e a configuração das relações jurídicas vislumbrando a relação entre o Estado e os investidores e avaliando o quesito de risco regulatório. Analise-as igualmente as transições legislativas e devido à que é um setor que esta vivenciando atualmente uma importante modificação normativa com efeitos jurídicos e econômicos. No presente estudo se faz uma tentativa por avaliar os efeitos e alcance de tal reforma. Sem perder de vista que as particulares necessidades energéticas dos pais objeto de comparação são um fator determinante para avaliar o desenvolvimento da transição energética, o 
que sem duvida tem um particular efeito na fonte eólica. No sexto capítulo para encerrar a pesquisa, se efetuam as conclusões gerais por parágrafos que correspondem e guardam harmonia com a estrutura temática dos capítulos apresentados. Por fim, se propõem trabalhos futuros que podem decorrer da presente pesquisa.

\subsection{Justificativa}

O estudo da energia eólica como fonte alternativa de geração de energia elétrica requer uma análise integral, desde a perspectiva jurídica, dos fatores em que se fundamenta a racionalidade prática das decisões políticas que incentivam o incremento da capacidade instalada, desta fonte de energia, nos níveis local, regional, nacional e internacional. O ponto de partida da presente pesquisa é a disciplina do direito ambiental e os valores e princípios que informam sua natureza, como são o princípio de desenvolvimento sustentável, o princípio de prevenção, o princípio de precaução e o princípio de rigor subsidiário. A partir dos princípios se legitima e desenvolve o direito ambiental e também servem como critérios para avaliar sua eficácia, como é o caso da avaliação dos incentivos para a fonte eólica, como ação política para mitigar a mudança climática e contribuir ao desenvolvimento sustentável.

Certamente, a sociedade internacional e dos Estados têm responsabilidade conjunta na alocação e utilização dos recursos naturais, entendendo que estes são bens comuns da humanidade. O desenvolvimento da geração de energia eólica entendida como uma dimensão da responsabilidade ambiental incorpora contribuições da teoria da justiça ambiental. Dita teoria considera que o planejamento e a gestão estratégica dos recursos naturais são ações específicas que permitem materializar a distribuição dos recursos naturais e materializar a justiça ambiental, e a geração de energia eólica esta inserida como uma ação específica em matéria ambiental.

Quando se conjugam fatores que constituem em sua essência uma questão comum à humanidade, como é a mudança climática, o estudo das ações que contribuem como é o caso do aumento dos incentivos para aumentar a capacidade instalada de energia eólica, a magnitude da problemática exige transdisciplinariedade para abordar integralmente a pesquisa. Em consideração ao anterior, se efetua uma pesquisa sobre a energia eólica como fonte alternativa de energia vislumbrando uma perspectiva 
jurídica.

Desde a técnica jurídica o processo de tomada de decisões políticas pelas distintas instituições que conformam o setor elétrico tem diferentes fases como são o planejamento, a implementação, a gestão e a avaliação dos resultados. $O$ atual processo de transição de geração de eletricidade que vislumbra incorporar energias alternativas à matriz elétrica e que esta acontecendo em diversas latitudes, implica mudanças institucionais, jurídicas e regulatórias que merecem uma análise de todo o processo decisório e dos seus resultados. Claramente a transição do setor elétrico é uma resposta à crise energética, perante esta crise o primeiro a se fazer é questionar a eficiência da função de planejamento do Estado e a pertinência do suporte institucional e das competências funcionais dos atores com ingerência nas decisões do setor elétrico. Especialmente, torna-se indispensável rever os instrumentos jurídicos e regulatórios que contribuem com as mudanças no setor elétrico e com a alocação dos recursos de energia disponíveis.

Independentemente da composição da matriz elétrica dos países selecionados para comparação nesta pesquisa e de sua preponderância em energia nuclear, carvão, hidráulica o fato é que todos se encontram abocados a efetuar uma transição há a energia renovável, para dar cumprimento aos compromissos internacionais sobre mudança climática. No caso particular do Brasil evidencia-se uma vulnerabilidade em termos de segurança energética que se evidencia quando se revisa sua matriz elétrica, em razão a sua dependência da energia hidrelétrica. Daí que surge a necessidade de aprofundar no cenário atual dos recursos energéticos renováveis e principalmente efetuar uma revisão jurídica e econômica de seu planejamento e arcabouço regulatório. Não obstante, perante o panorama atual do setor propenso sempre às crises energéticas é relevante questionar o modelo regulatório e o processo de inserção das fontes alternativas de energia.

Tendo em consideração que em diversas partes do mundo estão desenvolvendo diversos incentivos para acrescentar a participação ma matriz elétrica das energias renováveis e, entre elas a energia eólica, pretende-se abordar as questões sobre pertinência dos incentivos e a congruência que representam para o ordenamento jurídico, especialmente no que tange a risco regulatório e eficiência para atingir os objetivos das políticas do setor elétrico nacional e regional quando for o caso. Após revisar a 
dimensão jurídica do incremento de participação da energia renovável que tem acompanhado o crescimento do recurso eólico, deparamo-nos com diferentes incentivos, desenvolvidos nas legislações e analisados arduamente pela doutrina como Feed-in Tariff, tarifa Premium com bônus adicional e certificados verdes, que têm sido fundamentais para abrir espaço à energia eólica dentro do mercado elétrico e que são suscetíveis de pesquisa acadêmica.

Para tanto, e devido à influência da sociedade internacional no desenvolvimento de incentivos para energias renováveis, resulta pertinente abordar dois aspectos específicos no plano das relações internacionais: em primeira instância a visão de integrações regionais com diversos graus de integração em termos de supranacionalidade como são Mercosul e a União Europeia e sob o viés da cooperação internacional; e em segunda instância uma visão comparada e analítica da forma como tem sido decididos e implementados estes incentivos em Espanha, França, Alemanha e como estão iniciando a serem desenvolvidos na Colômbia. Pelo tanto se busca avaliar o arcabouço institucional de forma holística e balizar os incentivos em matéria de energia renovável e, concretamente os que têm impactado, maiormente à fonte eólica, assim como os ajustes incrementais que requerem estes incentivos para permitir um desenvolvimento solido e constante, ponderando a curva de aprendizado da sua aplicação progressiva.

O escopo do trabalho consiste em abordar desde a perspectiva jurídica o tema dos incentivos para a energia eólica que vão desde políticas públicas até sistemas de inserção no mercado do setor elétrico via leilões, em consideração a que os fins dos incentivos devem ser reconciliados com a técnica jurídica das instituições do setor elétrico. Isso devido, a que na medida em que o aspecto jurídico tem um efeito econômico que precisa ser harmonizado para obter resultados de maior impacto social, econômico e jurídico concordantes com os fins do Estado Social de Direito e com o princípio de desenvolvimento sustentável que norteia o direito ambiental. Sem dúvida, o direito como ferramenta da sociedade, para a consecução dos seus fins, é constantemente testado em quanto a sua eficiência e congruência das disposições normativas. Os resultados do direito ambiental, como direito positivo, redundam em prol do interesse público imerso na sociedade e porem em maior bem-estar, certamente, a energia eólica encarna esses objetivos ambientais acordes com o desenvolvimento sustentável.

A justificativa da pesquisa decorre da inexistência de tratamento doutrinário que 
tenha aprofundado na interpretação das teorias das políticas públicas e da técnica legislativa ao lume dos processos de transição energética e concretamente na inserção da fonte eólica, considerando seu potencial para se tornar a fonte mais importante dentro do desenvolvimento das energias renováveis. Igualmente, pretende-se verificar se perante a inserção das fontes de energia renovável existe uma mudança do paradigma no planejamento energético considerando inclusive a modelagem para operação da rede elétrica.

\subsection{Metodologia}

Atendendo a que o ponto de partida da análise é um ramo do direito contemporâneo como é o direito ambiental, que pela sua interdisciplinaridade na configuração dos seus categóricos teóricos ainda não tem bases suficientes, mas que tem autonomia como um ramo do direito pelo seu objeto de estudo, inicialmente trabalha-se com o método trialista (GOLDSCHMIDT, 1973). Este método abrange o plano axiológico, os fatos e a normatividade permitindo uma análise holística das problemáticas sociais quando abordados pelo direito, como é o caso da inserção da fonte eólica na matriz elétrica que contribui com o problema do aquecimento global.

O objeto de pesquisa do presente trabalho é a analise do desenho institucional sob o qual se efetua o planejamento e políticas públicas que propendem pelo crescimento do recurso eólico no contexto brasileiro e comparado. Para tanto se tem como ponto de partida a problemática iminente de realizar uma transição energética para o desenvolvimento limpo. Assim se abordaram diversas faces do planejamento e desenvolvimento elétrico que permitem consolidar a energia eólica como um recurso elétrico com o potencial de constituir-se no segundo recurso no atendimento à demanda depois da fonte hidrelétrica.

Evidencia-se na realidade da energia elétrica brasileira uma forte dependência do recurso hidrelétrico, o qual é facilmente verificável pelo histórico de atendimento à demanda de energia elétrica no banco de informações de geração (BIG) da Aneel. Segundo o BIG, a julho de 2015 a principal fonte de geração é a usina hidrelétrica com $61 \%$, seguida da termoelétrica com $28 \%$ e em terceiro lugar encontra-se a fonte de geração eólica com $4 \%$ da matriz elétrica brasileira. Pelo tanto é bastante recor- 
rente afirmar que perante ás crises hidrelétricas o principal suporte de abastecimento é a energia térmica, mas esta ultima opção resulta contraria aos objetivos de desenvolvimento sustentável e ao da matriz elétrica limpa, devido às emissões de $\mathrm{CO} 2$ e ao incremento no preço da energia.

Justamente perante este cenário torna-se indispensável que dentro da gestão governamental se elaborem políticas públicas que propendam pela diversificação da matriz energética e as energias alternativas. Para tanto a gestão governamental deve incluir os níveis micro, macro e meso institucional de tal maneira que seja possível prever diversos planos de gestão e a eficácia que se tem em cada um deles. Assim as coisas se revisaram os aspectos críticos do desenho jurídico-institucional dos diversos planos e programas que incluem o desenvolvimento de energias renováveis ponderando seu potencial e as possibilidades de desenvolvimento e a adaptabilidade técnica com o sistema elétrico brasileiro.

O aspeto crítico centra-se na identificação dos vazios jurídicos e regulatórios que tenha a normatividade vinculante para a energia eólica assim como também as possíveis incompatibilidades com o modelo regulatório brasileiro, que levem a gerar problemas de coordenação entre atores interessados e instituições. Por tanto, pretende-se neste trabalho estudar o aporte das teorias de políticas públicas e do direito na fase de transição energética para o desenvolvimento limpo, tendo como foco de pesquisa a energia eólica. Mas a pesquisa procura passar do plano meramente dogmático e levar em consideração a analise dos desafios jurídicos, econômicos, regulatórios e técnicos para incorporar com sucesso a energia eólica na matriz elétrica.

Para tal fim, elabora-se um analise sistemático dos documentos do estado da arte em matéria de incentivos regulatórios para energia eólica e seus efeitos, vislumbrando a maturidade da fonte eólica e a ponderação do seu equilíbrio econômico para que se desenvolva no mercado elétrico com o mesmo potencial de competitividade que as fontes convencionais de energia. Igualmente serão identificados os fundamentos jurídicos e econômicos do planejamento com os quais se aborda a problemática de ter uma matriz elétrica em transição, para o qual se verificam as estatísticas oficiais do setor em termos de potencial, capacidade instalada e projetos em construção de energia eólica. 
Devido a que é uma tese com um caráter multidisciplinar será ponderado o desenho institucional á luz da literatura sobre planejamento do setor elétrico o que envolve, tanto aspectos jurídicos, econômicos quanto aos atores e seus conflitos de interesse aspectos técnicos. No aspecto técnico se consideram as exigências técnicas que deve atender a energia eólica para harmonizar-se com o Sistema Interconectado Nacional SIN que apresenta características próprias de desenho e operação para energia hidrelétrica.

Por tanto na revisão bibliográfica se constataram os estudos sobre mecanismos de incentivos para a inserção de energias renováveis e os aspectos críticos do desenho institucional para a aplicação de tais incentivos para as energias renováveis. Revisarse-á também as limitações técnicas que encara a energia eólica em um sistema elétrico configurado para operar a energia proveniente de fontes hidráulica e perante 0 qual a energia eólica ainda tem desafios em termos de segurança para o SIN, sendo sua questão fundamental a otimização do seu sistema de estocagem, já que atualmente resulta inviável que seja uma energia despachável pelo Operador Nacional do Sistema.

A proposta teórica centra-se em estabelecer a validação dos instrumentos regulatórios ponderando suas dimensões jurídica, econômica e ambiental como ferramentas articuladas para temas de infraestrutura como é a energia eólica, efetuando para tal efeito uma revisão delimitação dogmática referente ás políticas públicas que se consolidam os postulados teóricos. Na sequencia, se efetuara a analise das decisões relevantes que vinculam à energia eólica verificando sua interação com a literatura própria das políticas públicas, com o qual se pretende revisar a hipótese do suporte do desenvolvimento da energia eólica e sua inserção ao setor elétrico com o viés de sustentabilidade ambiental.

Para aprofundar no assunto funcional das políticas públicas são revisadas as contribuições do neoinstitucionalismo como parâmetro metodológico, através do qual se concentram os esforços dos conhecimentos interdisciplinares, em torno do progresso em matéria de energias renováveis como objetivo socialmente relevante. No casso objeto de analise o arcabouço institucional fundamenta as mudanças nas diversas fases do processo de planificação e gestão da diversificação das fontes na matriz energética. 
O tema regulatório esta presente durante toda a discussão teórica, especialmente se descrevera com sentido critico as variáveis da transição ente os incentivos governamentais à participação com as regras de mercado e pelo tanto da concorrência. Isso por que se observa que tradicionalmente os incentivos atravessam diversas etapas como feef-in tariff, tarifa Premium e posteriormente passam a um cenário netamente de mercado. Com esta analise tentar-se-á explicar as falências de previsão do processo de inserção do recurso eólico e o cumprimento da agenda institucional de cara aos resultados que se tem, levando em consideração que o mercado parece crescer a um ritmo muito mais rápido que os arranjos regulatórios para dar satisfação a esse mercado.

\subsection{Objetivos}

\subsubsection{Objetivo Geral}

O objetivo central deste trabalho é determinar a partir do direito ambiental e da teoria da justiça, e da teoria da legislação o alcance do desenvolvimento sustentável, como plano axiológico para configurar a normatividade e as políticas públicas que incentivam o recurso eólico, determinando seus riscos regulatórios. Isso dentro do processo de transição energética, gestado e legitimado na sociedade internacional, devido à importância do tratamento internacional e cooperativo da problemática ambiental e tendo a energia eólica como fator preventivo e mitigador dentro deste contexto.

\subsubsection{Objetivos Específicos}

- Determinar as contribuições do direito ambiental e sua efetividade para o desenvolvimento da energia eólica, vislumbrada como passível de tutela jurídica pela sua contribuição ao princípio do desenvolvimento sustentável.

- Avaliar a importância da energia eólica dentro do planejamento energético do Brasil, considerando o potencial desta fonte de energia para emergir como a segunda no atendimento à demanda depois da fonte hidrelétrica.

- Verificar os aspectos críticos do funcionamento e do desenho jurídicoinstitucional dos diversos planos e programas que incluem o desenvolvimento 
da energia eólica, evidenciando sua eficácia no processo de inserção da fonte eólica na matriz elétrica brasileira.

- Efetuar a revisão do arcabouço normativo para ponderar o grau de segurança jurídica com que conta a energia eólica a fim de consolidar sua capacidade para atender a demanda. Para tanto se delimitara o regime jurídico aplicável à energia eólica e os instrumentos jurídicos que permitem seu desenvolvimento.

- Efetuar a caracterização do recurso eólico com a finalidade de efetuar um cenário tendencial e sustentável que vislumbre seu potencial de crescimento.

- Avaliar a importância das integrações regionais, em suas dimensões da supranacionalidade e da intergovernabilidade, quando abordam conjuntamente a transição energética e a importância deste fenômeno para a fonte de energia eólica.

- Avaliar comparativamente o risco regulatório e seu componente de segurança jurídica, nas transições de modelos de incentivos para a energia eólica. Ponderando o efeito dos instrumentos jurídicos para a efetividade do seu desenvolvimento da fonte eólica e sua inserção nas matrizes elétricas comparadas. 


\section{ENERGIA EÓLICA DESDE A PERSPECTIVA DO DIREITO AMBIENTAL}

\subsection{Direito ambiental e sua contribuição no para as energias renováveis}

O direito ambiental é um ramo do direito autônomo relativamente recente, que foi gestado desde os anos setenta, perante os primeiros sinais de mudança climática, fruto da proliferação de atividades industriais (ROJAS, 2007). Corresponde a seu contexto histórico também a crise do petróleo e a crise financeira mundial, as quais levaram à conclusão de que os recursos naturais são finitos e sua utilização precisa racionalização. Por isso, o uso e exploração de tais recursos requerem uma ponderação jurídica e econômica, visto que a intervenção do direito é fundamental por sua função catalisadora das problemáticas sociais.

A idéia de controle social como função última do direito atende ao caráter eminentemente prático deste e se encontra sustentada na Teoria do Direito de Hart, assim como na interpretação do direito (RAZ, 1980), que outorga o fim prático da justiça no seguinte sentido: "Ao fazer exigências o direito tem a pretensão de proporcionar 0 marco geral para a condução de todos os aspectos da vida social, e se coloca a si próprio como o supremo guardião da sociedade". Com fundamento nesta valoração do direito será interpretado o direito ambiental, especialmente o que diz respeito à eficácia no processo de inserção das fontes de energias renováveis.

Os primeiros avanços do direito ambiental se originaram por iniciativa da Organização das Nações Unidas, cuja significativa declaração de 1979 o "ano de proteção da natureza" fora influenciada pela conferência de Estocolmo de 1972. Assim, estabeleceu-se como princípio que "Os recursos naturais da terra, incluindo o ar, a água, a terra, a flora e a fauna, especialmente mostras representativas dos ecossistemas naturais, devem ser preservados em benefício das gerações presentes e futuras por meio de um cuidadoso planejamento ou ordenação".

É de advertir que a institucionalização do direito ambiental no nível internacional teve início com os tratados de pesca bilaterais assinados no século XIX, e posteriormente com a criação de organizações internacionais por volta de 1945 (SANDS, 1993). A partir da relevância da Conferência de Estocolmo foram delineados os pres- 
supostos para os subsequentes acordos sobre cuidado e conservação dos recursos naturais. Em decorrência disso, é importante assinalar que em matéria ambiental geralmente os fatos mais relevantes primeiro acontecem na sociedade internacional, para após, materializam-se nos ordenamentos jurídicos nacionais para finalmente ser executados em contextos locais.

O direito ambiental como emergente cataloga-se como um Direito Humano de terceira geração, já que sua natureza coletiva responde do plano axiológico ao valor da solidariedade, de modo a mitigar a eminência dos danos que impactam a sociedade, não apenas no aspecto ambiental, como no econômico e social a fim de inferir que tudo que se relaciona com o ambiente reflete na dimensão individual e coletiva, portanto, sua proteção deve se vincular aos fins essenciais do Estado.

Desde a conferência de Estocolmo ficou claro que "o meio ambiente é o conjunto de recursos que podem ser explorados com racionalidade econômico-social e ambiental, para alcançar objetivos de desenvolvimento válidos no longo prazo". O interessante é ver que a partir de estas premissas começam a ser estruturados os planos de desenvolvimento dos países e neste aspecto pode ate ser questionada a soberania nacional já que no sentido tradicional a soberania e vista como a autonomia dos povos para autodeterminar-se e proferir sua própria normatividade, mas fica claro que quando se fala de bens jurídicos protegidos pelo direito ambiental, as normas e os lineamentos do planejamento e a gestão dos recursos naturais transcende do conceito inicial de soberania, tal como será discutido no capítulo segundo.

Embora a preocupação com o direito ambiental se inicie nos anos 70, é a partir da década de 90 que suas leis serão legitimadas e terão efetividade. Essa institucionalização do direito ambiental tem resultados especialmente após o processo da Constitucionalização de tal direito, sendo exemplos disso a Constituição colombiana de 1991, a Constituição brasileira de 1988 e a Constituição espanhola de 1978. Outro exemplo dessa institucionalização do direito ambiental é a criação de órgãos públicos como o Ministério do Meio Ambiente, para a inspeção, vigilância e controle sobre o uso e aproveitamento dos recursos naturais, e autoridades exclusivas para outorgar licenças ambientais. Com isso, cada vez mais se legitima a validez e eficácia do direito ambiental, de modo a ganhar espaço como ramo autônomo do direito. 
Neste cenário a fonte eólica se desenvolve juridicamente a partir de todos os princípios e postulados do direito ambiental, como se evidenciará no decorrer deste capítulo. Já que criar um suporte jurídico para o desenvolvimento de fontes renováveis de energia é um instrumento que viabiliza a consecução de alguns de alguns dos objetivos ambientais por sua importante contribuição contra o efeito estufa, entre outros fins do desenvolvimento sustentável, tal como analisado no capítulo terceiro.

\subsubsection{Recursos naturais como bens comuns da humanidade}

Os recursos naturais são bens coletivos da humanidade e justamente por isso seu tratamento jurídico supera o âmbito da soberania do Estado e despoja o tradicional conceito de propriedade privada. As relações entre recursos naturais e a sociedade fazem alusão a uma renovada relação jurídica e econômica, com a finalidade de atingir um novo patamar de responsabilidade social e ambiental. Os bens comuns, dentre os quais se encontram muitos bens da categoria ambiental, apresentam uma particularidade da forma de gestão e brinda novas possibilidades de associatividade e gerenciamento pela sua co-propriedade intrínseca; que vai além da classificação da teoria econômica como propriedade privada e propriedade pública, pois são bens comuns (OSTROM, 1990).

Quando se centra a analises dos recursos naturais para categorizar lhes e impuser Ihes um regime jurídico desde o discurso sobre a titularidade fica insuficiente para explicar seu alcance. Certamente, o interesse geral que alberga um bem comum como é o médio ambiente, leva a exigir uma maior eficácia na aplicação do direito ambiental, entendendo que esse interesse geral é prevalente inclusive sobre outros bens jurídicos (MOSSET; HUTCHINSON; DONNA, 2011). Essa relação jurídica de prevalência do médio ambiente, como bem coletivo, sobre outros bens encontra justificativa tanto na função social quanto na função ecológica da propriedade.

Um exemplo claro da função ecológica da propriedade é enunciado por Delgado de Miguel nos seguintes termos: "o catalisador que transforma o regime normal de domínio em algo distinto que chega a configurá-lo e lhe dar uma forma bem exata: não a que projeta o titular sobre sua coisa, senão a forma que ela adquire pelo uso mais adequado ao meio ambiente" (tradução própria). Isso permite extrair o predomínio 
do meio ambiente como bem jurídico sobre outro bem jurídico, como a propriedade privada.

Nessa fase o direito ambiental passa do antropocentrismo, centrado em termos utilitaristas, com a exploração dos recursos naturais, para uma fase biocêntrica, em que a utilização racional destes recursos se encontra subordinada a sua capacidade ambiental ${ }^{1}$. Ou seja, que a utilização de cada recurso natural se encontra limitada a sua própria existência e que se tratando de recursos renováveis, sua gerência adequada esta condicionada pela sua capacidade para ser empregado no futuro, para o qual se requer planos de gestão ambiental e constante monitoramento.

É de observar que a visão biocêntrica do direito ambiental aproxima-se mais à teoria da justiça ambiental como paradigma de distribuição dos recursos, tendo como norte o componente sistêmico do meio ambiente, no qual interatuam todos os recursos naturais (SCHLOSBERG, 2007). Igualmente, se encontram como objetivos do direito ambiental a conservação da biodiversidade e a promoção do desenvolvimento sustentável (MACIAS, 1998).

Para tanto, o próprio sistema jurídico do direito ambiental está designado a desenvolver o conteúdo axiológico do desenvolvimento sustentável, o qual vai além da conservação, prevenção e compensação dos danos ambientais.

A distribuição de um bem jurídico de natureza social, como o meio ambiente, deve ser dada de forma igualitária para que se cumpra a aplicação prática da justiça. Neste ponto, recorre-se a visão de Rawls sobre a justiça, também compartilhada por Nino, segundo a qual os princípios de justiça estabelecem critérios para outorgar direitos e obrigações nas instituições básicas da sociedade, para adequarem a distribuição dos benefícios e cargas de cooperação social (NINO, 2007).

Desta feita, os bens jurídicos que tutelam o direito ambiental rompem as concepções clássicas da ciência jurídica, como por exemplo, a de que a titularidade de um direito subjetivo somente recai nos seres humanos. Distante de tal exemplo, o direito ambiental pressupõe que os recursos naturais em si mesmos podem ser sujeitos de direito. Isso muda a concepção da relação sujeito e objeto, tão cara à ciência jurídica.

\footnotetext{
${ }^{1}$ Entendendo por capacidade ambiental de um recurso natural a possibilidade de exploração, sem afetar sua sustentabilidade ou capacidade de auto-regeneração.
} 
Assim, o direito ambiental incorpora um dinamismo particular na ciência jurídica que reivindica uma revisão hermenêutica. Isso é o que se reconhece no âmbito jurídico como paradigma ambiental, o qual permite inferir que "a temática ambiental implica em uma mudança na lógica jurídica clássica e uma mutação axiológica do ponto de vista do direito em general" (CAFFERATA, 2004).

Neste aspecto, o direito ambiental responde "à busca de harmonia, de uma ordem justa em nosso entorno, de uma justiça em nossas instituições e em nossas sociedades e de ações justas em nossas vidas; são diferentes riachos que alimentam um mesmo rio: o da justiça ecológica, integradora e relacional, que atende à pessoa e a transcende com o intuito de envolver o entorno e abarcar presente, passado, futuro" (VEGA; ANGUITA, 2011).

Com relação ao bem jurídico pelo qual propende o direito ambiental, os autores argentinos em concordância com a perspectiva biocentrista consideram que "o bem jurídico tutelado em matéria ambiental é a vida, o sujeito passivo de todo dano ambiental é a humanidade, o bem afetado é o planeta e a transcendência é universal. Se afeta o presente, mas sem dúvida as mais graves consequências serão para as futuras gerações" (PIERINI; LORENCES; COMPARATORE, 2007).

No que tange ao meio ambiente como bem jurídico, a Corte Constitucional da Colômbia tem expressado o seguinte:"O meio ambiente do ponto de vista constitucional, envolve aspectos relacionados com a gestão, uso, aproveitamento e conservação dos recursos naturais, o equilíbrio dos ecossistemas, a proteção da diversidade biológica e cultural, o desenvolvimento sustentável e a qualidade de vida do homem entendida como parte integrante desse mundo natural [...]" (tradução própria). A proteção do meio ambiente tem adquirido na Constituição Política um caráter de objetivo social, relacionada adicionalmente com a prestação de serviços públicos, a salubridade, os recursos naturais como garantia da sobrevivência das gerações presentes e futuras, sendo compreendida como uma prioridade dentro dos fins do Estado e como reconhecimento do dever para com a qualidade de vida dos cidadãos ${ }^{2}$.

A tecnologia utilizada para a geração de energia eólica se encontra alinhada com o aproveitamento eficiente dos recursos naturais, recursos estes que devem ser tra-

\footnotetext{
${ }^{2}$ Corte constitucional Colombiana. Sentença T-453 de 1998. Magistrado: Alejandro Martínez Caballero.
} 
tados como bens comuns, segundo o exposto. Sua utilização complementa dois fins do direito ambiental, cujo valor supremo é a solidariedade: o primeiro fim remete a materialização da energia eólica e a utilização dos recursos do vento com a intenção de aperfeiçoar seu potencial para satisfazer necessidades humanas e gerar uma externalidade social positiva na medida em que contribui com novos empregos (MATTMANN; LOGAR; BROUWER, 2016); o segundo fim está orientado para a mitigação dos danos ambientais vinculados a geração de energia quando comparada a fontes convencionais (ZERRAHN, 2017). Dessa última perspectiva finalística pode se inferir que o direito ambiental encontra sua razão de ser no desenvolvimento sustentável.

\subsubsection{Direito Ambiental e sociedade internacional perante a transição do setor elétrico}

Os países, além de satisfazer os interesses e necessidades de seus nacionais, estão tradicionalmente focados em potencializar sua participação na sociedade internacional, ainda que esse papel tradicional seja discrepante de sua realidade perante o cenário globalizado.

No processo de transição do setor elétrico da energia convencional para as energias renováveis também se beneficia da articulação dos Estados e da sociedade internacional para desenvolver as instituições do direito ambiental. Claramente os sujeitos jurídicos da sociedade internacional tem sua influência no processo decisório dos mecanismos para desenvolver as energias renováveis, condicionado pelos bens e serviços que possa oferecer, e sua capacidade de resposta às expectativas dos modelos de desenvolvimento sustentável. Não obstante, sempre o Estado detém a titularidade sobre os bens públicos, dentre os quais se contam os recursos naturais de seu território. Em decorrência, em exercício da sua soberania os Estados tem a possibilidade de arbitrar em última instância sobre as prioridades em relação ao uso e exploração de seus recursos naturais, mas também devem responder aos requerimentos da sociedade internacional em termos ambientais (ROJAS, 2007).

É na sociedade internacional onde são gestadas as medidas específicas sobre o cuidado e a proteção do meio ambiente. Os mecanismos de proteção requerem abranger as necessidades particulares dos diversos Estados que, em exercício da sua soberania, aderem aos tratados internacionais em matéria ambiental. Contudo, 
observa-se que o relacionado ao cuidado e preservação do meio ambiente transcende o plano internacional, já que existe uma conexão entre os fatos que prejudicam o uso e a exploração dos recursos naturais; embora na jurisdição interna de cada Estado sejam resolvidos os danos ou prejuízos ocasionados aos recursos naturais, sem prejuízo de que possam ser coordenadas ações de cooperação internacional.

A partir dos compromissos ambientais que são gestados na sociedade internacional foram desenvolvidos aspectos transcendentais para o direito ambiental, o que implica uma "relação necessária entre a proteção ao ambiente e o usufruto dos direitos humanos junto a consciência da interdependência entre proteção do ambiente e desenvolvimento econômico" (ROJAS, 2007) (tradução própria).

Igualmente, parte do avanço em matéria ambiental decorre da definição de instituições no nível internacional e sua posterior consolidação nos níveis nacional e local, onde se pode reivindicar a segurança jurídica sobre a proteção dos bens ambientais. Certamente, perante fenômenos tais como uma iminente mudança climática, contaminação atmosférica, afetação da biodiversidade e o desgaste da camada de ozônio, é indispensável trabalhar nos planos de desenvolvimento nacionais e locais para que se ganhe efetividade na gestão dos recursos seguindo os parâmetros do desenvolvimento sobre a base da sustentabilidade. O qual acarreia que os países adotem medidas de controle e qualidade na gestão dos recursos naturais, o que atinge as esferas sociais, econômicas e ambientais. Isso pode ser extrapolado a o que acontece com a energia eólica, na medida em que além de ter uma importante contribuição à redução do efeito estufa, também apresenta externalidades positivas no social e econômico (MATTMANN; LOGAR; BROUWER, 2016).

Orientar a política energética à transição às energias renováveis é uma questão de responsabilidade dos países para com o princípio de desenvolvimento sustentável. Contar com uma cota de energia limpa é obrigação internacional dos Estados ante sua responsabilidade ambiental, que já não é uma questão interna, de mero policiamento ambiental (BIRNIE; BOYLE, 1992). O dano ambiental pode ser atribuível à ausência de gestão ou a uma gestão ineficiente do Estado e nesse sentido, o Estado em sua atuação está submetido aos princípios de legalidade e justiciabilidade. Os Estados também estão sujeitos ao princípio de responsabilidade, mas este deve ser conferido por meio de convênios internacionais (KISS, 2005). O desenvolvimento da legislação 
ambiental tem possibilitado a boa governança dos bens ambientais, de modo a levar aspectos da responsabilidade dos Estados a um novo patamar internacional.

O tema das energias renováveis esta imersa na categoria de responsabilidade internacional dos Estados, na medida em que a ênfase na diversificação das matrizes elétricas constitui uma obrigação perante a sociedade internacional. As fontes renováveis representam segurança e vantagens de complementaridade para os momentos de crises elétricas, mesmo que a urgência na transição elétrica leve a adotar medidas que tenham consequências adversas em longo prazo, quando não são considerados fatores como os riscos regulatórios e a capacidade do País para honrar seus compromissos jurídica e economicamente.

A transição energética é uma prioridade, mas deve ser feita de maneira a considerar os avanços no ordenamento jurídico de forma incremental, é dizer incorporando progressivamente as modificações e ajustes precisos para o desenvolvimento das decisões institucionais adotadas conforme à racionalidade analítica (NORTH, 1990). Ainda que as energias renováveis demandem um impulso financeiro forte na fase de implementação, tal esforço é justificado pelo bem que representa a contribuição com a prevenção e mitigação das externalidades negativas presentes no setor elétrico, diretamente vinculadas aos danos ambientais.

\subsubsection{Direito ambiental e economia circular e sua relação com a energia eólica}

O compromisso com o crescimento verde acarreta uma série de ações concretas o qual requer intervenção do poder executivo e do legislativo para materializar os objetivos de avanço ao crescimento sustentável e de baixo carbono. A consolidação de um crescimento sustentável visa à redução da vulnerabilidade dos recursos naturais, perante os riscos de desastres naturais e perante a mudança climática, e finalmente redunda em prol do melhoramento da qualidade ambiental e da proteção do uso sustentável do capital natural, incrementando sua resiliência.

Decidir a intervenção e acompanhamento do direito ambiental, em termos coercitivos para limitar o uso e exploração dos bens ambientais, requer de razoabilidade prática; entendida como o instrumento para eleger os meios mais eficazes para conseguir os fins do assunto que se esta regulando (BYDLINSKI, 1982). Quando a intervenção 
via direito ambiental seja coerente com o ordenamento jurídico necessariamente provocam um efeito no aspecto de desenvolvimento econômico, permitindo que desde a racionalidade prática do direito se projete a materialização da economia circular, que da consistência ao desenvolvimento sustentável.

Porém, uma das maiores críticas que o direito ambiental recebe é a ponderação da dimensão econômica que costuma ter um enfoque preponderantemente orientado pelo custo benefício, quando deveria ter maior ênfase na prevenção do dano ambiental. Em termos utilitaristas a aplicação de instrumentos econômicos na ponderação das vantagens e desvantagens ambientais das decisões políticas e legislativas, em alguns casos pode ser evidenciada quando se analisam as políticas públicas. Por exemplo, no caso dos incentivos para a energia eólica, estabelecendo metas para incrementar a capacidade instalada o que representa um incremento de renováveis na matriz elétrica e uma consequente diminuição de emissões de $\mathrm{CO}_{2}$. Um caso contrário acontece quando se incrementa a visão utilitarista, e se estabelecem cotas aos direitos de uso e exploração dos recursos naturais, mas sem exista uma política clara em matéria de compensação ambiental.

A dificuldade para aplicar os instrumentos econômicos os bens ambientais está dada por uma série de variáveis como as diversas competências institucionais que tem que intervir para sua estruturação; os custos do levantamento de informação; a necessidade de estabelecer complexos processos distributivos ou de alocação de recursos; a complexidade dos processos políticos; a medição dos impactos ambientais com suas múltiplas fontes de impacto, assim como aspectos de sustentabilidade fiscal (VASQUEZ, 2007)

Da mesma forma, para efeitos práticos de implementação do método econômico na ponderação jurídica ambiental, as ações específicas estão permeadas pela inovação e tecnologia. Em sentido estrito, isso materializa a visão de desenvolvimento sustentável por meio da otimização dos recursos. No caso da energia eólica, claramente quando se desenham as políticas públicas para incrementar sua participação na matriz elétrica é relevante considerar que, graças aos avanços tecnológicos vai ser possível auferir ganhos de eficiência na geração o que repercute na remuneração dos investidores na vigência dos contratos. Os ganhos econômicos decorrentes da eficiência tecnológica certamente devem estar previstos nas decisões de planejamento de 
expansão de capacidade instalada para energia eólica. Porque embora não se saiba qual será o avanço significativo em eficiência, sim podem estabelecer-se possibilidades de reforma nas políticas de incentivos quando advenham alterações tecnológicas que reportem eficiência nos custos da operação dos parques eólicos.

\subsubsection{Reflexão sobre a energia eólica desde a perspectiva da justiça ambiental}

O meio ambiente como categoria jurídica passível de proteção apresenta divergências doutrinárias quanto ao seu conteúdo e alcance. De fato, existem três posturas para avaliar juridicamente o conceito de meio ambiente: a tese restrita sobre $o$ meio ambiente propõe que se protejam os recursos hídricos e eólicos correspondentes à primeira fase do desenvolvimento do direito ambiental, pois estes recursos são ponderados como bens indispensáveis para o homem; a tese intermediaria, inclui o âmbito de proteção ao ambiente biológico de modo a expandir o espectro do direito ambiental aos recursos de fauna e flora; a tese ampla, que tem origem na Conferência do Rio de Janeiro de 1992, busca a proteção dos recursos naturais incluindo o meio artificial, que fora construído pelo homem como ambiente social (ABIDIN; LAPENTA, 2007).

As teses supracitadas constituem a abertura, o fundamento jurídico e fático para o avanço da energia eólica por sua importante contribuição com o desenvolvimento sustentável e o que este representa para a promoção e incentivos às energias renováveis. Não obstante, existe no ordenamento jurídico algumas normas sobre proteção ambiental que devem ser respeitadas pelos investidores da energia eólica sobre paisagismo, normas sobre contaminação auditiva, proteção da fauna e para a ponderação das externalidades positivas e negativas associadas à implementação da energia eólica (MATTMANN; LOGAR; BROUWER, 2016). Igualmente, segundo a rigidez ou flexibilidade da normatividade nacional no procedimento de licenciamento ambiental, para a atividade econômica de geração de energia inclusive a partir de fontes renováveis, pode ser ocasionada uma interdição do processo de transição energética.

O direito em sua condição disciplinadora da sociedade promove a adoção de normas de acordo à razoabilidade prática que leve à satisfação dos fins políticos, econômicos e sociais. Essa razoabilidade prática quando vinculada ao direito ambiental se 
vislumbra no dever de proteger o meio ambiente e em políticas que promovam a prevenção de danos ambientais, o que maximiza a consistência do desenvolvimento sustentável e se alinha com os objetivos de justiça material. A tarefa da justiça ambiental inicia pela consolidação de um ordenamento jurídico com o compromisso de satisfazer os fins do desenvolvimento sustentável. Mas a normatividade ambiental que esta emergindo tem a particularidade de requere alinhamento com as leis próprias da natureza, com a ecologia e com os bens ambientais. Essa condição do direito ambiental alude a não esta isento de imprecisões terminológicas ou dificuldades hermenêuticas no seu processo de consolidação, o que pode também trasladar-se à materialização da justiça ambiental, que é em última instancia a eficácia do direito.

A aludida eficácia do direito em termos ambientais, no que tange às energias renováveis, encontra-se condicionada pela sua capacidade de articular-se com outras áreas do conhecimento como a engenharia, já que a normatividade deve ser desenhada em função dos avanços em matéria tecnológica e à inovação. Certamente os avanços tecnológicos não somente podem contribuir com o meio ambiente, senão que também representam ganhos econômicos que devem ser considerados ao momento de pensar nos incentivos. No caso da energia eólica isso pode ser evidenciado quando se ganha eficiência técnica e aperfeiçoa-se a capacidade de geração de energia dos aerogeradores ou se ganha maior capacidade de armazenamento das baterias. Não obstante também a interação entre o direito e a engenharia também pode representar um paradoxo de difícil solução, mesmo quando procuram fins similares enquanto à proteção do meio ambiente.

Como afirma FINNIS: "Tome como premissa ao menos uma das razões básicas para a ação e siga para o ponto que você de alguma forma trouxe sobre a instantaneidade da necessidade em ação. Não aja sem um objetivo". A partir deste critério finalístico é pertinente instrumentar os objetivos do direito ambiental, adotando parâmetros tais como o princípio de contaminador pagador, a eco-eficiência, a capacidade de carga ${ }^{3}$, que ponderam qualitativa e quantitativamente os limites de exploração dos recursos naturais. Certamente resulta crucial contar com critérios para ponderar a capacidade que têm os ecossistemas para suportar o contínuo crescimento no consumo

\footnotetext{
${ }^{3}$ Segundo PEREZ BUSTAMANTE, este conceito foi definido pelos biólogos como a máxima população de espécies que pode ser suportada indefinidamente em um habitat definido... Quando o nível máximo da população é excedido, a base do recurso declina, e tempo depois aparece a poluição
} 
e a poluição (PEREZ, 2007), já que com base nele pode ser determinada a justiça distributiva aplicável aos bens jurídicos ambientais, que convidam à gestão sustentável ${ }^{4}$ e cujo uso e exploração ocasionam rivalidade, e também é aplicável quando se requerem critérios de seletividade na alocação de incentivos.

Portanto, é fundamental dotar os sistemas jurídicos de uma razoabilidade prática norteada pelos conceitos próprios da sustentabilidade, que sirvam de suporte na estruturação de política ambiental e política energética, coerentes com o ordenamento jurídico considerado em sua universalidade ${ }^{5}$. De tal sorte que possam ser auferidos maiores benefícios da normatividade ambiental em matéria de energias renováveis o que se converte em maior eficácia dos objetivos ambientais. Isso, por sua vez se reverte, no caso das políticas para energia eólica, na plausibilidade de uma programação e implementação mais eficiente e eficaz das decisões de inserção desta fonte de energia.

A dificuldade em abordar o meio ambiente como bem jurídico é acentuada quando se questiona a abordagem antropocêntrica como eixo da proteção jurídica, entendendo o homem como o elemento mais relevante dentro de seu entorno. Por outra parte se propõe a preponderância da visão biocêntrica no direito ambiental, na qual se propende pelo cuidado e preservação dos recursos naturais considerados em se mesmos (VEGA; ANGUITA, 2011).

O direito ambiental tem sido consolidado a partir de instrumentos internacionais, contudo, sua validez está condicionada aos processos legislativos e regulatórios nacionais e locais. Assim, o efeito jurídico que se requer em sua prática é de caráter local, ainda que as principais iniciativas em prol do ambiente sejam gestadas no âmbito nacional e internacional. Do anterior infere-se a importância do direito ambiental internacional para alcançar uma justiça ambiental no nível local com efeito internacional devido a que "os atentados ao meio ambiente ainda quando ocorrem em um entorno local, repercutem no ecossistema global” (ROJAS, 2007) (Tradução própria).

Não obstante, é importante advertir que existe uma demarcada influência do direito

\footnotetext{
${ }^{4} \mathrm{~A}$ gestão sustentável leva a desenvolver critérios e metodologias para a avaliação das decisões da administração pública e dos particulares que exploram os recursos naturais.

${ }^{5} \mathrm{O}$ termo universalidade do ordenamento jurídico é utilizado no sentido de plenitude do ordenamento jurídico, o que lhe da a condição ordenada de sistema jurídico, que permite que seja um sistema complexo e acabado de acordo à explicação oferecida pelo professor Gregorio Peces- Barba.
} 
ambiental internacional no âmbito local e em aras da eficácia do direito ambiental tem sido desenvolvido o princípio de rigor subsidiário. Esse princípio expressa que as regulações nacionais são um padrão mínimo que as autoridades ambientais regionais e territoriais devem cumprir, já que as medidas da polícia ambiental poderão se tornar mais rigorosas, não mais flexíveis (BARRERA, 2006). O alcance do princípio de rigor subsidiário radica justamente na necessidade de levar justiça ambiental às entidades territoriais em que se apresentam as consequências adversas do uso indevido dos recursos naturais.

Salienta-se que o enfoque teórico do direito ambiental encontra afinidade com a tese ampla proteção ao meio ambiente, pois entende que não são componentes isolados que correspondem a um sistema, pelo contrario esta composto por múltiplas partes que interatuam para manter o equilíbrio da vida sobre o planeta (TOMAS, 2007). Portanto, a resposta do direito mediante a proteção e tutela do meio ambiente deve ser integral, na medida em que se propenda pela prevenção, mitigação e compensação do dano que possam vir a sofrer os recursos naturais, fazendo maior ênfase no caráter preventivo. Neste caso, requere-se previamente ter identificado os riscos potenciais e sobre tal base efetuar um trabalho de planificação e gestão.

A intervenção do direito tem como fim prevenir e resolver os conflitos que surgem na sociedade arbitrando pela convivência pacífica, mas para isso em exercício da soberania que tem o Estado ordena o proíbe coativamente algumas ações ${ }^{6}$. Mas na formulação de normas que sejam coerentes com os requerimentos de uma sociedade complexa e dinâmica é importante integrar à técnica jurídica os aportes de outros ramos do conhecimento como a biologia, química, engenharia ambiental. Nestas áreas do conhecimento permitem diagnosticar o estado atual dos recursos naturais e propõem técnicas para uma gestão consciente. Adicionalmente, graças à interação do direito com as outras áreas do conhecimento encontram-se os dados específicos, a partir dos quais é possível determinar as ações preventivas, compensatórias e sancionatórias sobre os bens ambientais. Esta última tarefa é efetuada pelo direto desde a função da dogmática jurídica ${ }^{7}$ e graças a sua peculiaridade de dotar de conhecimento

\footnotetext{
${ }^{6}$ Esta interpretação tem origem no conceito de "dever jurídico que acarreta necessariamente a existência de um mandato cujo cumprimento se apoia na ameaça de infligir um dano a quem o desconheça". PECES- BARRA

${ }^{7} \mathrm{~A}$ dogmática jurídica em palavras de SANTIAGO NINO é a modalidade de ciência jurídica caracterizada por algumas atitudes ideológicas e ideais racionais respeito ao direito positivo, por determinadas
} 
cientifico ao direito que sirva de base para sua interpretação e aplicação.

Antes de abordar a teoria da justiça ambiental é pertinente assinalar que o conceito de justiça do qual se ocupa o direito ambiental abarca não apenas a visão ética de justiça distributiva e reparadora, como encontrada no pensamento aristotélico, mas ainda uma visão de justiça própria das teorias contratualistas, como demonstra Rawls ao encontrar justiça nos valores de equidade e imparcialidade.

Nesta mesma linha conforme diz Hume: "A justiça tem sua origem unicamente no egoísmo e na limitada generosidade dos homens, junto aos escassos recursos que a natureza tem disposto para suas necessidades" (HUME, 2001). A partir desta ideia pode ser contrastada como critério valorativo de justiça a relação homem-natureza, e complementar o ordenamento jurídico com normas que abranjam o conteúdo da justiça ambiental.

Salientar-se que o meio ambiente começa a ser ponderado do ponto de vista jurídico a partir da conferencia de Estocolmo de 1972, desde então se começa a buscar soluções jurídicas para a crescente problemática ambiental em torno aos efeitos adversos e a dificuldade de renovação dos recursos naturais. Adicionalmente foram vinculados os conceitos de desenvolvimento e meio ambiente, entendendo que são conceitos que não se podem cindir, quando se esta na procura da justiça ambiental. Considera-se também que "dentre os grandes ganhos da Conferência de Estocolmo se destacam a ênfase ao estreito vínculo existente entre meio ambiente e desenvolvimento, tema retomado posteriormente pela Conferência do Rio de Janeiro, de modo a constituir seu eixo temático principal a união entre o meio ambiente e os direitos humanos, discussão que dominou a evolução do direito ambiental na década seguinte" (URIBE; CARDENAS, 2010).

A análise do conceito de justiça de Rawls é fundamental neste ponto da pesquisa, pois ele lança parâmetros para se estabelecer um conceito de justiça que requer uma situação de conflito mediante a qual se reparte algo considerado vantajoso ou desvantajoso. Mas para estabelecer esses parâmetros de justiça deve preceder um vinculo entre o direito e o poder de sua criação que radica no Estado. Neste sentido Habermas indique que "da constituição original e do estrelazamento conceptual de direito e funções que cumpre em relação a ele e por técnicas de justificação das soluções que propõe. (NINO, 2007) 
poder político resulta, uma ampla necessidade de legitimação, como é, a necessidade de canalizar termos jurídicos, o poder estatal da sanção, organização e execução" (HABERMAS, 2010).

\subsubsection{Desenvolvimento sustentável e a eficácia do direito ambiental}

O início do desenvolvimento sustentável constitui o próprio objeto de estudo do direito ambiental, que perante a problemática ambiental atual requer a imprescindível intervenção da ciência jurídica, para concretizar a harmonização entre homem e natureza. O direito ambiental no processo de consolidação de seu objeto de estudo visa regular as ações concretas que permitam materializar os objetivos do desenvolvimento sustentável; e satisfazer a expectativa social do direito como elemento organizador da sociedade. Sem descuidar o pressuposto da eficiência do direito segundo a qual "a ordenação da simples coexistência dos seres humanos e a obtenção de objetivos comuns são elementos que explicam a natureza social do direito" (PECES-BARRA, 1987).

Um dos fatores que se destacam para a consolidação do direito ambiental fora a incorporação do conceito de desenvolvimento sustentável, elaborada em 1987 no informe de Brundtland (ONU, 1987). Assim, o desenvolvimento sustentável é erigido como princípio orientador da legislação ambiental e como diretriz fundamental para a política ambiental internacional, nacional e local; de forma a iniciar um novo capítulo para o desenvolvimento econômico. Tal princípio de desenvolvimento sustentável materializa a concepção de justiça social como descrita na visão de Rawls, pois todos os seus elementos tornam plausíveis o objetivo a edificação de uma sociedade justa.

O conceito de desenvolvimento sustentável estabelecido pela comissão de Brundtland é o seguinte: "o desenvolvimento que satisfaz as necessidades da geração presente sem comprometer a capacidade das gerações futuras ao suprir suas próprias necessidades". Daqui se desprende o compromisso intergeracional que existe em torno do cuidado e preservação do meio ambiente, junto das seguintes estruturas vinculadas a seu efetivo desenvolvimento: erradicação da pobreza, fome zero, boa saúde, bem-estar, educação de qualidade, igualdade de gênero, água limpa, saneamento básico, energia acessível e limpa, emprego digno, crescimento econômico, 
indústria de inovação e infraestrutura, cidades e comunidades sustentáveis, redução de desigualdades, produção e consumo responsáveis, ações pelo clima, ações pela vida submarina e pela vida de ecossistemas terrestres, paz, justiça e instituições sólidas que formem alianças para cumprir estes objetivos ${ }^{8}$.

O desenvolvimento sustentável, incluí uma dimensão social que se consolida na participação ativa dos cidadãos nas decisões que os afetam, inclusive no aspecto pluralista do modelo de Estado contemporâneo que, além de ser Estado de Direito, tenciona ser Estado Social de Direito. Na dimensão econômica se considera correto impulsionar o crescimento de atividades econômicas que devem ser desempenhadas com responsabilidade social e ambiental, de modo a efetuar o aproveitamento sustentável dos recursos naturais.

Nesta ordem de ideias o desenvolvimento sustentável em sua dimensão deontológica é considerado a essência do direito ambiental, sendo que cada um dos objetivos determinados no marco das Nações Unidas representa uma meta regulatória, tanto no âmbito doméstico como na sociedade internacional. Adicionalmente, esse é um conceito que faz referência à necessidade de levar a cabo uma exploração racional dos recursos naturais de forma que não se chegue a os esgotar, o que exige considerar os critérios de solidariedade e interdependência. A razoabilidade do desenvolvimento sustentável cobra importância para os efeitos práticos e para a distinção entre os recursos renováveis e não renováveis, com o intuito de adequar-lha à conservação para o benefício das gerações de hoje e do futuro (ROJAS, 2007).

Destaca-se o objetivo de manter o equilíbrio é encaminhar a ação política estatal e internacional para a realização do desenvolvimento sustentável como bem superior comum a todos os povos, mas este objetivo deve ser abordado pelo direito. Assim, deve-se abordar a técnica jurídica que cuida a legitimidade, validez e eficácia de normas ambientais, dentre elas as relativas a energias renováveis. Um dos acertos que deriva dessa perspectiva se encontra na seleção adequada de instrumentos relevantes para analisar com rigor científico e crítico a problemática ambiental e suas possíveis soluções no plano político, jurídico-normativo (PÁEZ; RODRIGUEZ, 2012), que deve encaminhar decisões racionais diante da ameaça do meio ambiente. Desta ma-

\footnotetext{
${ }^{8}$ Comisión Mundial del Medio Ambiente y del Desarrollo, Nuestro futuro Común, Madrid, Alianza Editorial, 1989
} 


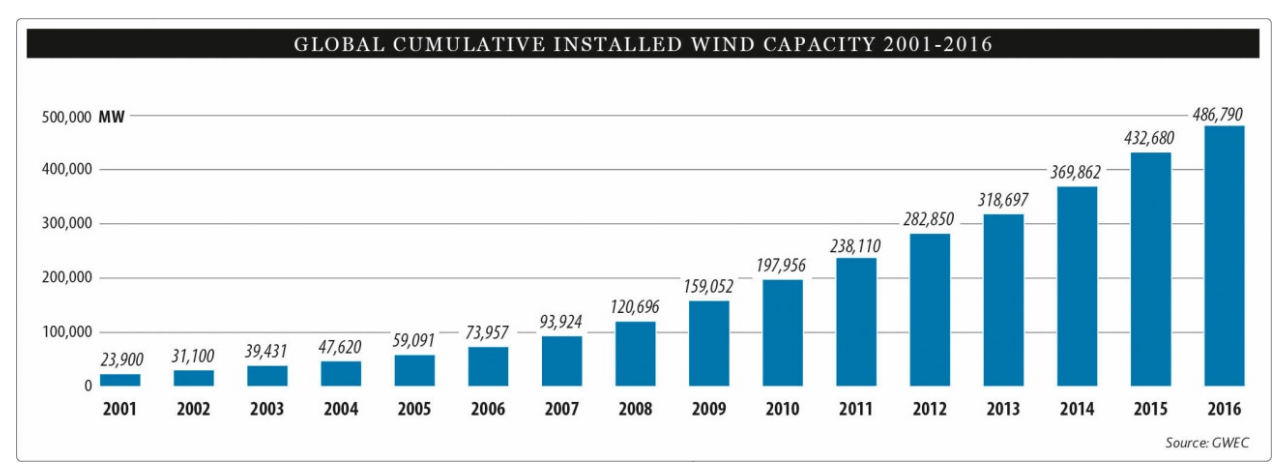

Figura 1 - Evolução mundial da capacidade instalada de energia eólica

neira, para a aplicação prática do conceito de desenvolvimento sustentável é preciso pressupor que se está em uma condição de dificuldade na alocação de recursos naturais, sociais e econômicos para a qual se requer uma decisão racional e proporcional que admita sua aplicabilidade.

As considerações sobre o processo de Constitucionalização do direito ambiental a partir da inclusão do conceito de desenvolvimento sustentável em política econômica leva implicitamente a interdisciplinaridade, que vai além do âmbito jurídico e inclui conceitos como: ambiente saudável, qualidade de vida, função ecológica da propriedade privada, função ecológica da empresa, recursos naturais, dentre outros. Esse conjunto de bens jurídicos também são ponderados juridicamente e devem "ser interpretados na relação com as ciências naturais e as ciências sociais" (AMAYA, 2016) (Tradução própria).

\subsubsection{A Energia eólica e o direito ambiental}

A evolução da capacidade instalada de energia eólica no mundo passou de 23,900 MW no ano de 2001 para 489,790 MW em 2016, reportando um crescimento anual durante este período de mais de $12 \%$ ao ano. Com a expectativa de crescimento de mais de 20\% para o ano 2021 por meio da operação dos próximos parques eólicos, a capacidade instalada de energia eólica alcançará $8 \%$ da matriz energética mundial (CONCIL, 2017), tendo como referencia os dados da figura 1.

Outro dos motivos para impulsionar a energia eólica e aplicar o regime jurídico de direito público é o de que esta apresenta uma excelente complementaridade para as demais fontes de energia convencional. Especificamente a energia eólica apresenta 
um excelente comportamento em quanto à complementaridade com a energia hidráulica quando esta última é a principal fonte de eletricidade, tal como acontece em países como Brasil e Colômbia, nos períodos da seca, já que a densidade do vento é maior e permite efetuar um ajuste sazonal entre as fontes hidráulica e eólica pelas oscilações regulares da natureza e a possibilidade de previsão de seu comportamento segundo a época do ano.

\subsubsection{Teoria dos Bens e Serviços Públicos aplicados à Energia Eólica}

Os recursos naturais e energéticos, como bens passíveis de categorização sob o conceito de interesse público, requerem uma intervenção legislativa como instância inicial para que ganhem vida jurídica e possam ser protegidos e desenvolvidos nas esferas da administração pública e na jurisdição. A intervenção legislativa requer planejamento, promovido por fatores sociais políticos, jurídicos e econômicos e posteriormente atravessa-se uma fase de discernimento para decidir a necessidade e a pertinência da intervenção (CASALS, 1989).

No caso particular do recurso do vento projetado como potencial energético suscetível de exploração têm situações novas que podem chegar a gerar discrepâncias perante as quais o direito não pode estar ausente. A energia eólica devido a sua rápida proliferação requer tratamento jurídico desde a metódica da legislação; este fenômeno acarreia ponderação jurídica do recurso do vento e a possibilidade de analisar-lho sob a perspectiva das categorias jurídicas de bens e serviços públicos. Esta última análise depende da capacidade de estabelecer o regime aplicável ao vento e posteriormente à energia eólica e tornar-lhos objetos jurídicos suscetíveis de projetar-se em relações jurídicas.

O fato de projetar uma matriz elétrica limpa merece intervenção do poder político para depois plasmar-lho na normatividade, pois contar com recursos renováveis é uma questão fundamental dentro da política ambiental de um país, o que torna de interesse público todos os recursos que contribuem para a consolidação do desenvolvimento limpo. Embora o interesse público seja um princípio jurídico indeterminado no contexto do Estado social e democrático de Direito, deve-se atribuir a ele a funcionalidade diretiva própria do Estado contemporâneo, materializando-o em políticas 
públicas, leis e regulamentações, entre as que se encontram as relativas às energias renováveis.

A força dos ventos para produzir energia é um bem inesgotável e abundante, mesmo assim não todos os territórios têm o comportamento do vento, apto para gerar energia elétrica. Os aspetos meteorológicos condicionam a densidade e a velocidade do vento, que por sua vez impacta no fator de capacidade da turbina eólica (WANG; HU; MA, 2016).Estas questões eminentemente técnicas ajudam a determinar economicamente a distribuição dos territórios aptos para os parques eólicos do qual decorrem políticas especificas para sua adjudicação e, pelo tanto, arranjos normativos que reflitam parâmetros de justiça distributiva.

Em princípio, poderia ser considerado que a utilização do vento para gerar energia não apresenta rivalidade alguma, entre os agentes econômicos, em decorrência admitiria a entrada de vários geradores. No obstante via legislativa é possível controlar a interconexão à rede de distribuição local, impondo limites de participação para as energias renováveis. Adicionalmente, a regulação para geração de energia também tem como critério de competição o cenário do mercado competitivo de compra e venda de energia elétrica nos leilões, desde a perspectiva regulatória também se contemplam as figuras jurídicas de produtor independente e o regime de autoprodução de energia aplicável à fonte eólica.

O vento em termos gerais é de livre utilização, porém, quando visto como recurso energético adquire uma dimensão jurídica e econômica relevante e ponderável, já que pode receber uma valoração onerosa de uso ou troca, que permeia as relações com caráter jurídico. $\mathrm{O}$ vento em si mesmo considerado como bem ambiental não se articula nem com as categorias jurídicas de bem público, nem de bem privado, o que em consequência o desvincula das figuras jurídicas da propriedade privada e da posse (CURSO. . , 2018). Embora, no caso das usinas eólicas ou parques de geração eólicos, pode-se afirmar que têm uma afetação à prestação do serviço público de energia, mesmo quando a propriedade do terreno e da tecnologia de geração é regida pelas normas do direito privado.

A energia eólica deve ser vista com o potencial de se desenvolver no regime de serviço público atrelado à cadeia produtiva de energia elétrica, principalmente quando 
se adota uma visão contemporânea da categoria jurídica de serviço público. Pois, em muitas das etapas do processo de implementação dos parques eólicos se admite a concorrência de modo a existir total liberdade para que os empreendedores selecionem a tecnologia com a qual possam aperfeiçoar o aproveitamento do potencial eólico.

Se acolhermos o caráter funcional dos bens públicos com os quais se gera energia elétrica, a partir da fonte eólica, poderiam ser catalogadas como bens públicos por sua afetação à prestação de um serviço público, sendo passiveis de certas prerrogativas associadas a elas (MARQUES, 2009). Por esse viés é possível inferir a necessidade de se configurar o direito para benefício de uma servidão administrativa e para o aperfeiçoamento do uso de bens da geração eólica, o que se resulta bastante complexo, haja vista os bens poderem pertencer a particulares e receberem o tratamento de bens públicos pelo seu vínculo com a prestação do serviço público de energia.

A visão que aqui se expõe sobre a energia eólica como recurso energético renovável vincula-se com perspectiva do direito ambiental contemporâneo na qual os bens ambientais consideram-se direitos metaindividuais. A natureza jurídica destes direitos os localiza por cima dos direitos individuais, pelo tanto correspondem a danos jurídicos que se ocasionem a uma coletividade e são garantidos processualmente mediante ações populares ${ }^{9}$. Os direitos ambientais entendidos como metaindividuais, difusos e coletivos têm como característica sua titularidade indeterminada e interligada por condições de fato ${ }^{10}$.

As propriedades da tecnologia com a qual se gera energia elétrica a partir de fontes eólicas, em conjunto com os investimentos relacionados como o terreno e em geral os bens vinculados ao desenvolvimento do projeto, permitem que a propriedade seja privada. Nesse sentido, dentro dos requisitos que estabelece a normatividade brasileira para os projetos eólicos se requer a comprovação da propriedade ou posse direta do terreno necessário para a instalação da central geradora. Tal requisito é fundamental para poder requerer o cadastro para obtenção da Habilitação Técnica

\footnotetext{
${ }^{9}$ No Brasil a Lei 4.717 de 1965 foi a primeira em consagrar as ações populares.

${ }^{10}$ Decorrente da natureza jurídica dos direitos difusos, entre os que se encontram os direitos ambientais, é sua condição de ser indivisíveis, o que em palavras de CELSO ANTONIO FORILLO significa que "trata-se de um objeto que, ao mesmo tempo, a todos pertence, mas ninguém em específico o possui. É uma espécie de comunhão, tipificada pelo fato de que a satisfação de um só implica, por força, a satisfação de todos, assim como a lesão de um só constitui, ipso facto, lesão da inteira coletividade".
} 
dos respectivos empreendimentos à Empresa de Pesquisa Energética (EPE) segundo o previsto no Inciso II do parágrafo $3^{\circ}$ do Artigo $4^{\circ}$, da Portaria do Ministério de Minas e Energia (MME) n ${ }^{\circ}$ 102, de 22 de março de 2016.

Assim, para a entrada em operação da usina ou parque eólico se requer o cumprimento de uma série de requisitos de ordem técnica e regulatória, para adquirir uma autorização administrativa emitida pelas agências reguladoras. Não obstante, devese considerar que a outorga da autorização se encontra atrelada ao direito ambiental administrativo e está condicionada pelas exigências das autoridades nacionais com a finalidade da expedição de licenças ambientais, o que em última instância depende de estudos de impacto ambiental que precisam ser prévios à execução do projeto.

Ainda que o uso do recurso do vento não seja excludente, quando se afeta uma área para a construção de uma usina ou um parque eólico este adquire tal relevância jurídica que passa a ser considerado um bem público cuja utilidade se encontra limitada ao desenvolvimento e geração de energia eólica. Leva-se em consideração que a área é um bem público que se submete ao regime jurídico do direito público e sua gestão se submete à constante fiscalização pelos diferentes órgãos do Estado.

É importante frisar que se bem a fonte eólica pode ser catalogada como energia limpa de baixo impacto ambiental, isso não exclui a possibilidade de que também apresente algumas externalidades negativas, como o comprometimento da paisagem (ZERRAHN, 2017). O patrimônio nacional engloba toda a riqueza intangível com relevância para a nação sem que isso signifique travar uma relação econômica individualizada. Dentro do patrimônio dos Estados também se encontra o patrimônio paisagístico, o qual merece especial proteção, visto que não se tem qualquer referência jurisprudencial sobre o tema do comprometimento paisagístico pela proliferação de empreendimentos eólicos atualmente. Contudo, é possível que no futuro existam controvérsias nesse sentido, como acontece na Europa.

$\mathrm{Na}$ análise ambiental deve ser estimado que de um lado se tenha a necessidade do governo de consolidar uma economia para evitar o efeito estufa com a redução de dióxido de carbono, e de outro se tem que a energia eólica é absolutamente compatível, mas pode gerar prejuízo paisagístico nas áreas com elevado potencial eólico onde se desenvolvem os projetos. Em termos gerais pode-se dizer que a energia eólica se 
harmoniza com as políticas nacionais sobre mudanças climáticas, no caso brasileiro a Política Nacional sobre Mudança do Clima é contemplada na Lei 12.187 de 2009.

\subsubsection{A Exploração da Energia Eólica e a Concorrência}

Segundo o critério "competição onde possível e regulação quando necessário", e em razão da desagregação da cadeia de produção do serviço público de energia elétrica em geração, transmissão, distribuição e comercialização, a geração e a comercialização de energia elétrica encontram bastante liberdade. Contudo, no caso específico da geração distribuída eólica, não há monopólio natural que exclua os agentes econômicos. Gerar energia eólica é uma atividade econômica altamente competitiva, que depende de certas condições climáticas facilmente previsíveis com a tecnologia atual.

Pode-se inferir que a energia eólica se encontra dentro das atividades econômicas que admitem a livre iniciativa, além de ser uma atividade que está aberta às inovações tecnológicas para sua exploração. A instalação de centrais geradoras eólicas constitui uma excelente alternativa em termos econômicos e técnicos (AUTHOR, 2014b), de modo a considerar que o desenvolvimento tecnológico contribui para a otimização no aproveitamento do vento e na melhora da capacidade instalada.

Quando se revisa o conceito de serviço público com uma visão restritíssima, a fim de atender a classificação de Alexandre Santos de Aragão, o concebemos como atividades econômicas remuneradas por taxa ou tarifa que podem ser inseridas entre as que devem ser exploradas e/ou garantidas pelo Estado, conforme se vislumbra no artigo 175 da Constituição Federal. Neste trabalho o conceito de serviço público abordado se atrela a exploração de uma atividade econômica que pode ser desenvolvida tanto pelo setor privado quanto pelo setor público, mas em qualquer dos casos é aplicável o regime jurídico próprio dos serviços públicos (ARAGÃO, 2005).

Gerar energia eólica é uma atividade econômica competitiva, que depende de condições climáticas facilmente identificáveis com a tecnologia atual, sendo que a natureza da concorrência tem evoluído no setor elétrico. Tal competição é percebida no segmento da geração em particular, com uma concorrência pelo mercado para uma concorrência no mercado. Na primeira, por acepção, encontra-se a possibilidade de 
que os geradores participem de uma parcela do mercado, garantindo-se o ingresso; já na segunda é a possibilidade dos agentes competirem entre si no mercado que estabelece os preços competitivos, tal como nos leilões de energia.

Não há grandes barreiras de entrada no mercado de energia eólica, além dos investimentos e estudos requeridos, diferente do que ocorre em outros segmentos da cadeia de produção elétrica, nas quais existe um monopólio natural na transmissão, distribuição e geração de energia, como no caso das hidrelétricas. Para este último tipo de geração o ingresso no segmento econômico, esta condicionado à satisfação de requisitos maiores e a uma etapa prévia de competição, como o processo licitatório.

Neste ponto nos distanciamos da doutrina tradicional do serviço público, segundo a qual estes serviços guardam uma relação direita com os bens públicos e representam um privilégio para seu exercício, de maneira a os tornar excludentes. Por esse viés seria difícil entender que a energia eólica só tem concorrência no mercado, tal como se vem apontando ao longo da presente discussão, o que permite afirmar o impacto do direito de concorrência, para o mercado especifico de geração de energia eólica não pela disputa de entrada neste mercado, senão pelo ganho de permanência nele.

Em muitos casos o preço da energia não mantém uma correlação com seu custo verdadeiro de produção (AUTHOR, 2014b). o que depende dos suportes institucionais de cada fonte de geração. As fontes convencionais costumam ter arranjos regulatórios e incentivos, como subsídios, muito embora o leque das renováveis vem abrindo espaço para maior competitividade. No cenário de concorrência na geração de energia eólica se disputa pela presença no mercado por meio de preços competitivos. Com os constantes aportes tecnológicos pode ser auferida uma importante redução de custos das turbinas eólicas, da operação e manutenção, o que favorece o custo final do investimento e leva a uma queda imediata no custo unitário de energia eólica por kWh.

\subsubsection{Instrumentos jurídicos para a exploração da energia eólica}

Um dos instrumentos jurídicos que já encontramos são os leilões, que foram objetos de revisão anterior no decorrer deste trabalho. A energia eólica é vendida em leilões em que a ANEEL emite uma autorização para a entrada em operação do par- 
que eólico após verificar as questões técnicas para a viabilidade e configuração com a rede de transmissão. Quando se está no marco de energia eólica para efeitos regulatórios vão ser comprometidas as atividades de geração e transmissão como impulsoras desta fonte renovável.

Dentre os instrumentos jurídicos com que conta a fonte de energia eólica para ganhar abrangência, encontram-se as parcerias público privadas (PPP), empreendimentos de infraestrutura nos quais convergem interesses e necessidades do setor público e privado. Munido dessa ferramenta jurídica o investidor privado é remunerado diretamente pelo governo ou mediante a cobrança de tarifas e recursos provenientes do setor público, segundo estipulado pela Lei 11.079 de 2004 de PPP.

Para determinar o regime jurídico aplicável na geração de energia, as usinas são classificadas conforme a fonte e sua capacidade de geração, como se verá mais adiante. A autorização na doutrina do direito público se classifica como um ato administrativo de espécie e nesta subclassificação a geração de energia eólica poderia ser rotulada como uma autorização de serviço público. Este ato administrativo que contem a decisão da administração pública se configura como unilateral precário e discricionário.

Entretanto, a autorização para gerar precede outra, que deve tramitar o empreendedor, ou seja, a autorização para a medição dos ventos deve ser pelo período mínimo de um ano, sendo que tal procedimento inclui a instalação de torres anemométricas. Afastando-nos um pouco do que sinaliza a doutrina, em matéria das autorizações que requer a energia eólica há um restrito espaço para a discricionariedade, pois uma vez que o gerador se sujeite à normatividade para sua entrada em operação, decorre necessariamente sua aprovação. Outro ponto que se afasta da doutrina é a condição de precariedade do título, advinda do prazo de vigência que, segundo o professor Floriano de Azevedo Marques Neto, obedece a uma autorização qualificada.

A autorização requerida para os empreendimentos eólicos de grande porte tem uma série de obrigações contratuais que Ihes fazem se submeter a continua fiscalização pela ANEEL por meio da Superintendência de Fiscalização dos Serviços de Geração. Devido à expansão e a segurança do sistema, a fiscalização é de interesse geral para a satisfação das obrigações contratuais que decorrem dos leilões. 
A construção de usinas e parques eólicos e sua entrada em operação requerem habilitação emitida pela autoridade competente, que no caso de energia elétrica é a ANEEL. Para determinar a necessidade de registro ou autorização deve ser observado o que contempla a normatividade específica da eletricidade sobre os limites de geração: os projetos com capacidade instalada até cinco $\mathrm{MW}$, que tenham a conotação de autoprodutores, produtores independentes, correspondem a um primeiro tipo; um segundo tipo se refere a geração destinada ao serviço público de energia. No segundo caso a autorização dos geradores tem de passar do limite de cinco MW, de forma a contemplar as resoluções da ANEEL No. 393, 394 e 396 de 1998.

No caso do autoprodutor ou produtor independente de energia eólica aplica-se o previsto no Decreto No. 2.003 de 1996. E para este tipo de geração que se cataloga como energia distribuída ${ }^{11}$, a normatividade também estipula o livre acesso às redes de transmissão e distribuição de energia como garantia para ter o respaldo do Sistema Interligado Nacional (SIN) no caso de seu sistema apresentar alguma falha ou no caso de se desejar exportar a sobra de sua produção e efetuar operações de comercialização.

Para sua entrada em operação o gerador requer uma autorização e registro emitidos pela ANEEL, segundo os termos das resoluções No. 390 e 391 de 2009. Nos leilões de energia hidrelétrica existe a necessidade de incluir o processo licitatório, para a energia eólica isso não se faz necessário já que apenas se requer autorização administrativa.

\footnotetext{
${ }^{11} \mathrm{~A}$ energia distribuída consiste em gerar energia perto do local de consumo e a legislação brasileira oferece a opção ao consumidor de gerar sua própria energia, o que se disciplina mediante a Resolução Normativa ANEEL $n^{\circ} 482 / 2012$, sumamente importante para que o consumidor tenha livre acesso as redes de distribuição a fim de não correr o risco de interrupção do serviço. Para tal, o consumidor deve contar com um contrato de conexão com uma distribuidora.
} 


\section{REGULAÇÃO E PLANEJAMENTO ENERGÉTICO PARA A TRANSIÇÃO ENERGÉTICA}

A energia elétrica ocupa importante espaço na agenda política, econômica e social dos países, conduz ao desenvolvimento e sua adequada regulação decorre em grande parte do avanço ou retrocesso da economia nacional. Neste capítulo são abordados os aspectos institucionais trabalhados na atividade de planejamento do setor elétrico, como ação estratégica do Estado e sua influência para a transição para as energias renováveis. As ações de planejamento posteriormente se materializam em políticas públicas que incentivam o avanço em matéria de transição energética. Igualmente, o planejamento impacta à energia eólica como uma das principais fontes renováveis no cenário brasileiro, o que específica seus contornos normativos, técnicos, econômicos e ambientais.

Os planos nacionais de energia desenvolvidos em todos os países representam a perspectiva do setor elétrico, o que contempla as ações, diretrizes, políticas públicas e as estratégias para alcançar os objetivos de desenvolvimento. As metas do setor elétrico se encontram relacionadas com os princípios da prestação de serviços públicos, tais como a continuidade, universalização do serviço, segurança do sistema elétrico e tarifas acessíveis, sendo as energias renováveis fundamentais para seu cumprimento.

Para que posa efetuar-se a transição do setor elétrico rumo à energia renovável, existem dificuldades tanto jurídicas quanto técnicas. Entre as jurídicas encontram-se: (i) a incoerência normativa com os objetivos do setor elétrico, os planos de expansão plurianuais e decenais, e o ordenamento jurídico vigente, (ii) a avaliação da conveniência de uma modificação na legislação atual ou nova legislação, (iii) a necessidade de novos modelos contratuais, para interatuar com os comercializadores, distribuidores e transmissores; (iii) a revisão dos modelos contratuais para que os usuários do serviço público de energia elétrica, possam converter-se em autogeradores e inclusive exportar seus excedentes de energia à rede de distribuição local, o que implicaria uma alteração ao tradicional contrato de prestação do serviço público de energia elétrica; (iv) o cumprimento da garantia do principio de livre acesso às redes de distribuição e transmissão para os novos geradores de energia, sob a figura de autogerador, coge- 
rador ou gerador que pretende participar no mercado do comercialização de energia; e (v) a reestruturação do modelo institucional para atribui-Ihe mais segurança jurídica ao setor elétrico.

Enquanto às dificuldades técnicas, se encontram: (i) a dificuldade de armazenar a energia, (ii) os altos custos das baterias que não logram ser amortizados durante a vida útil dos projetos financeiros das baterias, (iii) as energias renováveis não se podem submeter ao despacho centralizado dos sistemas interconectados nacionais devido à instabilidade na geração de energia, e (iv) o traspasso de corrente continua a corrente alterna, que requere desenvolvimento tecnológico para sua harmonização (PAINULY, 2001) (FERREIRA, 2007).

A atividade de planejamento para o setor elétrico considera uma margem de eficiência esperada do sistema elétrico, a mediano e longo prazo, o que a instituição encarregada deve estruturar de forma ótima segundo as projeções de demanda e oferta de energia. Para isso, se parte da premissa de que o sistema requer segurança para operar e, para tanto, a oferta terá de ser superior à demanda de forma que se evitem os colapsos elétricos ou blackouts como os que têm ocorrido em diversas latitudes, justamente por problemas de planejamento e gestão do setor elétrico, vinculados a situações em que não foram realizados os investimentos demandados em infraestrutura ou diversificado a oferta de energia para expandir a prestação do serviço público de modo a cobrir a demanda eficientemente.

O peculiar do setor elétrico é que, independentemente do modelo regulatório que se adote é infactível deixar o tema do planejamento livre às forças do mercado, pois o que está em jogo é a prestação de um serviço público fundamental para o desenvolvimento e o bem-estar dos países. Em consequência disso, o planejamento, embora seja um indicativo em sentido tradicional no que remete ao setor elétrico, deve ser eficientemente gerenciado de modo que se execute o previsto ao interesse público imerso no setor elétrico.Neste último sentido, o planejamento do setor elétrico é, sem dúvida, uma técnica de intervenção do Estado na economia: "pretende conduzir, racionalizar ou submeter a um delinear prévio a atividade econômica, em função daquilo que se considera necessário ou vantajoso para a conjuntura do país" (ARIÑO, 2004) (Tradução própria). 
No que compete ao aspeto da oferta de energia, os desafios estão determinados pela expansão constante, de tal maneira que se atenda a demanda, o que requer grandes investimentos, geralmente provenientes do capital privado e estrangeiro. Isso em cumprimento do recomendado para a América latina no conhecido consenso de Washington, no qual se estipularam as pautas para a abertura de investimentos estrangeiros diretos, para as privatizações de empresas públicas, para a desregulação dos mercados, dentre outros (WILLIAMSON, 1996). Este paradigma neoliberal compactado no consenso de Washington teve suas críticas, segundo o empresado pelo professor Fernández Rozas "descarta em essência aspetos como os da equidade, o crescimento, o problema ecológico, a melhora dos níveis de qualidade de vida e o desenvolvimento democrático" (FERNANDEZ, 2010)(Tradução própria)

Infere-se que o setor elétrico tem adotado muitas das consignas da ideologia neoliberal e não se pode descartar que tem sido de grande importância a atividade de planejamento. Esta não funciona como um instrumento de controle indicativo do setor, mas como instrumento obrigatório e coercitivo de controle do Estado perante prestadores privados.

Mesmo com o fenômeno das privatizações e desverticalizações empresariais do setor elétrico, o Estado não tem sido despojado de suas atribuições de controle e seguimento, as quais tem início com o planejamento e continuam até a atividade regulatória estar presente com o intuito de controlar especificamente a segurança do sistema, a qualidade na prestação do serviço, a continuidade e tarifas, e o comprometimento com objetivos ambientais para mitigar as externalidades negativas do setor elétrico.

Atualmente há o trabalho conjunto de diversos atores da sociedade relacionados a mitigação das mudanças climáticas, e o setor elétrico, por sua preponderância como elemento de crescimento econômico, não é alheio a essa demanda, pelo qual teve que incorporar objetivos ambientais. A questão ambiental vinculada ao setor elétrico encontra-se presente em aspecto como a eficiência energética, energias renováveis, redes inteligentes e por essa razão tem suportado os avanços tecnológicos (TOMAS, 2007). Em decorrência disso, as preocupações pelas problemáticas ambientais se erigem como um fator determinante dentro da política energética, ao ponto de levar a uma verdadeira transição energética à descarbonização. 
Além dos aspectos próprios do mercado, deve ser considerado o momento de realizar a atividade de planejamento, que na atualidade permite ao consumidor um papel proativo, fruto de um sistema democrático da gestão dos recursos públicos, que o leva a participar da configuração de diversas instâncias nas decisões políticas relevantes. Esse processo democrático se manifesta, por exemplo, na fase de planejamento em que tem sido implementadas as consultas públicas. Por meio de tais consultas os órgãos encarregados das decisões recebem as contribuições da sociedade, o que inclui desde empresas do setor elétrico, a consumidores e organizações não governamentais.

Já na fase de gestão do setor elétrico, as manifestações de democracia se evidenciam com a possibilidade de figuras como a autogeração e cogeração de energia, ou com a possibilidade de associações de usuários. Todas estas modalidades permitem a sociedade civil e aos usuários participar ativamente na prestação do serviço e da cobertura de suas necessidades, tendo como premissa a garantia e a efetividade do princípio de livre acesso às redes de distribuição local. Nas palavras de David Held, esta modalidade democrática constitui uma das esferas do poder específicas, na qual "os indivíduos ou grupos de indivíduos podem promover seus próprios projetos, independentemente da intervenção direta do Estado" (HERLD, 1997).

Quando para a ação e a decisão política do Estado se adotam políticas públicas a fim de materializar a transição energética, os efeitos buscados abarcam desde a criação de um espaço no mercado para as energias renováveis no âmbito nacional até o local.Isso permite que a transição energética impacte todas as esferas da sociedade, de modo que o processo seja mais eficiente e efetivo na medida em que diversos níveis de planejamento, gestão e regulação assumem uma posição política e econômica segundo suas particularidades. Conservada a visão comum sobre a necessidade iminente de diversificar a matriz energética e dotar o sistema de segurança e confiabilidade, diminui-se a vulnerabilidade a crises energéticas.

Dentro da transição energética, apostar em energias alternativas é uma questão de planejamento estratégico para o setor elétrico, já que quando ingressam no mercado é indispensável favorecê-las com estímulos fiscais e regulatórios. De fato, inicialmente podem não ser viáveis economicamente, mas quando se vislumbram suas vantagens em longo prazo suas contribuições sociais, econômicas e ambientais são 
patentes, como constata no decorrer desta pesquisa.

\subsection{Planejamento energético no Brasil e energias renováveis}

No Brasil a atividade de planejamento do setor elétrico está nas mãos da dde Pesquisa Energética, cuja criação foi autorizada no ano de 2004, mediante a lei 10.847. Por meio desta lei reestruturou-se o setor elétrico brasileiro, que passou da verticalização à desverticalização das atividades de geração, transmissão, distribuição e comercialização de energia. Posteriormente, ele se abriu ao processo de privatização, tornando necessário o surgimento de instituições do setor público que deram conta das atividades de planejamento e regulação do setor. Mediante o Decreto No. 5.184, de 16 de Agosto de 2004 foi criada EPE, como empresa pública, com personalidade jurídica e como pessoa jurídica de direito privado, vinculada ao Ministério de Minas e Energia.

No artigo $2^{\circ}$ se estabeleceu como finalidade da EPE prestar serviços na área de estudos e pesquisas destinadas ao planejamento do setor elétrico:

Art. 20 A EPE tem por finalidade prestar serviços na área de estudos e pesquisas destinadas a subsidiar o planejamento do setor energético, tais como energia elétrica, petróleo, gás natural e seus derivados, carvão mineral, fontes energéticas renováveis e eficiência energética, dentre outras.

Desde a criação da EPE se tem projetado planos e programas específicos para o setor elétrico, além do plano nacional de energia que conta com planos e programas de ação específicos para a demanda e para a oferta de energia elétrica. A atividade de planejamento do setor elétrico é plasmada nos planos decenais de energia, nos planos nacionais de energia e nos balanços energéticos, dos quais se estima a projeção da capacidade instalada requerida para atender a demanda elétrica.

O planejamento do setor elétrico no Brasil tem o componente de vinculante, justamente a partir da crise de abastecimento energético de 2001 (RODRIGUES, 2011). O enorme risco de repetir o Tribunal de Contas da União corrobora a implementação anual dos Planos Decenais de Energia a fim de constatar o estado dos projetos e avaliar o nível de cumprimento. A decisão de acompanhar o setor elétrico foi tomada pela 
Decisão No. 456 de 2002 TCU, resultante do processo No. 005.308/2001-6.

A energia que tem preponderância na matriz elétrica brasileira é a hidrelétrica, que pode ser considerada uma energia limpa, porém esta dotada de um componente de incerteza alto por sua vinculação as condições climáticas, o que a torna vulnerável, principalmente em tempo de seca. Esta característica leva a necessidade de recorrer a outras fontes de energia e diversificar a matriz energética com a finalidade de um sistema mais confiável e para afrontar esta condição é preciso contar com um sistema normativo de instituições sólidas ante as crises.

O Brasil é um país rico em recursos naturais, o que torna viável a diversificação e realocação de recursos energéticos, de tal forma que sejam complementares entre eles e com a fonte de energia predominante no caso brasileiro, a hidrelétrica. A energia eólica conta com tal característica de complementaridade devido a questões de sazonalidade que permitem sua harmonização, já quem tempos de seca o vento permanece constante e forte. Ainda que a energia eólica não seria a única alternativa possível no objetivo de diversificar as fontes, possui condições particularmente favoráveis.

Tal como se encontra registrado no Plano de Expansão de Energia 2020 e no Plano Nacional de Energia 2030, de maneira que se mantém a previsão de aumento das fontes renováveis graças a contribuição de políticas públicas que incentivam o crescimento do mercado destas fontes, assim preservando o interesse do governo e do setor elétrico em manter um desenvolvimento sustentável na geração de energia elétrica. Segundo a Empresa de Pesquisa Energética, o Brasil é um dos países que menos emite gases ao gerar energia elétrica, fato que tende a melhorar com a entrada em operação dos parques eólicos e das usinas de biomassa (PLANO. . , 2014)

Nos planos decenais de energia, elaborados desde 2003, começa-se a trabalhar na incorporação das energias renováveis, pois se a função do planejamento é efetuada em consideração a problemática ambiental, as possibilidades de se ter um setor elétrico sustentável se elevam consideravelmente (GELLER, 2002). De fato, ao incorporar energias renováveis o Estado ajuda a si próprio na gestação de energia e, ao mesmo tempo, obtém benefícios perante a comunidade internacional, Conforme veremos no terceiro capítulo. 


\subsubsection{Planejamento energético aplicado à energia eólica}

O planejamento energético é uma questão que deve ser abordada de modo a considerar a energia como serviço público que impacta diversas frentes sociais, desde a qualidade de vida dos habitantes até o desenvolvimento econômico do Estado. A expansão da oferta de energia elétrica requer um planejamento articulado e sistemático que considere as variáveis dos preços do mercado energético, os recursos, a regulação, as tecnologias e o meio ambiente. No que tange a energia eólica, (juntamente com a biomassa e as $\mathrm{PCH}$ ), encontra-se como principal impulsor o Programa de Incentivo às Fontes Alternativas (PROINFA). Neste programa se integraram os diversos interesses da sociedade, do Estado e do mercado para incrementar a participação da energia limpa e se afastar da dependência da energia hidrelétrica ou inclusive do comprometimento da sua soberania energética. Desde a técnica legislativa e regulatória que recai sobre o setor elétrico, o Estado exercerá estratégias cada vez mais sofisticadas na alocação de recursos energéticos.

A função do planejamento estratégico do governo previsto para as fontes alternativas de energia guarda concordância com o critério de planejamento para o desenvolvimento previsto na Constituição Federal em seu artigo 174.

Art. 174. Como agente, na forma da lei, as funções de fiscalização, incentivo e planejamento, sendo este determinante para o setor público e indicativo para o setor privado. $\S 1^{\circ}$ A lei estabelecerá as diretrizes e bases do planejamento do desenvolvimento nacional equilibrado, o qual incorporará e compatibilizará os planos nacionais e regionais de desenvolvimento.

É necessário considerar que a eficácia dessa tarefa do Estado repercute na qualidade da prestação do serviço público de energia elétrica e na segurança do sistema elétrico brasileiro, mas não é uma tarefa na qual o Estado encontra-se isolado, já que aborda diversos atores, instituições e ideias. Quando se elaboram políticas públicas em matéria energética é indispensável o conhecimento sobre as diversas fontes de energia, seu potencial e sua localização geográfica para prever sua conexão ao SIN. A informação referida permite estruturar políticas públicas que viabilizem sua implementação efetiva seguindo as prioridades do Estado. 
A necessidade de diversificação das fontes de energia elétrica é um fato praticamente institucionalizado nos níveis nacional e internacional, que precisa de arranjos normativos e regulatórios para que as decisões sobre incentivos para a diversificação gerem as mudanças projetadas, alocando os recursos de forma eficiente. Efetuar o planejamento do setor elétrico vislumbrando um aumento das fontes renováveis de energia é uma questão estratégica para o desenvolvimento do Brasil, o que tem efeitos domésticos e internacionais. Domesticamente as externalidades positivas esperadas do planejamento vislumbram a cobertura do serviço a regiões não interconectadas ao SIN, segurança do sistema elétrico, soberania energética, contribuição com a redução de emissões de CO2 e contribuía ao aumento de empregos,

O PROINFA tem sido uma ferramenta importante para o caminho da diversificação. Em torno dele continuamente o governo, representado pelo Ministério de Minas e Energia, redefiniu metas para a ampliação da capacidade instalada e a operação comercial das energias renováveis. Este programa desde a perspectiva de efetividade do desenho de políticas públicas compatibiliza as metas do setor elétrico de diversificar as fontes com os meios políticos e econômicos para alcança-las (HOWLETT; RAMESH; PERL, 2013). A seleção dos instrumentos técnicos como uma das dimensões relevantes no processo de definição de políticas pública, quando aplicado ao às energias renováveis o constitui o fato de selecionar dentre as energias renováveis quais devem ser incentivadas e quais não. Este tipo de decisões têm suporte em dados técnicos, como a disponibilidade dos recursos e sua localização geográfica e a atratividade para atrair investidores.

No processo de modulação de políticas públicas é importante estar dotado de dados e critérios técnicos com a finalidade de permitir que os atores com competência para tomar decisões tenham maior objetividade no processo de privilegiar uma determinada fonte de energia e incentivar sua inserção ou crescimento na matriz elétrica. Para isso eles devem ter uma visão holística dos recursos e estudar cada uma das fontes elétricas em seus aspectos técnicos, sociais e econômicos, além de seus impactos ambientais. Esse processo deve ser o mais transparente possível para que sejam criados indicadores com os quais se fundamentem as escolhas, vislumbrando uma gestão mais eficiente.

Desde a perspectiva teórica das políticas públicas se faz ênfase em que as de- 
cisões plasmadas nelas têm como agente primário o governo; essas decisões são abordadas de forma consciente e deliberada pelos órgãos públicos que conhecem em detalhe as necessidades do seu setor. Por conta da institucionalidade que permeia a decisão em matéria de políticas públicas para energias renováveis, vincula-se também com o planejamento dos recursos energéticos que acontece de forma macro institucional e constitui um trabalho conjunto do Ministério de Minas e Energia (MME) e a EPE, o Conselho Nacional de Política Energética (CNPE) e a Secretaria de Planejamento e Desenvolvimento Energético, (SPE). Estas instituições contam com certa maturidade, haja vista terem sido criadas no final dos anos noventa e possuírem atuação consistente e coordenada junto às diretrizes de política energética. Tudo contribui na busca para maior eficiência e eficácia nos estudos de planejamento, para que o setor elétrico se mantenha adequado e dotado de confiabilidade e segurança em seu sistema.

Perante as crises energéticas é questionável a eficiência da função de planejamento do Estado e da administração pública, levando em consideração que se trata de um setor estruturante da economia e que conta com vários órgãos que suportam as decisões do governo em matéria de planejamento, os quais foram nomeados anteriormente. Assim, deve-se propender pela sua harmonização nas decisões que afetam a confiabilidade.

Com a informação concreta sobre as variáveis que afetam cada fonte de energia elétrica, a escolha para o governo e para os futuros investidores se torna mais racional, circunscrevendo a decisão aos dados previamente selecionados como relevantes. $\mathrm{Na}$ conformação desta informação, deve existir um conhecimento multidisciplinar para abranger diversos cenários que conduzam à eficiência no planejamento e na gestão dos recursos energéticos.

Na literatura (SOARES; OLIVEIRA, 2006) enunciam uma série de indicadores de caráter técnico, social, econômico e ambiental que podem ser projetados, tanto para a etapa de construção, como a de operação de geração de energia elétrica (tabela 1). Por sua vez, tais indicadores podem facilitar a etapa de avaliação das energias renováveis de modo a determinar seu potencial de contribuição à matriz energética $e$ suas externalidades positivas e negativas. TABLA 1

Quando avaliados os indicadores é possível ter um panorama abrangente do que 
Tabela 1 - Indicadores utilizados para a geração de energia elétrica.

\begin{tabular}{|c|c|}
\hline \multicolumn{2}{|c|}{ INDICADORES AMBIENTALES } \\
\hline Consumo de água & $\mathrm{m}^{3} / \mathrm{MWh}$ \\
\hline Emissão de gases efeito estufa & ton-eq $\mathrm{CO}_{2} / \mathrm{MWh}$ \\
\hline Área ocupada pelo empreendimento & $\mathrm{m}^{2} / \mathrm{KW}$ \\
\hline $\begin{array}{l}\text { Emissão de gases acidificantes da atmosfera } \\
\text { (NOx) }\end{array}$ & $\mathrm{kg} / \mathrm{MWh}$ \\
\hline Percentual de utilização do solo & $\%$ \\
\hline \multicolumn{2}{|l|}{ INDICADORES SOCIAIS } \\
\hline Número de Empregos & empregos/MWh \\
\hline $\begin{array}{l}\text { Nível médio de renda do empregado no empre- } \\
\text { endimento }\end{array}$ & $\mathrm{R} \$ /$ empregado \\
\hline Qualificação do Emprego & qualitativo \\
\hline \multicolumn{2}{|l|}{ Variação da renda local } \\
\hline \multicolumn{2}{|c|}{ INDICADORES ECONÔMICOS } \\
\hline Investimento total & US $\$ / k W$ \\
\hline Índice custo beneficio & $\mathrm{R} \$ / \mathrm{MWh}$ \\
\hline Percentual de insumos importados & $\%$ \\
\hline \multicolumn{2}{|c|}{ INDICADORES TECNOLOGICOS } \\
\hline Eficiência liquida de geração & $\%$ \\
\hline Disponibilidade média anual & $\%$ \\
\hline $\begin{array}{l}\text { Grau de complementaridade ao sistema elé- } \\
\text { trico Interligado }\end{array}$ & quantitativo \\
\hline Tempo de construção & meses \\
\hline \multicolumn{2}{|c|}{ POTENCIAL DE GERAÇÃO DISTRIBUIDA } \\
\hline Energia elétrica disponível & GW/ano \\
\hline
\end{tabular}


cada fonte de energia renovável pode oferecer para o mercado elétrico e para a sociedade em geral. No momento de criar uma política pública que priorize a determinada fonte de energia, o processo se torna mais transparente com esta delimitação de critérios de decisão, conforme expostos na tabela anterior o que torna menos complexas as etapas posteriores de avaliação e controle. Pode-se afirmar que existe no contexto institucional, uma tarefa ainda não realizada referente ao desenvolvimento das fontes alternativas de energia, para o qual é fundamentar projetar as energias renováveis dentro planejamento estratégico do setor elétrico e posteriormente plasmar-Iho em políticas públicas, que é onde se executam as estratégias. Não obstante, a relevância de aprofundar os critérios de decisão está dada em função da parcela que se projeta na matriz elétrica, por seu potencial de atender a demanda e os parâmetros de segurança e confiabilidade do sistema elétrico brasileiro.

\subsection{Revisão dos incentivos mais implementados no contexto internacional para a energia eólica}

Nos investimentos de novos negócios como são as novas tecnologias para geração de energia renovável o risco é muito elevado, além disso, elas não contam com um espaço garantido dentro do mercado energético que costuma ter preponderância de outras fontes de energia como a térmica, a nuclear ou a hidrelétrica. Justamente pelo alto custo inicial e pela incerteza do retorno, somado aos requerimentos do sistema elétrico de responder à demanda com segurança e continuidade na prestação do serviço é que são elaboradas as diferentes políticas públicas para incentivar os investimentos em energia renovável.

Para levar a bom termo aos planos e programas com os que se incentivam às energias renováveis o governo precisava de investimentos privados, para isso, teve que criar um cenário de segurança jurídica com procedimentos e contratos padronizados e critérios técnicos que garantiriam condições de qualidade para cada fonte de energia. A interação entre o Estado e a sociedade para contar com um panorama completo dos recursos e das necessidades para consolidar as políticas públicas ocorre em várias instâncias institucionais e cada vez mais resulta de processos mais participativos e democráticos. 
Entre a diversidade de instrumentos implementados destacasse principalmente 0 Feed-In Tarif (FiT) onde se garante a compra da energia e o preço estável, sendo um negócio jurídico que usufrutua bastante segurança jurídica, econômica e regulatória. Um segundo incentivo, é a tarifa Premium com um bônus adicional que inclui um fator competitivo e garante um preço máximo e mínimo para as tarifas de energia renovável. Outra possibilidade já para mercados mais estáveis são os incentivos com certificados verdes ou sistema de cotas onde é imposta a obrigação de ter uma porcentagem de energia comercializada a partir de energia renovável. Finalmente o sistema de leilões onde se garante a participação de diversos agentes e se consegue competitividade de preço.

\subsubsection{Feed-in Tariff para energia eólica}

O FIT constitui um instrumento muito eficiente para incentivar a entrada de novos agentes ao setor elétrico, já que esta se garantindo uma estabilidade no retorno dos investimentos para os que entrem no mercado das fontes renováveis de energia. Este incentivo tem uma repercussão no preço da energia, por meio de contratos de longo termo, com baixo risco e garantindo uma tarifa de remuneração estável. O sucesso do modelo de FIT acontece na medida em que o retorno esteja adequadamente estruturado dentro do contrato, de tal forma que consiga pagar os investimentos e deixe uma margem de lucro (COUTURE, ).

O instrumento regulatório e econômico mais implementado para incentivar a inserção de energias renováveis na matriz energética tem sido o FIT, com suas respectivas adaptações nas diferentes regulações. Emerge como um instrumento para romper as barreiras de entrada imposta para as energias renováveis dando estabilidade no investimento devido á facilidade de contar com uma tarifa fixa que permite projetar o retorno do investimento.

Particularmente no Brasil o FIT foi aplicado no marco do PROINFA garantindo contratos de 20 anos assinados entre os geradores e a empresa Eletrobrás, mas o processo teve a particularidade de ser competitivo, estabelecendo alguns critérios para aceder a este benefício como contar com licencia ambiental para ser habilitado na concorrência dos contratos. 
Com o regime regulatório FIT os geradores ainda não participam do mercado elétrico como tal, é dizer que não interagem com as outras fontes de geração nem participam do cotidiano do mercado e suas formações de preços. Isso de alguma maneira prejudica a capacidade dos geradores eólicos de perceber diretamente os sinais do mercado e os riscos implícitos que se derivam da sua participação (HUENTELER, ).

Este tipo de incentivo é estruturado para ser temporal, cada governo terá que avaliar os sinais que recebe do mercado, em termos de aumento da capacidade instalada e também avaliando o nível de cumprimento dos contratos. Então, paulatinamente serão retirados estes incentivos de FIT em função da maturidade do mercado de energia renovável e das necessidades energéticas específicas de cada país, mas certamente FIT constitui a base a partir da qual vão se criar as condições para que a energia renovável ganhe espaço no mercado elétrico e sejam abertas outras possibilidades de incentivos mais acordes com a noção de concorrência.

\subsubsection{Tarifa premium e bônus adicional}

$\mathrm{Na}$ Espanha existem as duas possibilidades de remuneração ás que se podem acolher os geradores eólicos, um deles é o FIT e o outro é a tarifa premium com um bônus adicional. $\mathrm{O}$ modelo Premium abrange tanto a energia on shore quanto a gerada off shore e é uma das opções com as que se incentivou a energia renovável na Espanha; esse modelo foi institucionalizado a traves do Real Decreto 661/2007 onde se adoto a remuneração com um preço adicional, em detalhe está integrado por um preço fixo mais uma prima, que é atualizada anualmente, e também pode ter uma revisão a cada quatro anos, sem aplicação retroativa. Para determinar quando é aplicável a prima se estabeleceram limites do superior ou inferior.

Além do mais, os geradores recebem o preço do mercado elétrico e acima deste valor Ihes é outorgado um Premium pela energia gerada, sendo que os limites de remuneração os fixa previamente o órgão regulador. Este incentivo resulta mais atrativo para os investidores pela garantia de retorno ser ainda maior do que com o modelo de FIT, o que o torna menos vulnerável às instabilidades do mercado e com isso também estão reduzidos os riscos do mercado.

Com este mecanismo de remuneração com um bônus além da tarifa do mercado, 
se da um forte respaldo às energias alternativas e igualmente se ganha confiança no modelo regulatório e na planificação do sistema elétrico, isso graças à certeza da remuneração e à possibilidade de atualização por meio de revisões que garantem a objetividade do processo. A complementação da tarifa com a garantia de um pago adicional depende de vários fatores entre os que se encontram o nível de tensão no qual vai se entregar a energia à rede, a contribuição com o meio ambiente, a poupança em energia convencional que possa ocasionar a eficiência energética e os custos de investimento.

Ao ser um regime econômico tão favorável para incentivar os investimentos, se estabeleceu um prazo de um ano para sua implementação, tempo prudencial para dar aos investimentos eólicos o impulso requerido para sua consolidação, sem causar prejuízo à modicidade tarifaria.

\subsubsection{Certificados Verdes}

Também denominado sistema de cotas, consiste na estipulação legal da obrigação de ter uma cota de geração limpa, e esta cota pode ser produzida pelo próprio agente ou comprada de quem produz a energia renovável. Determina-se também a quantidade de geração requerida para obter um certificado verde, estes documentos por sua vez são negociáveis entre os agentes que têm a obrigação de ter geração de energia renovável e os produtores.

No Brasil tinha-se projetado para a segunda fase do PROINFA a emissão de certificados verdes, sendo o produtor quem emite o certificado no qual se informa o tipo de fonte primaria a partir da qual se gerou a energia e a quantidade de energia comercializada. Neste contexto o órgão regulador, neste caso a Agencia Nacional de Energia Elétrica (ANEEL) é quem tem a competência para efetuar a fiscalização e controle do sistema de cotas. Quando se constitui a dever de comercializar energia com uma cota que provem de energia renovável o destinatário desta obrigação podem ser tanto os geradores quanto os distribuidores. $\mathrm{E}$ do resultado da gestão de comercializar energia limpa também pode decorrer uma receita adicional para os agentes do mercado.

Adverte-se que este incentivo não é considerado de grande impacto no sistema de remuneração para os produtores de energia renovável. E só deve ser implemen- 
tado quando o mercado para as energias renováveis seja mais estável, já que não contribui muito a seu crescimento, devido a que tem implícito um risco maior e em muitas ocasiones os preços dos certificados verdes não necessariamente se ajustam aos custos da geração. Sendo assim, este mecanismo está dimensionado para geração de grande porte e que compreenda um importante volume para participar da comercialização de energia elétrica entre os agentes do mercado (SALOMAO, ).

\subsection{Políticas públicas implementadas no Brasil para energia eólica}

\subsubsection{Proeolica}

A iniciativa previa ao PROINFA para incentivar a geração eólica foi desenhada na Câmara de gestão de crises de energia elétrica, por meio da resolução No. 24 , de 5 de julho de 2001. A proposta buscava ter uma nova capacidade instalada de $1.050 \mathrm{MW}$ e a integra ao Sistema Interligado Nacional SIN e estabeleceu como prazo dezembro de 2003 para alcançar esta meta. Os contratos seriam assinados entre os geradores e a Eletrobrás com uma vigência de 15 anos.

Igualmente no tema de custos se estabeleceu que a energia comprada pela ELETROBRÁS fosse repassada às concessionárias de distribuição do sistema interligado, levando em consideração a proporcionalidade dos seus mercados realizados no ano anterior.

Certamente, este programa permite exemplificar a carência de planejamento eficiente e coordenação para sua execução, já que nada do projetado foi executado. Evidencia isso entre outras coisas no fato de que a ANEEL tinha a competência funcional para regulamentar o funcionamento do programa mais isso nunca surtiu efeito. Isso permite interpretar que se bem existia a identificação da problemática para atingir via política pública à inserção da fonte eólica, essa iniciativa não conseguiu se alinhar com a política energética para ter efetividade e durabilidade, o que nos leva a inferir que na formulação da política pública encontra-se desprovida de planejamento. 


\subsubsection{PROINFA: Base institucional e jurídica}

A iniciativa do PROINFA teve origem no governo do Fernando Henrique Cardoso, e foi fruto de todas as transformações regulatórias de desverticalização da cadeia produtiva de energia e as privatizações que se desenvolveram no setor elétrico na década dos 90, mas seus efeitos só se veriam no governo Lula. Neste último governo foram materializados todos os esforços para levar adiante as condições requeridas para que a política pública que incentivasse as energias renováveis tivesse os efeitos esperados para o setor elétrico. Notem-se como os impactos das reformas normativas e regulatórias são indispensáveis para conseguir avançar no objetivo de ter uma matriz energética limpa e que independentemente das filiações políticas do governo, o setor elétrico tem suas metas estratégias imersas no planejamento de longo prazo.

De outra parte, pode-se referênciar que no governo da Dilma os contratos originados no PROINFA continuaram surtindo efeitos, consolidando sua segurança jurídica e permitiu continuar o processo de avanço e maturidade no mercado e na matriz energética para as energias renováveis. Nestes diferentes períodos de governo, as políticas públicas para as energias renováveis têm sido alvo de ajustes pertinentes e incrementais corrigindo-se as disfunções técnicas e normativas do processo de inclusão de fontes alternativas, que atualmente conta com uma importante representatividade no mercado, e com a expectativa de crescimento continuo.

O marco jurídico do PROINFA é a Lei n 10.438 de 2002, com ela surge o programa, mas se faz necessária uma revisão e reajuste que se encontram contidos na Lei $n^{\circ} 10.762$, de 11 de novembro de 2003 e na Lei $n^{\circ} 11.075$, de 30 de dezembro de 2004. Posteriormente foi regulamentado mediante o Decreto 5.025 de 2004 e pelas Portarias MME 45 de 30 de março de 2004 e 452 de 2005. É cabível observar que a consagração no ordenamento jurídico deste programa encontra-se atrelado à política energética nacional lei 9.478 de 1997 e pelo tanto a interpretação do programa deve ser feita de maneira sistemática a lúmen da política energética nacional e acorde ao planejamento setorial.

O PROINFA potencializa e concretiza os esforços para diversificar a matriz energética brasileira com fontes renováveis de energia. O foco do programa foi o aumento da capacidade instalada de energia mediante a implementação de fontes limpas como 
são as pequenas centrais hidrelétricas (PCH) 33\%, biomassa 33\% e eólica (UEE) $33 \%$; adicionalmente, isso acarreia uma externalidade positiva que é a redução das emissões de $\mathrm{CO} 2$. Nesta mesma linha, inscrevesse entre os objetivos do programa, a busca por evitar grandes impactos no aumento das tarifas pela inserção de fontes renováveis, isso baixo o entendimento de que entre os princípios norteadores do setor elétrico está a modicidade tarifária, só que quando se quer inserir fontes alternativas nas matrizes elétricas uma consequência quase natural costuma ser o incremento do preço da energia pelo alto custo da tecnologia de geração de energia.

O sucesso do programa para atrair investidores a participar com a tecnologia das energias renováveis foi o resultado da criação de estímulos adequados para atrair investimentos com um marco jurídico que oferece confiança. Certamente, o suporte institucional que teve esta política pública propendeu pela garantia da entrada ao mercado de energia renovável, tal como aconteceu na primeira fase do PROINFA com o estimulo de fixação de preços garantindo contratos estáveis de longo prazo. Em decorrência, com o sistema de fixação de preços e contratos de compra e venda de energia garantiram um ambiente de mercado para as renováveis e abriu-se espaço para a tecnologia e prestação de serviços nacionais.

Os contratos assinados entre a Eletrobrás e os produtores independentes denominados com uma vigência de 20 anos (PPAs Power Purchase Agreement) foram a versão brasileira da aplicação da política de FIT explicada anteriormente.

\subsubsection{Funcionamento do PROINFA}

O PROINFA inicialmente previa duas fases para seu desenvolvimento, na sua primeira fase mediante a portaria No. 45 de março de 2004 o Ministério de Minas e Energia autorizo a Eletrobrás para que realizasse a primeira chamada publica com 0 fim de contratar energias renováveis em maio de 2004. O objetivo desta etapa era a contratação do montante de $3.300 \mathrm{MW}$ de potência instalada distribuídos proporcionalmente entre energia eólica, biomassa e pequenas centrais hidrelétricas, é dizer, $1.100 \mathrm{MW}$ para cada fonte.

O número de projetos que se apresentaram para aprovação superou as expectativas de participação, pois na primeira chamada pública se contrataram 2.527 MW, 
(1.100 MW de energia eólica, 1.100 MW de PCHs e 327MW de UTE. Mas os empreendimentos contratados no entraram em operação comercial na data prevista que era desde $01^{\circ}$ de janeiro a 30 de dezembro de 2006. Pelo que foi necessário adiar os contratos de compra venda de energia com Eletrobrás.

Outro importante aspecto da negociação prevista na regulação é referente ao grau de nacionalização dos equipamentos e serviços para o que foi estabelecida a porcentagem de $90 \%$ vislumbrando estimular o emprego e incentivar ao desenvolvimento tecnológico nacional. Este quesito gerou alguns problemas no início por que quando o PROINFA teve início o país não estava preparado para fornecer a tecnologia suficiente que cobrisse a demanda do mercado, nem tinha a capacitação e treinamento para tanto, o que contribuiu com que a entrada em operação comercial dos empreendimentos fosse atrasada.

Em 2005 o fornecimento de equipamentos para o mercado de energias renováveis só contava com dois provedores para a tecnologia de turbinas eólicas com capacidade de produção de $500 \mathrm{MW}$ por ano, cifra que estava longe dos requerimentos do mercado (ABEEOLICA, 2011).Neste aspecto se tem evoluído bastante já que atualmente se conta com a tecnologia para atender a demanda do mercado, o que incluí 83 provedores só para o mercado eólico.

Outra consideração é em torno das externalidades positivas que gerou o desenvolvimento do PROINFA para o setor elétrico já que, quando o sistema hidrelétrico está no período de seca, o ONS não se vê impelido a despachar usinas térmicas, pois é possível acudir ás usinas de energia renovável que estão conectadas ao Sistema Interligado Nacional SIN. Isso gera um impacto econômico muito importante no mercado energético, pois os encargos do sistema diminuem drasticamente quando não se despacham usinas térmicas o que reflexa um impacto na diminuição das emissões de $\mathrm{CO} 2$.

Satisfeitas as metas da primeira fase em termos de contratação da capacidade instalada de energias renováveis pode se afirmar que o arcabouço regulatório foi ajustado no sentido de reformular o objetivo do programa. Inicialmente para a segunda fase esperava-se que a oferta de energias renováveis cobrisse pelo menos o 10 


\subsubsection{Suporte financeiro do PROINFA}

Os custos que derivados do PROINFA no sistema energético brasileiro são rateados percentualmente entre todos os consumidores do sistema interligado nacional, as cotas de custeio do programa são calculadas pela ANEEL que as publica anualmente em novembro. Desta conta se eximem os consumidores de baixa renda. Todo o qual pode ser verificado no Plano Plurianual do PROINFA que é elaborado pela Eletrobrás segundo a atribuição legal contida no decreto 5.025 de 2004. Este plano conta com a homologação da ANEEL, documento que aborda a comercialização de energia, o preço desta energia para cada fonte alternativa, o pagamento dos contratos de compra e venta que inclui a energia contratada, a parcela de ajuste, os montantes anuais de energia que serão contratados cada ano e o custeio do programa.

Em muitos casos o preço da energia não mantém uma correlação com seu custo verdadeiro de produção (AUTHOR, 2014b), isso depende dos suportes institucionais de cada fonte de geração. As fontes convencionais costumam ter bastantes arranjos regulatórios e incentivos, como subsídios, e o leque das renováveis até agora, abrindo espaço para ganhar maior competitividade. No cenário de concorrência na geração de energia renovável se compete pela presença no mercado através de preços competitivos. Com as constantes inovações tecnológicas para as energias renováveis e em especial a energia eólica, pode ser auferida uma importante redução de custos tanto no processo de geração de energia alternativa quanto na operação e manutenção, o que redunda no favorecimento do custo final do investimento e imediatamente leva a uma queda no custo unitário de energia por kWh.

O PROINFA emergiu como um eficiente estímulo para atrair investimentos do setor privado para o mercado energético das energias renováveis para tanto, dando aos empreendedores as condições de segurança para poder investir. $O$ apoio institucional do tem sido fundamental para o avanço dos projetos de energias renováveis, um exemplo disso é o programa de apoio a investimentos em fontes alternativas de energia elétrica do Banco Nacional de Desenvolvimento BNDS, que abriu linhas de credito para este tipo de empreendimento, contemplando o financiamento de até $80 \%$ dos investimentos requeridos. Só ficando sem respaldo de crédito os investimentos que se encontrem na categoria de bens e serviços importados e a aquisição de terrenos. 
Entre as vantagens destes créditos esta a isenção de pagamento de juros durante a construção do empreendimento, a amortização por dez anos e a carência de seis meses após entrada em operação comercial da usina.

No momento da elaboração e desenho normativo dos programas de políticas públicas referentes às energias alternativas logicamente o governo considera o aspecto do financiamento, até por que o objetivo é atrair investimento do capital privado, mas isso também acontece quando existe facilidade para ter acesso aos créditos. O BNDES participou das discussões prévias à estruturação do PROINFA, e tem oferecido o apoio para o desenvolvimento das fontes renováveis.

As políticas de financiamento que estão em consonância com as políticas públicas em matéria de energia elétrica, de diversificação das fontes e universalização do serviço de energia, tiveram um montante para financiamento de $\mathrm{R} \$ 5.5$ bilhões para a primeira fase. No desenvolvimento do programa, as linhas de financiamento do BNDES sofreram alterações para melhoras nas condições para os empreendedores, modificando a porcentagem de participação do financiamento de 70\% para $80 \%$, ampliando o prazo de amortização máximo de 10 para 12 anos; garantias novas, e a prorrogação do prazo para iniciar a pagar as parcelas para seis meses depois da entrada em operação comercial. Também conta com facilidade para aceder a crédito via BID, BIRD, International Finance Corporation (IFC), Global Environment Facility (GEF), Energy Sector Management Program (ESMAP) (AUTHOR, 2014b).

No referente ao orçamento público, a parcela que Ihe é conferida ao PROINFA esta enquadrada na função de energia elétrica e é a ANEEL a unidade responsável pelo seu cumprimento, embora uma porção do dinheiro seja administrado pela Eletrobrás. Também deve ser considerado que nas universidades brasileiras também se faz uma pesquisa constante para o desenvolvimento de energias renováveis, então há uma fração do orçamento de educação que está orientada ao apoio do avanço tecnológico, regulatório, econômico e jurídico nesta matéria.

O suporte legal encontra-se na Lei $n^{\circ} 10.438$, de 26 de abril de 2002, Decreto no 4.541, de 23 de dezembro de 2002 e Acórdão n 3.389/2012-Plenário TCU. E a ação orçamentária consiste em efetuar a transferência de recursos provenientes dos pagamentos anuais realizados a título de uso de bem público e das multas aplicadas 
pela ANEEL a concessionárias, permissionárias e autorizadas para a Conta de Desenvolvimento Energético (AUTHOR, 2014a). Tal como consta na Lei orçamentária para 2014, mas os recursos provenientes desta ação orçamentária são compartilhados com o Programa de Universalização do Serviço de Energia Elétrica - Luz para Todos.

\subsubsection{Analise dos riscos na participação do PROINFA}

Na planificação também é importante considerar os riscos aos que se submetem os investidores que vão garantir a efetividade do programa de políticas públicas das energias renováveis, para tanto se identificam e analisam a seguir os riscos a que se vêm expostos. Com a ajuda dos programas atuais de simulação é facilmente identificável os riscos financeiros aos que se encontram expostos os investidores e com isso se diminui a probabilidade de que se entre no mercado com expectativas falsas. Tudo contribui para que o processo de participação seja mais objetivo e tenda a ter resultados satisfatórios para o capital privado que participa e para incrementar a transparência nos procedimentos são diligenciados pelo governo.

A projeção financeira deve incluir o cálculo da capacidade instalada e a energia assegurada e contratada com o preço de venda no mercado. Pelo fato de ter a venda de energia assegurada pela Eletrobrás que garante o pagamento da energia contratada, então não existe risco de liquidez de mercado (TIPOS. . ., 2017), este critério se aplica para todas as fontes de energia que participam do PROINFA. No que tange ao risco legal pode-se afirmar que como os contratos têm garantia na legislação, eles se encontram plenamente amparados para seu cumprimento, assim como as instituições jurídicas que permitem seu desenvolvimento. As modificações dos incentivos regulatórios, que tem sido efetuado no transcurso da implementação das políticas públicas das energias renováveis receberam o auxílio do direito como categoria do conhecimento que oferece segurança institucional e "que contribuem para executar ou mesmo aperfeiçoar tais políticas, mitigando suas disfunções e aumentando sua efetividade e eficácia" (COUTINHO, 2013).

O único risco a que se encontram expostas as energias alternativas é o risco operacional, pois depende de adequação tecnológica que permita dar cumprimento 
à capacidade instalada e aos compromissos contratuais derivados da execução dos contratos de compra e venda de energia junto a Eletrobrás.

\subsubsection{Principais críticas ao PROINFA}

Na projeção do PROINFA existiram várias barreiras para a entrada no mercado das fontes renováveis, que deviam ser trabalhadas para aumentar a eficácia do programa. Entre as expectativas a ser superadas estavam a falta de financiamento de longo prazo, a falta de motivação política e a abrangência de um processo mais inclusivo e participativo da cidadania, a ausência de tecnologia nacional e os altos custos da tecnologia para as fontes renováveis. Contudo, em termos gerais quando se revisa o avanço das políticas públicas para energias renováveis se observa como está sendo institucionalizada a necessidade de diversificar a matriz energética, com um panorama que apresenta bases jurídicas e econômicas de bastante solidez que tem aberto o mercado para as fontes renováveis.

Deve se considerar que apesar de que exista uma ampla gama de energias renovável, no PROINFA somente se está tratando de três dessas fontes, pelo que uma das suas principais críticas é não ter incluído outras energias renováveis no programa de incentivo as fontes alternativas e a energia do mar e a fotovoltaica entre outros. Decisão que possivelmente foi adotada pelos altos custos associados a tecnologias que se requerem para explorá-las, mesmo assim, é pertinente começar a trabalhar políticas públicas para as energias renováveis que não foram inseridas no PROINFA.

No que tange ao cumprimento dos contratos também existem algumas irregularidades, segundo observa Riscoti não todas as obrigações contratuais derivadas do PROINFA surtiram efeitos jurídicos, devido a que o modelo apresentava inconsistências ao "outorgar contratos que eram repassados e negociados mediante ganhos de taxas de desenvolvedor para investidores" (RISCOTI, 2011).

Como se tratava de um estímulo às energias renováveis que englobam três tecnologias diferentes na mesma política pública, como foram as $\mathrm{PCH}$, biomassa e eólica, não foi advertido que para esta última a projeção da tarifa devia incluir o fator de capacidade do Brasil nas suas diferentes regiões, pois este fator está diretamente vinculado a eficiência da geração eólica e a tarifa. Na Alemanha, por exemplo, quando se supera 
30

Evidenciou-se na primeira chamada pública a contratar o programa foi insuficiente para incentivar a biomassa pois da meta dos 1.100 MW se apresentaram projetos equivalentes a $995 \mathrm{MW}$, entanto que para energia eólica foi insuficiente pois era preciso ter um plano mais abrangente e ambicioso pois existia uma energia remanescente, já que os projetos apresentados nesta oportunidade chegaram aos $3.681 \mathrm{MW}$.

\subsubsection{Instrumentos jurídicos que contribuem com o desenvolvimento da fonte eólica}

Quando se ordena conhecimento técnico e jurídico o resultado é mais eficiente para abordar políticas públicas. O sistema energético não é alheio a este esquema de abordar a complexidade do problema. Por trás da escolha da diversificação da fonte se encontram princípios como a preservação da continuidade do serviço e a confiabilidade do sistema elétrico e para estes princípios existe uma proteção jurídica e técnica.

\subsubsection{Leilões e sua eficiência para incentivar a energia eólica}

Os leilões para energias renováveis são mecanismos de mercado que correspondem a um estágio mais evoluído da inserção de este tipo de tecnologia de geração na matriz do setor elétrico, já que servem como indicador que evidencia sua maturidade. Uma vez superadas as etapas inicias de incentivos desenvolvidos como políticas públicas desde incentivos tributários, FIT e tarifas Premium, as energias renováveis se vêm abocadas a responder à concorrência no mercado. Isso indica que as quando se chega ao estagio dos leilões as fontes renováveis respondem à expectativa do Estado de diversificar a matriz elétrica e às exigências da concorrência no mercado, mediante tarifas cada vez mais próximas às da energia convencional. Existem diferentes tipos de leilões entre os quais um específico para fontes alternativas para incentivar a participação destas fontes na Matriz Energética do Brasil, este tipo de leilão foi instituído pelo Decreto No. 6.049 de 2007.

Os leilões contribuem na estruturação de um ambiente mais competitivo entre as diferentes energias renováveis, se efetuam na Câmera de Comercialização de Energia 
por delegação da ANEEL e constituem um importante ambiente de negociação de energia no Brasil. Adicionalmente, a figura do leilão é o mecanismo para incentivar a contratação de energia renovável no ambiente de contratação regulada, com o intuito de ter um mercado energético mais eficiente, e se realizam rodadas onde a menor tarifa é a vencedora do certame. Neste ponto do desenvolvimento do PROINFA se observa um mercado energético muito mais consolidado com regras jurídicas claras, e um sistema de incentivos que permitem a competição das fontes convencionais com as renováveis. Mostra de esta maturidade é a evolução do preço do MWh como se pode ver na figura 2 ??

No Brasil estão amplamente desenvolvidos os leilões como instrumento de mercado para energias renováveis nos quais obviamente pode participar a energia eólica, do qual se derivam contratos de comercialização de energia. A normatividade que se aplica a estes leilões é a Lei $n^{\circ} 10.848$, de 2004, da Lei no 11.488, de 15 de junho de 2007, do Decreto $n^{\circ} 5.163$, de 30 de julho de 2004, o Decreto $n^{\circ} 6.353$, de 16 de janeiro de 2008, as Portarias MME no 178, de 28 de maio de 2013, no 132, de 25 de abril de 2013, $n^{\circ} 29$, de 28 de janeiro de 2011, da Resolução Normativa ${ }^{\circ} 337$, de 11 de novembro de 2008.

A possibilidade de que as energias renováveis compitam entre si, sem importar a tecnologia renovável, ou que compitam com a energia convencional é ainda um assunto do desenho dos leilões brasileiros que não apresenta um suficiente suporte técnico que explique e justifique a conformação das tecnologias que vão a participar nos leilões.

\subsubsection{A propósito das energias distribuídas autoprodutores e produtores in- dependentes}

Um aspecto que merece referência são as figuras de autoprodutor e de produtor independente de energia elétrica, pois têm sido fundamentais para impulsionar as fontes renováveis de energia. Assim como a garantia de livre acesso às redes de transmissão e distribuição para ter o respaldo do Sistema Interligado Nacional SIN se o seu sistema apresenta alguma falha ou no caso de querer exportar o excesso de energia. No caso do autoprodutor ou produtor independente se aplica o previsto no Decreto No. 2.003 de 1996 e correspondem a esta categoria os que tiverem as 
condições estipuladas no artigo 2 a saber:

Art. $2^{\circ}$ Para fins do disposto neste Decreto, considera-se: I - Produtor Independente de Energia Elétrica, a pessoa jurídica ou empresas reunidas em consórcio que recebam concessão ou autorização para produzir energia elétrica destinada ao comércio de toda ou parte da energia produzida, por sua conta e risco; II - Autoprodutor de Energia Elétrica, a pessoa física ou jurídica ou empresas reunidas em consórcio que recebam concessão ou autorização para produzir energia elétrica destinada ao seu uso exclusivo.

\subsubsection{A autorização administrativa}

Os empreendimentos de energia renovável requerem outorga de autorizações administrativas para sua operação. A outorga da autorização encontra-se disciplinado na resolução pela ANEEL e o requerimento é tramitado na Superintendência de Concessões e Autorizações de Geração. Entre os requerimentos e dependendo da envergadura do projeto a geradora deve ter: O Estudo do impacto ambiental (EIA), Relatório de Impacto Ambiental (RIMA) ou estúdio ambiental formalmente requerido pelo órgão ambiental conforme a legislação específica de meio ambiente; o projeto básico; o resultado do ensaio de comissionamento; e o histórico atualizado das medições de anemométricas e climatológicas ${ }^{1}$

Com efeito, de determinar o regime jurídico aplicável, na geração de energia se classificam as usinas dependendo da fonte e da sua capacidade de geração como se verá mais adiante. A autorização que dentro da doutrina do direito público se classifica como um ato administrativo de espécie, e dentro desta subclassificação a geração de energia eólica poderíamos rotulá-la como uma autorização de serviço público. Este ato da administração pública configura-se como um ato unilateral, precário e discricionário. Afastando-se um pouco do que sinaliza a doutrina, em matéria das autorizações que requer a energia elétrica há um restringido espaço para a discricionariedade, já que se o gerador se sujeita a o que contempla a normatividade para sua entrada em

\footnotetext{
${ }^{1}$ As medições anemométricas são as que determinam o potencial eólico, são efetuadas pelo empreendedor vencedor dos leilões de energia eólica e devem ajustar-se as instruções gerais que Aneel determina mediante nota técnica e em observância da Portaria do MME No. 29, de 28 de janeiro de 2011. Estas medições são fundamentais para o planejamento, operação e integração dos parques eólicos ao sistema elétrico nacional.
} 
operação decorre necessariamente sua aprovação. Em outro ponto que se afasta da doutrina é na condição de precariedade do título, toda vez que estas autorizações têm o prazo de vigência, o que segundo a doutrina obedece a uma autorização qualificada (MARQUES, 2009).

Para a energia eólica, é relevante fazer referência a que existem condiciones tecnológicas que ainda encontram-se em desenvolvimento, e constitui uma assimetria de informação no momento de tomada de decisão dos órgãos do governo. Esse risco que assume o Estado no processo de tomada de decisão dos incentivos deve ser ponderado para o processo de implementação, de tal forma que se contemplem as possibilidades de ajustes à política em consideração aos avanços tecnológicos. Isso é relevante na medida em que em matéria de direito administrativo a confiança legitima do administrado nas decisões dos órgãos administrativos deve ser preservada.

Em consequência, as autorizações administrativas que materializam a aplicação de um determinado incentivo beneficia-se do princípio de segurança jurídica, o que garante para o investidor em energias renováveis a estabilidade na decisão da administração. Mas por outra parte, encontra-se a necessidade da administração pública de trasladar a eficiência dos processos produtivos do setor elétrico às tarifas, aos usuários finais e em últimas ao sistema elétrico em geral, o que lhe outorga à administração pública a faculdade de alterar as decisões de incentivos, mas sem descuidar a segurança jurídica das decisões que consolidaram direitos para os investidores.

Particularmente considero que se requer um incentivo maior para a inovação tecnologia das energias renováveis para o qual deveria existir uma parcela do orçamento público dedicado exclusivamente a pesquisa e desenvolvimento da tecnologia para auferir maiores ganhos na potência instalada dos projetos de energias renováveis. Neste mesmo sentido, também o programa carece da estruturação para a capacitação das comunidades onde se localizam os projetos de energia renovável, já que estes projetos são de vital importância em regiões isoladas que não pertencem ao sistema interligado nacional.

É sabido que o PROINFA é um programa de longo prazo, e que vai sofrendo alterações paulatinas de acordo com as necessidades para seu avanço e segundo os parâmetros de incrementalismo com o que se devem trabalhar as políticas públicas, 
não obstante devem existir maiores ações de curto prazo na procura de fazer menos lento o caminho para a diversificação da matriz energética brasileira. Os indicadores apontados na tabela 1 podem servir para que as decisões políticas tenham variáveis relevantes para implementar de forma incremental as mudanças significativas (LINDBLOM, 2009). Tornando mais eficiente o processo da decisão no sentido de ter clareza sobre as metas e valores que se plasmam nas políticas púbicas que afetam as energias renováveis.

O programa carece de regras claras para a tramitação dos licenciamentos ambientais necessários para a construção e a operação comercial, isso foi um dos aspectos que contribuíram para que se atrasaram a primeira fase do programa. Essas autorizações administrativas embora previstas de maneira genérica no programa não foram consideradas para efeitos de contar com um cronograma mais aproximado à realidade.

Ainda existem incentivos regulatórios que não foram explorados no Brasil e que em outras latitudes já tiveram sucesso para as energias renováveis como é o casso do pagamento por capacidade no qual os geradores de energias renováveis recebem o que poderia considerar um subsídio (MOYA, 2006). Este incentivo foi implementado pela Alemanha concretamente para a fonte de energia eólica.

$\mathrm{Na}$ análise ambiental estima-se que de uma parte se tenha a necessidade do governo de consolidar uma economia que evite o efeito estufa com a redução de dióxido de carbono o qual a energia eólica é absolutamente compatível e de outra parte, o fato de que a energia eólica pode gerar um prejuízo paisagístico nas áreas com elevado potencial eólico onde se desenvolvem os projetos. Certamente, dentro do patrimônio nacional do Brasil encontra-se o patrimônio paisagístico que merece especial proteção, atualmente não se tem nenhuma referência jurisprudencial sobre o tema, mas é possível que no futuro existam controvérsias neste sentido, como acontece atualmente na Europa. Isso decorre de que se bem é certo a energia eólica pode ser catalogada como limpa e de baixo impacto ambiental, isso não inclui a condição de que também apresente algumas externalidades negativas, entre as que se encontra 0 comprometimento à paisagem. 


\section{CARACTERIZAÇÃO DO RECURSO EÓLICO COM A METODOLOGIA DO PLANEJAMENTO INTEGRADO DE RECURSOS}

O objetivo do presente capítulo é a caracterização do recurso eólico como fonte de energia, tanto da oferta quanto da demanda dentro da matriz energética brasileira com a análise metodológica que permite a Planejamento Integrado de Recursos Energéticos (M.UDAETA, ). Efetuou-se a construção de dois cenários energéticos para a fonte de energia eólica, o primeiro deles é um cenário tendencial, considerando as dimensões social, econômica, ambiental e política. No Cenário sustentável, é abordado o potencial de energia eólica como recursos renováveis e sue potencial para oferecer uma alternativa de desenvolvimento sustentável mediante a redução de emissões de CO2. Os cenários contem uma previsão de oferta e demanda para os próximos 50 anos.

Pretende-se delimitar os elementos mais relevantes dentro da oferta de energia eólica, e a partir deles estruturar um cenário tendencial e um cenário sustentável, tanto do consumo quanto da demanda de energia elétrica entre o período de 2012 ate 2062. Para tal propósito foram analisados os dados históricos de consumo por classes de serviço da Empresa de Pesquisa Energética EPE, os dados do IBGE sobre crescimento populacional. A tendência de crescimento de oferta de energia eólica foi projetada levando em consideração os dados extraídos do mercado atual e as projeções de crescimento do documento Plano Nacional de Energia - PNE 2030, MME, 2007 e do documento de Green Peace, Revolução Energética, assim como também as informações da associação brasileira de energia eólica ABEEOLICA.

Salienta-se a relevância da dimensão política já que permite ter uma visualização das alternativas para tomada das decisões (BIAGUE, 2010), e considerando que a fonte eólica encontra-se em fase de desenvolvimento tecnológico, é preciso revisar aos Envolvidos e Interessados e seus interesses concretos no desenvolvimento desta fonte de energia. Em razão a que cabe a eles influenciar a adequada elaboração das políticas públicas para levar adiante os propósitos de exploração do recurso eólico.

Para a elaboração das políticas públicas e energéticas que abranjam cada vez mais os recursos renováveis é indispensável ter clareza das ferramentas políticas que 
permitam o crescimento de um determinado recurso energético no longo prazo. Igualmente deve ser analisado o conjunto normativo integrado pelos documentos emitidos pelo legislativo e pela administração pública, tanto da ordem federal quanto da estadual. Estes fatores oferecem limitativos tanto para promover o avanço como para restringir o uso efetivo do potencial energético do respectivo recurso. Pelo tanto, a importância desta dimensão consiste em que tem a capacidade de influenciar o adequado desenvolvimento do recurso energético ou também de propiciar sua inviabilidade.

Igualmente, será abordada a análise dos incentivos para que os envolvidos e interessados contribuam no processo de consolidação de uma política energética sustentável e sua influência para estruturar incentivos para energia eólica como são o sistema de cotas, os leiloes, o sistema de preços e os subsídios, já que eles contribuem a abrir o mercado para as fontes renováveis e fazem efetiva a inserção do recurso eólico dentro da matriz energética.

A energia eólica é apresentada como uma interessante opção para as próximas décadas, o que deve ser acompanhado de avanços não só em aspectos de política energética e incentivos regulatórios e de mercado, mas também na esfera tecnológica para contribuir com eles à otimização e o amadurecimento do recurso eólico em termos de competitividade. Espera-se que com os avanços tecnológicos se tenham significativos aportes à eficiência energética e se consiga auferir dos equipamentos um melhor fator de capacidade, acorde com as condições dos ventos do Brasil, tudo isso em prol do desenvolvimento sustentável.

\subsubsection{Cenário tendencial para o recurso eólico}

O razão de ser deste cenário de referência é a verificação da evolução dos recursos energéticos do lado da demanda e da oferta, para o qual se parte da matriz energética atual e se efetua a projeção do aumento progressivo do consumo de energia, tendo como referência os valores históricos dos últimos 10 anos, com fundamento na informação que vem do aspecto político. Dentro da provisão da oferta especificamente para o recurso de fonte eólica considera-se a projeção de crescimento com os projetos que vão entrar em operação e o potencial eólico. 


\subsubsection{Previsão da oferta de energia eólica}

Tal como se encontra registrado no Plano de Expansão de Energia 2020 e o Plano Nacional de Energia 2030 (PLANO. .., 2007), se mantêm a previsão de aumento das fontes renováveis graças à contribuição das políticas públicas que incentivam o crescimento do mercado para estas fontes, preservando assim o interesse do governo e concretamente do setor elétrico em manter um desenvolvimento sustentável na geração de energia elétrica. Segundo a Empresa de Pesquisa Energética o Brasil é um dos países que menos emite gases na geração de energia elétrica, isso tende a melhorar com a entrada em operação de parques eólicos e as usinas de biomassa (PLANO..., 2014).

Na previsão da oferta de energia de fonte eólica considera-se a projeção de crescimento com o potencial eólico existente e os projetos que vão entrar em operação. Diversos estudos indicam que no Brasil os valores estimados são maiores que 60.000 MW, mas esta cifra não pode ser definida com precisão em razão da carência de informações sobre a superfície e as limitações que decorrem das metodologias utilizadas. Segundo os dados fornecidos pelo Atlas Eólico do Brasil (NADA, a), estima-se que o potencial eólico brasileiro medido a $50 \mathrm{~m}$ de altura é de $143 \mathrm{GW}$, ou praticamente 270TWh/ano, que é hoje a metade do consumo do país em energia elétrica.

Segundo o CRESESB Brasil conta com ventos bastante favoráveis que permitem a utilização de energia eólica principalmente no Nordeste, assim como também no litoral do estado de Rio Grande do Sul, e no litoral norte do Estado de Rio de Janeiro. O potencial eólico é determinado em função das informações sobre a velocidade e o regime dos ventos. Para que a fonte eólica seja aproveitável como recurso energético requer que sua densidade seja maior o igual a $500 \mathrm{~W} / \mathrm{m} 2$ a uma altura de $50 \mathrm{~m}$, com uma velocidade mínima de vento de 7 a 8 m/s (GRUBB; MEYER, ).

Com o fim de estabelecer o potencial eólico em uma determinada área geográfica é importante que se coletem dados sobre a velocidade do vento de forma periódica. Ponderando as variações do vento, sua direção, os parâmetros atmosféricos já que são estes indicadores determinantes da escolha do local para localizar as turbinas e da sua projeção de produtividade energética levanto em conta o fator de capacidade (FADIGAS; FARIA, 2011). 


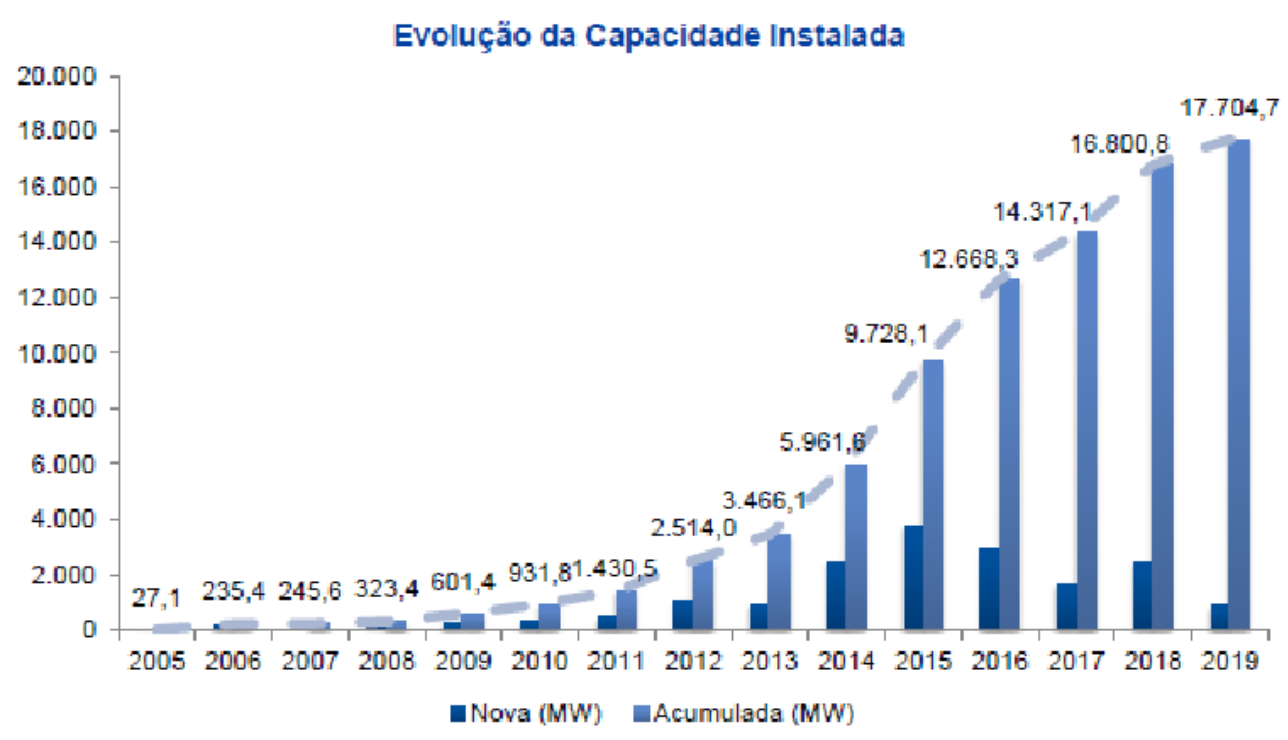

Figura 2 - Evolução da capacidade Instalada de Energia Eólica no Brasil (ABEEOLICA, 2011)

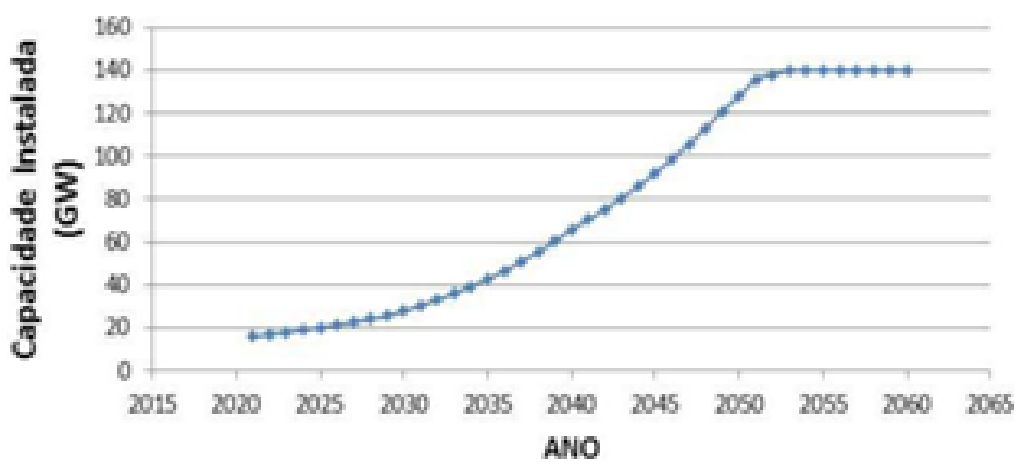

Figura 3 - Projeção do crescimento da Capacidade Instalada de Energia Eólica. Fonte: Elaboração própria

$\mathrm{Na}$ figura 2 se mostra a projeção da capacidade instalada a partir do ano 2021 até o ano 2060 com um considerável incremento. Isso corresponde à aplicação de políticas públicas que consagram a necessidade de limpar a matriz energética brasileira e tornar os preços destas fontes energéticas mais competitivos para permitir-lhes um crescimento dentro do mercado. Em 2013 o Brasil conta com 119 usinas de energia eólica o que representa uma capacidade instalada de $2.788 \mathrm{MW}$, a partir destes dados se projeta a seguinte capacidade instalada

A projeção dos dados da figura 3 correspondem às porcentagens de crescimento por décadas, levando em consideração fatores demográficos e econômicos que afetam diretamente a fonte energética objeto de estudo. A partir de 2021 estima-se que pelo aumento progressivo da capacidade instalada de energia eólica, ela ganhara um 
espaço cada vez maior dentro da matriz energética brasileira. Entre a década de 2020 a 2030 estima-se que o crescimento vai ser de 7\%, pela entrada em operação de parques eólicos.

Década 2030- 2040: Entre os anos 2030 a 2040 o crescimento da indústria eólica pode alcançar o $9 \%$, este crescimento da capacidade instalada obedece ao estimulo do governo mediante políticas públicas, incentivos regulatórios e normativos. Este crescimento também obedece ao desenvolvimento de tecnologias que permitam extrair o potencial eólico brasileiro considerando suas especificidades ambientais e meteorológicas. Assim como também à consolidação da pesquisa na matéria, integrando centros de pesquisa multidisciplinares, o que vai representar a inovação tecnológica da que vão ser auferidos ganhos de eficiência energética e otimização do fator de capacidade dos aerogeradores. Também se materializarão inovações que permitam maior precisão na medição do vento e obter certificados de qualidade dos aerogeradores.

De outra parte nesta década, a exploração do pré-sal projeta reservas que posicionarão ao Brasil no sexto maior produtor mundial de óleo no mundo como também no maior exportador de etanol do mundo. Neste contexto permite-se que se efetuem fortes investimentos em energia limpa dando-se preferência à fonte eólica sobre a biomassa.

Década 2040-2050: Como decorrência de analise da dimensão econômica onde se percebe o Brasil como um país com solides e estabilidade econômica a futuro, as políticas públicas nesta década permitiram a eficiente distribuição da renda que redundará na garantia de uma economia sustentável. O risco país continua sendo valorado pelas agencias internacionais de risco como grau de investimento seguro, o que permite continuar atraindo investimentos para empreendimentos de infraestrutura no Brasil.

$\mathrm{Na}$ década de 2040 a 2050 com um crescimento de $7 \%$ no final desta década esgotar-se-á o potencial eólico brasileiro chegando a $144 \mathrm{GW}$ de capacidade instalada, a partir de ali a capacidade instalada de energia eólica vai ser mantida. No cenário projetado por Green Peace Revolução Energética, estima-se para o ano 2050 que dentro da matriz elétrica as novas fontes renováveis que são a eólica (GREENPEACE, ), fotovoltaica, $\mathrm{PCH}$ e biomassa terão uma representação do $38 \%$ dentro da 
Tabela 2 - Porcentagem de participação de energia eólica no total de consumo de energia.

\begin{tabular}{|lcccc|}
\hline Ano & $\begin{array}{c}\text { Capacidade } \\
\text { instalada de } \\
\text { eólica (GW) }\end{array}$ & $\begin{array}{c}\text { Capacidade } \\
\text { instalada de } \\
\text { eólica (GWh) }\end{array}$ & $\begin{array}{c}\text { Consumo de } \\
\text { energia total (GWh) }\end{array}$ & $\begin{array}{c}\text { Porcentagem da } \\
\text { demanda atendida } \\
\text { por eólica (\%) }\end{array}$ \\
\hline 2021 & 16 & $140.160,0$ & 632.630 & 22 \\
2030 & 29,4 & $257.544,0$ & 973.093 & 26 \\
2040 & 69,6 & $609.696,0$ & 1.496 .785 & 41 \\
2050 & 137 & $1.200 .120,0$ & 2.302 .313 & 52 \\
2060 & 144 & $1.261 .440,0$ & 3.541 .355 & 36 \\
\hline
\end{tabular}

matriz energética Brasileira com 396 GW. Segundo os dados analisados do desenvolvimento da fonte eólica, esta terá atingido seu potencial em 2050 com 144 GW e a partir de ali conservara esse patamar. Tendo como referência que a capacidade instalada do Brasil vai aumentar aproximadamente 4 vezes até 2050 e partindo de 2013 com uma capacidade instalada de $124 \mathrm{GW}$, pode ser inferido que em 2050 teremos ao redor de 496 GW instalados, dos quais a energia eólica representaria um 29\% aproximadamente. A continuação na tabela 2 se estabelece a relação da demanda atendida pela energia eólica entre as décadas de 2020 até 2060, esta informação foi projetada com base na capacidade instalada de energia eólica da figura 2 e as projeções de consumo projetadas neste cenário na figura 6 :

\subsubsection{Fatores tecnológicos do recurso eólico}

A contribuição tecnológica é fundamental para continuar incentivando a expansão da capacidade de energia eólica. Embora o potencial eólico do Brasil este estimado perto dos $60.000 \mathrm{MW}$ (NADA, a). certamente no cenário do longo prazo os avanços tecnológicos poderiam ter impacto no aumento desta cifra. O desenvolvimento tecnológico pode estar presente em sistemas avançados de transmissão, melhor aerodinâmica, metodologias otimizadas para a operação das turbinas que permitam o melhor aproveitamento do recurso energético e melhoras na confiabilidade.

Segundo a nomenclatura da ANEEL que se classifica assim:

a. Pequeno porte - potência nominal menor ou igual a $500 \mathrm{~kW}$, normalmente utilizado em residências rurais, fazendas e aplicações remotas. 
b. Médio porte - potência nominal na faixa de 500 - $1000 \mathrm{~kW}$, sendo destinadas à utilização em pequenas comunidades, sistemas híbridos e geração distribuída.

c. Grande porte - potência nominal maior que $1 \mathrm{MW}$, sendo destinadas à utilização em parques eólicos e geração distribuída.

Adicionalmente, o controle de potencia das turbinas que afeta o aumento da potencia máxima gerada pode ser otimizada com o uso da tecnologia. Sendo assim, estimase que a potencia nominal chegue a ser de 4,5 MW nos próximos anos (ENERGIA..., 2012).

\subsubsection{Viabilidade financeira dos projetos de energia eólica}

Certamente, a energia eólica atualmente está atraindo fortes investidores tanto nacionais como internacionais. Desde o ano 2009 tem chegado ao Brasil $15 \mathrm{em}$ presas fabricantes de aerogeradores (ABEEOLICA, 2011). O Brasil está investindo fortemente na energia em parques eólicos devido à necessidade de ganhar mercado e ter cada vez mais demanda no mercado. Atualmente são importados $40 \%$ de equipamentos para geração eólica e é o país que mais está investindo em energia eólica no mundo, mas estima-se que os equipamentos serão fabricados totalmente no Brasil na próxima década.

Adicionalmente os investimentos em energia encontram-se privilegiados principalmente pelo fato de que o fator de capacidade dos projetos eólicos pode chegar até 0 $50 \%$, o que deixa ao Brasil por cima de países como Alemanha e Reino Unido nos quais o fator de capacidade não supera o $25 \%$. Evidencia-se que o fator de capacidade no Brasil pode oscilar entre o 27\% e 54\%. (ENERGIA..., 2012). Em decorrência dos investimentos em inovação tecnológica torna-se factível no ano 2030 a fabricação nacional das turbinas eólicas ou aerogeradores.

Geração de Empregos: A indústria eólica já possui hoje mais de 12 mil postos de trabalho na fabricação de aerogeradores e serão criados cerca de 20 mil empregos diretos na construção de parques eólicos até 2016, sendo muitos destes empregos com 
mão de obra local. No período todo serão 280.179 empregos diretos e indiretos acumulados até 2021, segundo a Abeeólica, sendo que a maior parte deles vem da fase de construção de parques eólicos. Adicionalmente se terá permanentemente a partir de este período a criação de 6.230 empregos nas áreas de operação e manutenção.

\subsubsection{Dimensão política do cenário}

O aspecto político não acostuma obedecer a nenhum modelo fixo, pelo qual representa uma avaliação subjetiva o que implica que neste aspecto está com uma enorme probabilidade de incerteza dentro do planejamento, mesmo assim requer ser avali-

ado, devido a sua enorme importância. É difícil, desde o ponto de vista metodológico efetuar uma avaliação quantitativa (BIAGUE, 2010). Mesmo assim o que pode ser considerado para avaliar quantitativamente a dimensão política é a análise das necessidades e interesses conhecidos pelos agentes políticos ou Envolvidos e Interessados que estão no panorama bem seja do lado da oferta ou do lado da demanda, sengundo se mostra na figura 4.

Os dados históricos são sem dúvida um ponto de referência para a construção do cenário, mas como o foco está centrado no aspecto político, que é bastante indeterminado e incerto, é necessário inserir uma perspectiva de eficiência do recurso, levando em conta a natureza do recurso energético em questão. Certamente os tomadores de decisões no contexto político vão ter que avaliar a conveniência da presença da energia eólica como recurso energético renovável dentro da matriz energética brasileira.

Grau de aceitação do Recurso: Um dos aspectos destacados dentro da dimensão política na figura 4 é o grau de aceitação do recurso, a energia eólica se beneficia cada vez mais do grau de aceitação entre os investidores desde que representem uma adequada taxa de retorno e de que se negociem preços no ambiente de contratação livre favoráveis e em condições de competitividade quando comparados com outras tecnologias. Para a sociedade em sua qualidade de consumidor a aceitação do recurso claramente depende de tarifas competitivas para o consumidor final, não obstante que na medida em que cresça o interesse de ter energia que não provenha de combustíveis fosseis também incrementará a favorecimento na sociedade com 


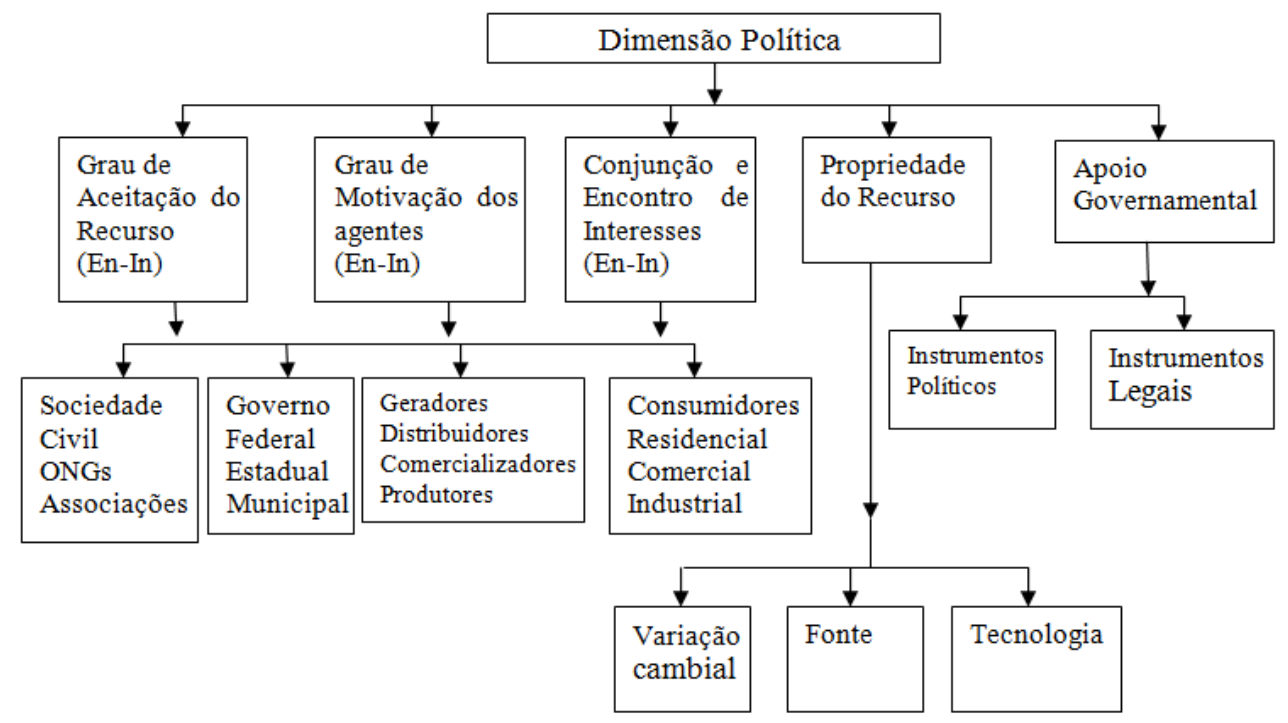

Figura 4 - Fluxograma dos atributos e subatributos da dimensão política.

relação à energia eólica.

Certamente, a modicidade tarifaria é um princípio norteador dentro da Escola dos Serviços Públicos e deve entender-se que esta condicionada pela eficiente gestão dos prestadores de serviços públicos (SHIRATO, 2012). Na medida em que a otimização dos recursos com os quais se realiza a prestação do serviço seja eficientemente projetados redunda em beneficio da taxa de retorno do respectivo agente. Na linha de argumentação da modicidade tarifaria também pode ser decisivo a elaboração de políticas públicas que permitam a inserção de subsídios cruzados entre as diferentes classes de consumidores.

Em quanto à sociedade em geral e suas organizações ONG, a fonte eólica também conta com um alto nível de aceitação, pelas suas características de ser uma fonte renovável; quanto maior espaço ganhe na matriz energética vai conseguir viabilizar um modelo de desenvolvimento ambiental sustentável.

Infere-se então, que uma motivação para os envolvidos e interessados que se encontram do lado da demanda de energia elétrica é a preservação dos princípios que norteiam a prestação dos serviços públicos, tais como continuidade do serviço, modicidade tarifaria e universalização. O respeito e garantia por estes princípios permite o incremento do nível da qualidade de vida, fato que concerne a todos os envolvidos e interessados, devido a que eles são um elemento finalístico para preservar os direitos fundamentais e satisfazer necessidades básicas dos usuários finais. Pelo qual, 
justifica-se a obrigação do Estado de velar por sua garantia. Não obstante, que seja uma obrigação do Estado não é óbice para a existência da concorrência pelo e no mercado.

Grau de Motivação dos agentes: Certamente, a motivação do governo com a implementação dos projetos eólicos é fundamentalmente limpar a matriz energética, e paralelo a isso ampliar o leque de oferta de energia elétrica, para isso precisa harmonizar os interesses dos investidos que pretendem investir no setor e os interesses da sociedade em geral. A referência para estes envolvidos e interessados é uma política energética clara e consistente com os resultados almejados por eles e as realidades dos recursos disponíveis. No momento atual o recurso eólico é considerado bastante atrativo para os investidores tanto nacionais como estrangeiros, o que viabiliza o crescimento da oferta com empreendimentos de usinas eólicas e a ampliação da participação do mercado a traves de leilões.

No referente à motivação para a sociedade em geral são dois fatores fundamentalmente, um deles é contar com maiores possibilidades de empregos e outro é a opção de aceder a tarifas de energia mais módicas em decorrência da variedade de oferta de energia e o fato de não ter que gerar um despacho das térmicas nos períodos de restrições das hidrelétricas.

A motivação dos consumidores residenciais em adquirir energia eólica por meio de incentivos fiscais para projetos eólicos de pequeno e médio porte para os consumidores finais. Assim como também contemplando uma regulação energética que considere a possibilidade de exportar a energia elétrica excedente ao sistema interconectado nacional.

Entre os instrumentos políticos para incentivar a demanda de energia eólica no Brasil podem incluir-se os seguintes:

- Redução da taxa de juros.

- Credito para adquirir aerogeradores de pequeno e médio porte para os usuários finais de energia elétrica.

- Investimentos isentos de Imposto sobre Circulação de Mercadorias e Serviços e 
Imposto - ICMS e Imposto sobre Produtos Industrializados - IPI.

- Liberdade para escolher a fonte energética que vai ser usada pelo consumidor final.

- Diminuição da demanda reprimida para adquirir bens de consumo energético.

Conjunção e Encontro de Interesses: Os Envolvidos e Interessados para levar a desenvolver projetos de energia limpa, devem estar plenamente identificados a fim de propor uma estrutura conjunta de políticas públicas que incluam aos vigilantes políticos e que avalie seus interesses. A sociedade, o governo nos deferentes níveis, federal, estadual e municipal apresentam o interesse conjunto de obter recursos energéticos e de efetuar sobre eles um adequado gerenciamento.

Certamente, o fato de ter uma matriz energética mais limpa localiza-se na esfera jurídica e política pelo fato de ser um bem ou recurso de interesse público. Que se bem é certo é um princípio jurídico indeterminado no contesto do Estado social e democrático de Direito, deve atribuir-se a ele a funcionalidade diretiva dentro da vida do Estado contemporâneo, principalmente materializados em políticas públicas, leis e regulamentações.

Quando se catalogam os recursos naturais e energéticos como objetos passíveis de interesse público, mesmo que essa conceituação resulte quase intangível num primeiro momento é o inicio para que cobre vida jurídica e seja protegida em todas as instâncias da administração pública, da jurisdição e na legislação.

Propriedade do Recurso: Fruto das parcerias público privadas (PPP) se construíram empreendimentos de infraestrutura onde convergem os interesses e as necessidades do setor público e privado a través de instrumentos jurídicos como são as parcerias público privadas.

Salienta-se que no que tange às parcerias público privadas foram contempladas no artigo 4 as diretrizes gerais, nos seguintes termos:

I - eficiência no cumprimento das missões de Estado e no emprego dos recursos da sociedade; 
II - respeito aos interesses e direitos dos destinatários dos serviços e dos entes privados incumbidos da sua execução;

III - indelegabilidade das funções de regulação, jurisdicional, do exercício do poder de polícia e de outras atividades exclusivas do Estado;

IV - responsabilidade fiscal na celebração e execução das parcerias;

V - transparência dos procedimentos e das decisões;

$\mathrm{VI}$ - repartição objetiva de riscos entre as partes;

VII - sustentabilidade financeira e vantagens socioeconômicas dos projetos de parceria.

Igualmente, podem ser construídos empreendimentos de energia eólica a partir do marco jurídico oferecido pelo contrato de concessão, regido pela Lei 8.987 de 1995. Neste tipo de contratação administrativa, encontra-se previsto que os bens com os quais se realize a prestação de serviços públicos, são considerados bens públicos e por tanto são reversíveis ao poder público ao final da concessão. Para tal propósito, contempla o parágrafo 1ro artigo 35 da Lei 8.987 de 1995 que, uma vez extinta a concessão retornam ao poder concedente todos os bens reversíveis, direitos e privilégios transferidos ao concessionário conforme previsto no edital e estabelecido no contrato.

\subsubsection{Previsão de demanda}

A projeção de crescimento de consumo de energia elétrica é 6 GW ao ano de acordo com a Empresa de Pesquisa Energética EPE. Para projetar a 50 anos a demanda de energia elétrica neste cenário foram considerados o crescimento populacional e o crescimento do consumo histórico elaborado pela EPE para cada classe de serviço nos últimos dez anos.

\subsubsection{Crescimento Populacional}

Segundo os dados fornecidos pelo IBGE no período 1950-1960, a taxa de crescimento da população recuou de 3,04\% ao ano para 1,05\% em 2008. Já para o período de 2050 encontra-se previsto que a taxa de crescimento cairá para $0,291 \%$, o que representa uma população de 215,3 milhões de habitantes (??). Continuando com esta 


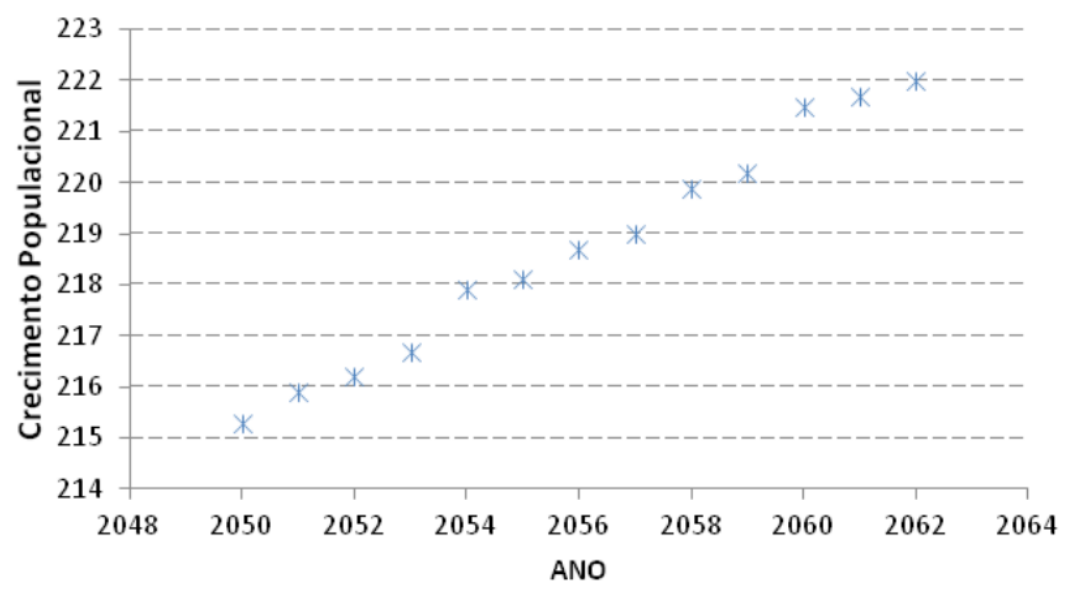

Figura 5 - Crescimento populacional (fonte: elaboração própria baseado nos dados do IBGE).

previsão de incremento porcentual da população estima-se que para 2060 a população do Brasil será de 221 milhões de habitantes aproximadamente, como apresentado na figura 5.

De outra parte, o crescimento porcentual que ano a ano experimenta o país se reflete no consumo de energia tanto pelo aumento dos lugares de consumo quanto pelo aumento de consumo individual de energia (BIAGUE, 2010).

\subsubsection{Consumo de energia elétrica por classe de serviço}

Para efetuar a projeção A evolução do consumo de energia que se apresenta na tabela 3 ponto de referência a partir do qual se projetam os dados apresentados neste cenário para as classes de serviço residencial, comercial, industrial e outros. Nesta tabela estão expostos os históricos de consumo entre os anos de 1995 e 2012 e as porcentagens de crescimento ao longo deles.

A demanda de energia elétrica dentro do cenário vai ser projetada considerando os dados anteriores, estabelecendo a media dos últimos dez anos do crescimento de consumo para cada classe de serviço, tal como se evidencia na figura 6. 


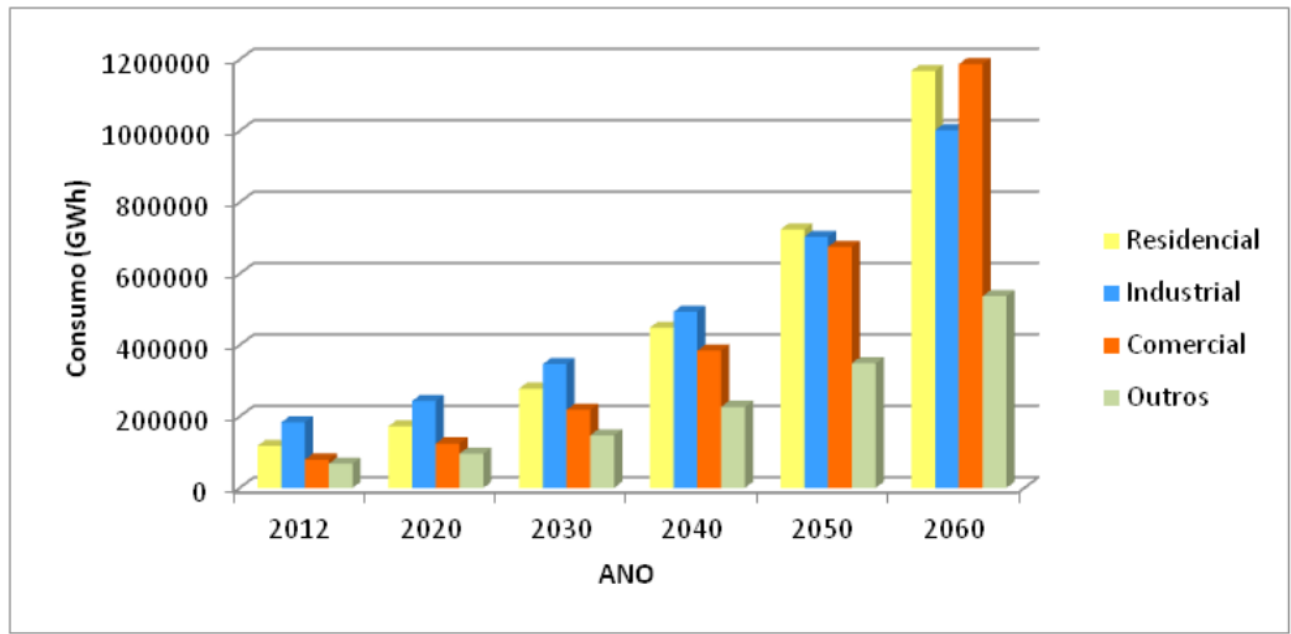

Figura 6 - Projeção de Consumo por Classe de Serviço 2012- 2060 (fonte: elaboração própria). 
Tabela 3 - Evolução do consumo de energia desde 1995 até 2012.

\begin{tabular}{|c|c|c|c|c|c|c|c|c|c|c|c|c|c|c|c|c|c|c|}
\hline $\begin{array}{l}\text { Consumo } \\
\text { (GWh) }\end{array}$ & 1995 & 1996 & 1997 & 1998 & 1999 & 2000 & 2001 & 2002 & 2003 & 2004 & 2005 & 2006 & 2007 & 2008 & 2009 & 2010 & 2011 & $2012^{*}$ \\
\hline Brasil & 243.074 & 257.330 & 273.280 & 284.522 & 292.188 & 307.529 & 283.257 & 293.226 & 306.987 & 329.707 & 344.284 & 356.129 & 377.030 & 388.472 & 384.306 & 415.683 & 433.034 & 448.276 \\
\hline Residencial & 63.576 & 68.581 & 74.089 & 79.340 & 81.291 & 83.613 & 73.622 & 72.718 & 76.162 & 78.470 & 82.644 & 85.784 & 89.885 & 94.746 & 100.776 & 107.215 & 111.971 & 117.567 \\
\hline Industrial & 111.626 & 117.128 & 121.717 & 121.979 & 123.893 & 131.278 & 122.539 & 130.927 & 136.221 & 154.163 & 158.610 & 163.180 & 174.369 & 175.834 & 161.799 & 179.478 & 183.576 & 183.471 \\
\hline Comercial & 32.276 & 34.388 & 38.198 & 41.544 & 43.588 & 47.626 & 44.434 & 45.222 & 47.531 & 49.686 & 53.035 & 55.369 & 58.647 & 61.813 & 65.255 & 69.170 & 73.482 & 79.286 \\
\hline Outros & 35.596 & 37.234 & 39.276 & 41.659 & 43.416 & 45.011 & 42.663 & 44.359 & 47.073 & 47.389 & 49.995 & 51.796 & 54.129 & 56.079 & 56.477 & 59.820 & 64.006 & 67.952 \\
\hline $\begin{array}{l}\text { Crescimento } \\
(\%)\end{array}$ & 1995 & 1996 & 1997 & 1998 & 1999 & 2000 & 2001 & 2002 & 2003 & 2004 & 2005 & 2006 & 2007 & 2008 & 2009 & 2010 & 2011 & $2012^{*}$ \\
\hline Brasil & 7,8 & 5,9 & 6,2 & 4,1 & 2,7 & 5,3 & $-7,9$ & 3,5 & 4,7 & 7,4 & 4,4 & 3,4 & 5,9 & 3,0 & $-1,1$ & 8,2 & 4,2 & 3,5 \\
\hline Residencial & 13,6 & 7,9 & 8,0 & 7,1 & 2,5 & 2,9 & $-11,9$ & $-1,2$ & 4,7 & 3,0 & 5,3 & 3,8 & 4,8 & 5,4 & 6,4 & 6,4 & 4,4 & 5,0 \\
\hline Industrial & 4,0 & 4,9 & 3,9 & 0,2 & 1,6 & 6,0 & $-6,7$ & 6,8 & 4,0 & 13,2 & 2,9 & 2,9 & 6,9 & 0,8 & $-8,0$ & 10,9 & 2,3 & $-0,1$ \\
\hline Comercial & 11,9 & 6,5 & 11,1 & 8,8 & 4,9 & 9,3 & $-6,7$ & 1,8 & 5,1 & 4,5 & 6,7 & 4,4 & 5,9 & 5,4 & 5,6 & 6,0 & 6,2 & 7,9 \\
\hline Outros & 6,7 & 4,6 & 5,5 & 6,1 & 4,2 & 3,7 & $-5,2$ & 4,0 & 6,1 & 0,7 & 5,5 & 3,6 & 4,5 & 3,6 & 0,7 & 5,9 & 7,0 & 6,2 \\
\hline
\end{tabular}




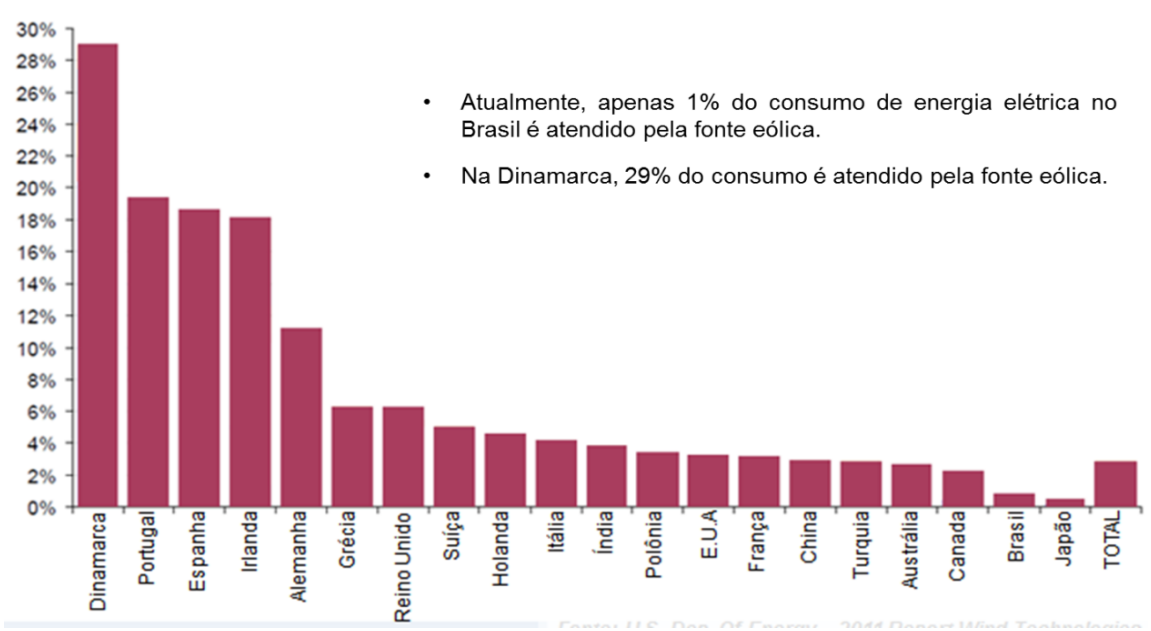

Figura 7 - Consumo atendido por energia eólica no mundo (fonte: ABEEOLICA).

Com fundamento nos dados da EPE dos 10 últimos anos de consumo por classe de serviço foi estabelecida a porcentagem de crescimento para os próximos 50 anos tendo como ponto de partida que na classe residencial a porcentagem é de $4,9 \%$, na industrial é de $3,6 \%$, na comercial é de $5,8 \%$ e outras é de $4,4 \%$. Isto leva a um crescimento no consumo de 448.276 GWh em 2012 a 3541.354GWh no 2060.

De outra parte, também é considerado que o consumo interno tem na próxima década uma queda da demanda reprimida devido à eliminação do Imposto sobre Produtos Industrializados (IPI) para produtos de uso residencial (geladeiras, maquinas de lavar, fogões, micro-ondas), e redução de mesmo importo para bens como carros.

Com relação à demanda de energia no mundo que é atendida pela fonte eólica, atualmente existem os seguintes dados apresentados na figura 7 .

\subsubsection{Cenário sustentável}

Por meio da analise dos dados provenientes da demanda e da oferta da energia eólica procura-se projetar o desenvolvimento sustentável que representa este recurso dentro da matriz energética e por um período de longo prazo. Assim, se tem como objetivo vislumbrar o aproveitamento de recursos energéticos e seus impactos com melhoras de eficiência no uso final e no uso das fontes de energia.

A energia eólica é considerada o recurso energético limpo e porem sustentável que projeta o maior crescimento a médio e longo prazo. Esse crescimento deve ser realizado com total harmonização entre a demanda e a oferta para obter um desen- 
volvimento sustentável.

A fonte de energia eólica como energia renovável vai ser candidata para se tornar um mecanismo de desenvolvimento limpo no Brasil. Vislumbrando que o Brasil consiga continuar aproximando-se à maturidade econômica, resulta plenamente viável a implementação de turbinas para geradores eólicos para o consumidor final nas diferentes classes de serviço, incluso para a residencial (edifícios, casas, áreas rurais) com preços competitivos e de fácil acesso que permitam um investimento seguro. Tudo o qual redunda em uma redução do aquecimento global acorde com o modelo de desenvolvimento econômico (??).

Evidencia-se uma perspectiva mais acorde ao modelo de desenvolvimento sustentável com o aumento crescente de fontes renováveis de energia com preponderância da fonte eólica. Tal como pode ser observado na figura 7, até 2021 as fontes renováveis ganharam um espaço de $20 \%$ dentro da matriz energética, representados em energia eólica, biomassa e pequenas centrais hidrelétricas.

Certamente o fato de que $85 \%$ da energia elétrica oferecida no país provenha do sistema hidroelétrico, significa que o pais esta exposto a sua natural sazonalidade, reduzindo com isso a confiabilidade geral no sistema. Em decorrência do anterior, é importante considerar a necessidade de complementar com outras fontes de energia de preferência renováveis. Principalmente por que como é um fato conhecido o déficit nos reservatórios hidroelétricos, nas atuais condições, significa que há que acionar as usinas térmicas, tal como aconteceu no ano 2012. Na figura 8 observa-se como no meio tempo as novas fontes renováveis ganharam espaço dentro da matriz energética em detrimento da energia hidrelétrica, o que permite uma maior diversidade das fontes no sistema elétrico brasileiro.

Partindo do gráfico da dimensão política, serão analisados dentro do cenário sustentável, os instrumentos políticos e os instrumentos legais com os quais conta a fonte de energia eólica para continuar crescendo dentro da matriz energética e sua contribuição no processo de limpá-la e diversificando as fontes.

Dentro do cenário sustentável se analisa a relação entre o incremento da oferta de energia eólica apresentado na figura 3 deste trabalho e a redução das emissões de $\mathrm{CO}_{2}$. Em decorrência da contratação que resultou dos leilões de energia eólica 

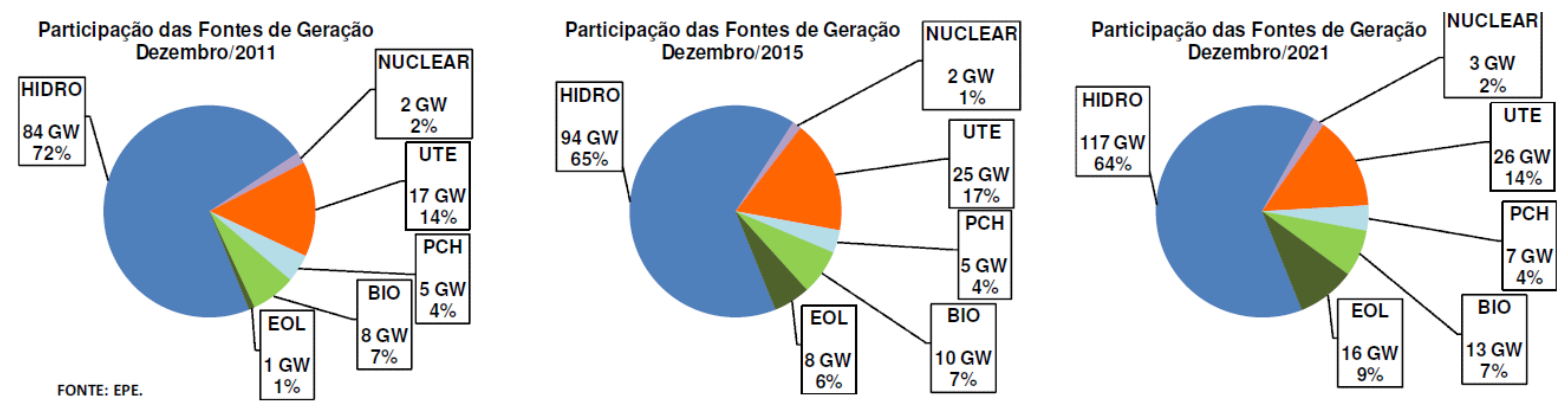

Figura 8 - Participação das fontes de geração de energia entre o ano 2011 e 2021 (fonte: EPE).

Tabela 4 - Relação de GW gerados e redução de emissões de $\mathrm{CO}_{2}$.

\begin{tabular}{|ccc|}
\hline Ano & GW & $\begin{array}{c}\text { Redução de emissão } \\
\text { (Tons de } \mathrm{CO}_{2} \text { por ano) }\end{array}$ \\
\hline 2021 & 16 & 13.700 .000 \\
2030 & 17 & 25.186 .891 \\
2040 & 19 & 59.626 .531 \\
2050 & 142 & 121.587 .500 \\
2060 & 144 & 123.300 .000 \\
\hline
\end{tabular}

em 2012 foram evitados 1,2 milhões de toneladas de $\mathrm{CO}_{2}$ evitadas por ano, em 2015 serão evitados 7,2 milhões de toneladas de $\mathrm{CO}_{2}$ e em 2021 13,7 milhões de toneladas de $\mathrm{CO}_{2}$. Colige-se que estes resultados são fruto da harmonização dos instrumentos legais e dos instrumentos políticos que se focalizam no crescimento do espaço para a energia eólica. Contudo, na tabela 4 mostra-se a relação entre o aumento de capacidade instalada de energia eólica e a diminuição de emissões de $\mathrm{CO}_{2}$ projetadas por décadas da seguinte maneira:

\subsubsection{Instrumentos regulatórios e jurídicos no cenário Sustentável}

Dentro da dimensão política encontramos o que como instrumento dele o aspecto legal, já que contribui a configurar o modelo institucional para que acompanhar as diferentes transformações que requer o setor energético para tornar-se mais sustentável e fazer efetiva essa redução das emissões de CO2 projetadas na tabela 4 . Tudo o qual encontra fundamento na normatividade vigente que deve ser analisada e aplicada de forma sistemática, considerando desde o fundamento constitucional, até as regulações particulares emitidas pelas Agencias reguladoras. Com o qual se vislumbra efetuar um planejamento econômico por parte do governo o que claramente tem 
fundamento constitucional.

Década 2020 - 2030: Um dos instrumentos jurídicos o encontramos nos processo de leilões nos quais participam as fontes renováveis, deles resultam contratos de comercialização de energia. Os contratos que resultam da participação dos agentes nos leilões de energia são de médio e longo prazo e devido a que estes contratos têm clausulas compromissórias os conflitos são resolvidos por meio de arbitragem, o que da muita agilidade ao processo de resolução de controvérsias que possam surgir entre as partes.

Os contratos de comercialização de energia no ambiente regulado por disponibilidade para a fonte eólica decorrem dos processos de leilões que são juridicamente licitações, com todo o processo contratual aprovado pela Agencia Nacional de Energia Elétrica ANEEL. Estes contratos permitem dar dinamismo ao mercado de energia elétrica e são basicamente contratos que obedecem à natureza jurídica de contratos de compra e venda de energia elétrica, com as particularidades próprias do setor elétrico.

Como resultado dos leilões também se consegue obter um preço competitivo o que permite que a energia eólica continue sendo considerada como uma importante fonte. Nos últimos contratos decorrentes do leilão de 2013 a duração será de 20 anos e começaram sua vigência a partir de 2015. Nesta década a prática dos leilões continuara aplicando-se em matéria de energia eólica.

Visando incentivar a oferta de energia eólica e abrir um espaço para tornar a matriz energética mais diversificada, consagrou-se a redução dos encargos de uso do sistema de transmissão e distribuição que aplica para as fontes alternativas. Iniciativa que foi consagrada na lei 10.762 de 2003 e posteriormente se regulo nas resoluções ANEEL No. 077 de 2004 e 271 de 2007.

Continuar-se-á aplicando a lei No. 11.488 de 2007 que contempla o Regime Especial de Incentivos para o Desenvolvimento da Infraestrutura - REIDI e no qual os projetos de infraestrutura relacionados com o setor energético se beneficiaram desta prerrogativa. 
Década de 2030 - 2040: Nesta década a normatividade permitira que continue a expansão de energia dos projetos de energia eólica por meio de leilões dos quais surgem contratos de longo prazo, conseguindo um crescimento de $9 \%$ da energia eólica na matriz energética. Os contratos a longo e meio prazo que se concretizam nos leilões vão contar com a suficiente segurança jurídica, já que contam com um fundamento jurídico e regulatório com bastante maturidade.

A legislação permitira que seja mais ágil os processo de obtenção de documentos tais como Documentos de Concepção do Projeto (DCP). Em decorrência do aumento da presença de energia eólica no SIN os encargos de serviços de sistema continuaram sendo reduzidos gradativamente já que diminuirá a necessidade de que o operador nacional do sistema ONS despache térmicas.

Nesta década é inserido com efetividade mediante a normatividade o incentivo de FIT, já que é o sistema que mais potencializa a inserção das energias renováveis, com fundamento nas experiências da Alemanha, Espanha e Dinamarca. Assim determinara-se um mercado especifico para as fontes de energia renovável obrigando as concessionárias a comprar energia limpa, com um preço que é determinado pelo governo. Igualmente, é assinado para energia eólica mediante a regulação seu próprio modelo de tarifas com estruturação do subsidio aplicável e o período que este será viável, promovendo com isso o equilíbrio econômico financeiro do investidor (FADIGAS; FARIA, 2011).

Continuam vigentes as políticas públicas sobre isenção de impostos sobre Circulação de Mercadorias e Serviços ICMS e Imposto sobre Produtos Industrializados IPI. E concretizar-se-á a política de liberdade para escolher a fonte de energia usada pelo consumidos final.

Década de 2040 - 2050: Continua tendo aplicação o modelo de leilões com contratos de comercialização de energia para o mercado regulado. Mas nesta década o sistema adquire maior maturidade, e os processos dos leilões para a fonte de energia eólica conta com uma programação mais rigorosa. Nesta década com base na normatividade e na política energética é possível determinar a quantidade de energia eólica que vai ser adquirida no mercado, o que da maior solidez ao mercado tanto para a 
oferta quanto para a demanda.

Nesta década já não se contara mais com o incentivo de redução nos encargos pelo uso do sistema de distribuição e do sistema de transmissão, já que o mercado se encontra mais consolidado. E ainda continuam aplicando-se o incentivo de FIT, para preservar o mercado especifico com o que conta a energia eólica.

Neste período encontra-se consolidada a política de liberdade tanto para escolher a fonte de energia como para escolher o provedor da mesma, decisão que é tomada pelo usuário final. E o pais alcança a nacionalização do $100 \%$ dos equipamentos para a geração de energia eólica.

Década de 2050 - 2060: Continuam sendo aplicados os contratos de comercialização de energia que decorrem dos leilões. E se aplicam dos incentivos como FIT e adicionalmente se incorpora mediante a legislação o incentivo de sistema de cotas para todas as fontes de energia renovável. Com ele o governo fixara a quantidade de energia renovável que deve ser produzida, levando em consideração que no inicio desta década o Brasil já terá atingido o seu potencial eólico. Com o qual se contribui para que o investidos tenha maior estabilidade econômica e financeira o que redunda em segurança jurídica para dar satisfação a suas obrigações contratuais decorrentes da negociação no mercado energético. O incentivo de sistema de cotas se conhece na literatura como Renewable Portafolio Standard (RPS) ou Renewable Energy Targets. Quando já se há fixado as metas de energia verde se regula o mercado para auferir ganhos na receita dos produtores e também se estabelece o procedimento de negociação dos certificados verdes (FADIGAS; FARIA, 2011).

Outro fator relevante é que continua sendo produzida a totalidade dos equipamentos para cobrir a demanda proveniente do mercado de energia eólica e ainda são isentos dos impostos sobre mercadorias. 


\section{INTEGRAÇÃO ENERGÉTICA REGIONAL, POLÍTICAS PÚBLICAS E SEUS EFEITOS NA ENERGIA EÓLICA}

\section{1 importância política da energia no cenário internacional}

A energia elétrica quando vislumbrada como um assunto de integração regional é relevante, na medida em que constitui um instrumento que potencializa o estabelecimento de relações de interdependência entre os estados. No contexto internacional a energia ocupa um lugar destacado, de acordo com Igor Fuser "o acesso à energia implica numa articulação entre produtores e consumidores, envolvendo conflito, negociação e consenso" (ENERGIA..., 2013). Esses mesmos elementos podem ser extrapolados às relações internacionais quanto o assunto de negociação é energia, devido à desigualdade na alocação e distribuição dos recursos energéticos.

Porém, a energia também viabiliza a oportunidade de ter negociações relevantes com outros países, devido as necessidades constantes dos países com intercâmbios de energia para complementar suas matrizes elétricas e ter segurança em seus sistemas. A soberania energética em geral é um fator de preocupação para os países, pois não querem comprometer sua independência elétrica e a dependência de outros países pode representar um custo político alto. O certo é que as integrações de energia elétrica constituem um tema de importância que se situa no centro das relações internacionais e se incluí na agenda política das integrações regionais (KLARE, 2008), sendo vislumbrada como elemento de poder geopolítico.

Evidencia-se a correlação direta entre energia e geopolítica como salienta ISBELL: "A energia influi no dinamismo da economia internacional, na estabilidade geopolítica mundial e em nosso futuro ambiental de escala planetária, senão também parece que a questão energética não voltará a um segundo plano estratégico pelo menos durante várias décadas".

Neste capítulo pretende-se elucidar a importância da energia elétrica e sua mais recente inovação, as energias renováveis nos processos de integração regional. Consideram-se os efeitos concretos que o referido processo terá para a energia eólica, já que o tema é um incentivo para que surjam alianças estratégicas que evidenciem 
a cooperação internacional por meio de relações internacionais bilaterais no âmbito das integrações regionais. Questões fundamentais como o planejamento energético, a segurança, pobreza energética e diversificação da matriz elétrica, requerem um tratamento conjunto pela sociedade internacional, conjuntamente a decisões específicas no âmbito nacional em atenção às particularidades de cada país e suas necessidades energéticas.

\subsubsection{Direito de integração e seus aportes à questão de energia}

Dotar as relações internacionais de valores como justiça, paz e respeito a autodeterminação dos povos é fundamental para manter a estabilidade na sociedade internacional, algo que sempre esteve presente nos pensamentos liberais representados por autores como Kant, Rousseau, entre outros. Mas, as mudanças de necessidades e as formas em que os países se relacionam sofrem alterações, as quais são acompanhadas por estratégias de geopolítica (MITRANY, 1994). Isso se encontra devidamente representado pelas teorias neorealistas que reconhecem as transformações e adaptam seu comportamento político a fim de abrir espaço para os atores determinantes no cenário internacional, o que não é atualmente uma exclusividade dos Estados.

Dos paradigmas das relações internacionais surgiu o neofuncionalismo para tentar explicar as motivações dos países em processos de integração e a pluralidade dos atores que influenciam as interações na sociedade internacional (NYE; KEOHANE, 1971). Nos processos de integração o tema da energia pode ser considerado em várias ocasiões, como um spilover, ou motor de integração no sentido neofuncionalista, mas geralmente tangível no caso das interligações físicas em linhas de transmissão ou no caso da represa de Itaipu. Mas devido a problemática das mudanças climáticas estar no centro do debate internacional, o tema das energias renováveis adquirem particular importância para o desenvolvimento das relações internacionais a partir de processos de cooperação.

Tradicionalmente as relações internacionais se configuram em torno da expectativa de poder, o que faz com que conflitos estejam sempre latentes, de modo que a ética e a política resultam inconciliáveis; esta linha de pensamento foi característica do realismo, representado por autores como Maquiavelo, Morguenthau e Kennan. Dife- 
rindo da anterior, e no âmbito do pensamento liberal, para esses autores nas relações internacionais existem elementos materiais determinados pelo interesse comum dos atores internacionais, não somente justificado pela ideia de poder e preponderância de um país sobre outro, mas sob o conceito de reciprocidade (AXELROD, 1986), para o qual se requer um plano de igualdade devido às assimetrias dentre os membros da sociedade internacional. Todavia tal pensamento se torna, na prática, complexo.

Assim, nas premissas do neofuncionalismo, as necessidades particulares de cada país são o ponto de partida para elucidar qual será o critério de seletividade para estabelecer alianças estratégicas com outros Estados e para entrar em blocos de integração. Tratando-se da energia elétrica os principais motivos são a preocupação com a continuidade do serviço, com a segurança e com a modicidade tarifária, tudo que pode levar um Estado a ser ou vulnerável ou forte na sociedade internacional.Recentemente o tema da geração de energia elétrica, segundo observado no decorrer deste trabalho, tem sofrido uma importante influência do tema de mudanças climáticas, o que justifica o tratamento internacional do tema, tanto pelo direito ambiental internacional, como pelos processos de integrações regionais.

"As alianças estratégicas se constroem sobre a base de uma relação alçada no diálogo, na consulta, no conserto e na cooperação. Neste processo, a confiança é um elemento chave, posto que, na medida em que as partes creem que seu sócio cumprirá com o pautado, reduz-se a incerteza sobre o curso de ações perante o futuro" (p. 51) (LORENZINI, 2011)

Parte-se do pressuposto de que as relações internacionais relacionadas com a cooperação para o desenvolvimento, especificamente a com caráter técnico, pode ser mais eficiente e eficaz quando direcionadas pelo interesse comum da energia renovável. De maneira a ser, inclusive, um parâmetro para potencializar a contribuição de um determinado país na sociedade internacional, como no caso da Alemanha que com sua tecnologia limpa possui espaço privilegiado no cenário internacional como referência em transição energética.

Pela perspectiva das relações internacionais, o neofuncionalismo permite explicar a necessidade do Estado em procurar soluções eficientes para suas necessidades nacionais no plano internacional (NYE; KEOHANE, 1971). No contexto de uma economia 
Tabela 5 - Estratégia europeia para energia e desenvolvimento sustentável.

\begin{tabular}{|ccccc|}
\hline Indicador & $\begin{array}{c}\text { Diretiva } \\
2001 / 77 / E C\end{array}$ & $\begin{array}{c}\text { Diretiva } \\
2009 / 28 / C E\end{array}$ & 2014 & $\begin{array}{c}\text { Proposta de } \\
\text { Regulamen- } \\
\text { tação 2017 }\end{array}$ \\
\hline $\begin{array}{c}\text { Energias } \\
\text { Renováveis }\end{array}$ & $21 \%$ & $20 \%$ & $27 \%$ & $30 \%$ \\
\hline $\begin{array}{c}\text { Eficiência } \\
\text { energética }\end{array}$ & $20 \%$ & $27-30 \%$ & $40 \%$ \\
\hline $\begin{array}{c}\text { Reducción de } \\
\text { emisiones de } \\
\text { gases efecto } \\
\text { invernadero }\end{array}$ & $20 \%$ & $40 \%$ & \\
\hline $\begin{array}{c}\text { Redução do } \\
\text { consumo } \\
\text { de energia }\end{array}$ & & & \\
\hline
\end{tabular}

Tabela 6 - Capacidade de interligação internacional dos países de Mercosul.

\begin{tabular}{|cc|}
\hline $\begin{array}{c}\text { Capacidade da } \\
\text { Interconexão } \\
\text { internacional }\end{array}$ & $\begin{array}{c}\text { Países que } \\
\text { participam }\end{array}$ \\
\hline $50 \mathrm{MW}$ & Argentina e Brasil \\
$70 \mathrm{MW}$ & Brasil e Uruguai \\
\hline
\end{tabular}

globalizada também existe a necessidade global de contar com energia sustentável e, para tanto, os Estados devem privilegiar a participação das fontes renováveis nas suas matrizes elétricas.

Independentemente do tipo de integração internacional objeto de análises, todas partem da necessidade da cooperação internacional perante expectativas de benefícios para os interesses dos países considerados individualmente (NYE; KEOHANE, 1971), tendo como premissa que o Estado isoladamente não consegue satisfazer as necessidades dos administrados. Por meio das integrações internacionais, consideradas como organização intergovernamental ou supranacional, não podem ser resolvidos todos os problemas contemporâneos dos Estados, porém uma resposta significativa para esses problemas pode advir de ações conjuntas e do trabalho cooperativo na sociedade internacional. 


\section{COMPARAÇÃO DOS MODELOS NORMATIVOS PARA ENERGIAS RENOVÁVEIS E SEUS EFEITOS JURÍDICOS PARA A ENERGIA EÓLICA}

\subsection{Particularidades na Espanha para a gestão de energias renováveis: as com- petências do Estado e das Comunidades Autônomas em matéria de energia elétrica e energias renováveis}

Segundo os princípios políticos e econômicos da ordenação econômica que foram estabelecidos na Constituição Espanhola, delineou-se um modelo de economia social de mercado que admite a intervenção do Estado na economia, mas ao mesmo tempo promove a liberdade da empresa. Neste contexto foram distribuídas as competências de tipo administrativo nos âmbitos nacionais e das Comunidades Autônomas, propendendo pela unidade nacional, mas atribuindo certo grau de autonomia às localidades para gerir seus próprios assuntos (ALVAREZ; GARRIDO; TUR, 2017). Esta distribuição de competências tem como pressuposto básico a harmonização entre as normatividades dos diferentes níveis nacionais e locais e com uma clareza quanto à margem das competências, de tal sorte que as normas não sejam incompatíveis e não gerem discrepâncias no momento de eleger qual é a normativa aplicável.

Não obstante quando o tema é a energia, por ter um impacto nacional ao ser um setor estratégico da economia, a normatividade deve guardar maior observância à integralidade de tratamento e uniformidade na sua aplicação (NAVARRO, 2013). Independentemente de qual comunidade autônoma gera mais eletricidade, o sistema elétrico espanhol é considerado em sua totalidade e as soluções aos problemas que apresenta devem ser abordados de maneira prevalentemente estatal e posteriormente se analisam as particularidades de cada comunidade. Porem a normatividade das comunidades autônomas devém acolher o que determina o âmbito legislativo e regulatório do Estado.

No que concerne ao planejamento da energia a responsabilidade é exclusiva do Estado, em termos gerais o planejamento da atividade econômica corresponde ao Estado, segundo o estabelecem os artigos 148 e 149 da Constituição Espanhola. Especificamente a energia constitui um fator estratégico na economia e uma ferramenta fundamental para a satisfação dos fins últimos do Estado. Contudo, as comunidades 
autônomas têm a capacidade jurídica para fomentar as energias renováveis, mas o planejamento centralizado pertence ao Estado.

O anterior se encontra em consonância com o estabelecido na doutrina do Tribunal Constitucional Espanhol (segundo a seguinte jurisprudência: SSTC 12/1984, de 2 de fevereiro, 24/1985, de 21 de fevereiro, 119/1986, de 20 de outubro, 133/1990, de 19 de julho, 67/1992, de 30 de abril, 74/1992, de 15 de maio, 108/1996, de 13 de junho, 197/1996, de 28 de novembro, 15/1997, de 30 de janeiro, 13/1998, de 22 de janeiro, 25/2002, de 11 de fevereiro, 175/2003, de 30 de setembro, 165/2003, de 29 de setembro, 109/2004, de 30 de junho, e 14/2004, de 12 de fevereiro).

Frente ao tema das energias renováveis por ser um assunto de utilidade pública o Estado conserva a competência geral e abrangente no que tange ao planejamento e a regulação de todas as fases da implementação e execução dos projetos, embora as Comunidades Autônomas também tenham competências da atividade de planejamento, mas acordes com as políticas gerais do Estado. O setor elétrico espanhol apresenta a particularidade de compartilhar algumas competências em matéria de energia com as comunidades autônomas e além de tudo tem que guardar observância às diretivas da União Europeia. Por esta tripla fonte de normas, diretivas e regulamentação, a interpretação sistemática da normatividade do setor elétrico espanhol torna-se demasiado complexa já que se tem que atender as especificidades dos diferentes níveis de regulação.

Não se pode perder de vista que a regulação do setor elétrico esta diretamente vinculada com a ordem econômica do país e a distribuição de competências para o setor elétrico que obedece a critérios de política econômica. Certamente o setor elétrico espanhol teve sua liberalização com a Lei No. 54 de 27 de novembro de 1997, lei que foi posteriormente modificada pela Lei No. 17 de 4 de Julho de 2007, para finalmente ser adaptada à normatividade da UE Diretiva 2003/54/CE. A importância prática desta evolução normativa está dada pela consolidação dos fatores determinantes para garantir a inserção das fontes renováveis, entre elas a eólica, no sistema elétrico espanhol. 


\subsubsection{Instituições jurídicas para exercer a atividade de geração eólica na Espa- nha}

As instalações de energia renovável devem se acolher a um regime especial quando no superem os $50 \mathrm{MW}$, sendo necessária uma autorização administrativa previa (artigo 21 da LSE), que obedece a uma competência regrada das comunidades autônomas. O anterior guarda observância dos princípios jurídicos de objetividade, transparência e não discriminação, o que dá ao processo certa segurança jurídica no que tange aos procedimentos para aceder às autorizações. Mas deve advertir-se que existe uma exceção para as instalações eólicas que se encontrem em várias comunidades autônomas e as que se encontrem em superfícies offshore, já que estas fazem sua solicitação de autorização na direção geral de política energética e minas do Ministério da indústria, turismo e Comercio, tal como previsto no real decreto 661 de 2007, já que a competência é exclusiva do Estado, além de ser um procedimento que prevê a concorrência para a assinação de adjudicação de qualquer projeto eólico offshore.

No que tange as autorizações das instalações elétricas de geração eólica fica claro que, dependendo do porte do projeto, a competência para autorizar vai ser a do Estado ou da Comunidade autônoma tal como decorre do seguinte texto normativo:

O Art. 2.a) dispõe que é competência do Estado autorizar as instalações elétricas de geração de potência elétrica instalada superior a 50 MW. No artigo 3.3.c) estabelece a competência das comunidades autônomas para autorizar as instalações elétricas não contempladas no ponto a) do artigo 2, assim como exercer as competências de inspeção e sanção que afetem a tais instalações. (Tradução própria).

Esta normatividade sugere que existe concorrência de competência em matéria de instalação de geração de energia, o que fica sujeito à capacidade de geração de cada empreendimento. Não obstante, é claro que quando se trata de energias renováveis, as comunidades autônomas só tem competência para seu fomento e para as autorizações, mas não para proferir regulação específica, conforme se deriva da Lei do Setor Elétrico Espanhol No. 54 de 1997 Art. 3 em diante (LSE). 
Certamente com a proliferação de solicitações de autorização para instalações eólicas, fruto da política de fomento às energias renováveis que começou em 2004, as comunidades autônomas tem modificado suas normas sobre planejamento e gestão dos seus territórios em função desta nova variável. A competência autonômica é exercida levando em consideração a perspectiva ambiental e urbanística, orientando as ações à determinação da sua capacidade eólica, dos territórios viáveis para esta fonte de energia e dos que são excluídos, e algumas comunidades autônomas optam por detalhar os requerimentos para a autorização das instalações e outras em que omitem esta informação.

\subsubsection{Regulação para energias renováveis na Espanha}

A regulação para energias renováveis está sendo desenvolvida considerando a necessidade que tem o país de incrementar a cota de participação no mix elétrico, sendo a energia eólica a tecnologia que mais incremento teve no mercado espanhol. Fruto disso pode-se afirmar que a proliferação das instalações eólicas foi consequência da legislação que teve bastante eficiência para incentivar aos investidores a esta forma de geração de energia elétrica.

Os incentivos consistiram bascamente na aplicação de FIT e tarifa Premium como modelos econômicos mais idôneos para impulsionar a energia eólica e permitir sua inserção. Com isso basicamente se tem investidores com fundamento suficiente para interpretar que a normatividade espanhola oferecia segurança jurídica para os investimentos na fonte eólica. Certamente essa segurança para investir era igualmente cimentada nas respostas do mercado, embora no inicio houvesse ausência dos fundamentos legais para as energias renováveis, conforme refletido nos documentos de planejamento do setor elétrico.

O sistema de tarifas para a energia eólica contava com primas estáveis que garantiam o retorno do investimento. A vigência dos contratos de geração poderia ser de 10 a 20 anos com a vantagem de que toda a energia que se produz será comprada e alem disso terá duas opções para que se fixe o preço, uma via legal e outra via mercado. Com estes parâmetros foi estabelecido o regime especial de produção de eletricidade, que considera as vantagens da inserção das energias renováveis para 
justificar os subsídios de longo prazo para os empreendimentos.

\subsubsection{Problemática atual da normatividade espanhola referente a energias re- nováveis e o caso especifico da energia eólica}

Espanha apresenta atualmente uma problemática em torno à regulação para as energias renováveis devido a sua abrupta mudança na normatividade neste tema. Em primeira instância, a legitimidade que tem o Estado para dirigir os desígnios dos países depende em grande medida da observância à lei e da confiabilidade que o princípio de legalidade dá a todos os procedimentos da vida política, econômica e social. Este princípio de legalidade norteia o desenvolvimento do Estado e constitui uma garantia para estabelecer legitimas expectativas nas suas relações jurídicas com o Estado, quando este se configura como estado de direito (SHIRATO, 2012).

Assim, essa segurança jurídica que se tem no ordenamento jurídico no caso da normatividade de energias renováveis pode ver-se alterada e justamente é a constatação que se efetuara a continuação. Em primeira instância, se evidencia que a energia como uma das atividades que apresentam uma presença mais forte do Estado deve gozar também de certa estabilidade a fim de que esta característica se evidencie nas relações jurídico- econômicas que se originem no setor elétrico.

Resulta preocupante os efeitos que possa ter na regulação e no mercado espanhol o caso EISER INFRAESTRUCTURE LIMITED versus Espanha, onde no processo de arbitragem internacional, se condena a Espanha no Laudo Arbitral No. ARB/13/36 de 4 de maio de 2017 a pagar de $\$ 128$ milhões de Euros mais os juros. Basicamente o falho analisa as expectativas legitimas dos investidores estrangeiros que fizeram seus investimentos de acordo ao Plano de energias renováveis que tinha um regime remuneratório.

Posteriormente, com o real Decreto-Lei 9/2013 se teve uma mudança transcendental no regime de remuneração sobre o qual foi projetado o investimento financeiro da empresa EISER INFRAESTRUCTURE LIMITED e que certamente prejudicou drasticamente o equilíbrio econômico financeiro.

Pelo tanto, os principais problemas estão relacionados com os aspectos regulatórios como o financiamento e sustentabilidade, se bem é certo que a implementação 
das energias renováveis é uma meta que deve ser alcançada e apoiada pelo governo espanhol isso não implica desconhecer as dificuldades para conseguir essa meta. Justamente um desses inconvenientes é o problema das primas para energia renovável por que mesmo que seja um assunto de política energética nacional, são os consumidores finais os que terminam pagando sua implementação.

As empresas prestadoras do serviço de eletricidade agora tem que assumir uma conduta muito mais proativa com relação ao meio ambiente e ao urbanismo. Tradicionalmente, estas empresas no desenvolvimento da sua atividade tem que guardar observância aos objetivos de modicidade, universalidade e mais recentemente eficiência energética, mas agora perante um novo cenário regulatório que visa cumprir objetivos perante a mudança climática que trás consigo outros indicadores de qualidade que, com certeza, implicam mudanças no sistema de gestão e nas finanças.

No que tange ao financiamento encontram-se alguns inconvenientes na Lei 24/2013, de 26 de dezembro, do setor elétrico espanhol, Especificamente em seu título III estabelece a Sustentabilidade econômica e financeira do sistema elétrico. O qual contém o regime de retribuição especifico com um instrumento de competição.

Os mecanismos para sair dos períodos de crise econômica pelo desequilíbrio entre os ingressos e custos do sistema, encontram-se previstos no artigo 19 Inclui compensações orçamentárias com uma porcentagem do orçamento geral do Estado.

A maior preocupação é pelo equilíbrio financeiro do sistema elétrico e para isso são constantes as revisões e os ajustes, o qual deve ter uma externalidade positiva com relação aos preços finais de energia todo o qual conforma um excelente indicador econômico para o sistema. Igualmente tem que ser considerado que as oscilações nos preços da energia não obedecem necessariamente ao comportamento de equilibro entre ingressos e custo e adicionalmente, tem que ter em consideração que a energia do mercado atacadista não se calcula dentro da liquidação do preço final. (isso pode gerar uma alteração considerável no preço final que não é possível prever).

O sistema elétrico espanhol esta preocupado com o fato de ter (ou com a necessidade de se ter ) um controle sobre a sustentabilidade econômica e social do setor elétrico. No que se refere à sustentabilidade social que vislumbra a proteção dos consumidores vulneráveis o paliativo foi o estabelecimento de bônus social. 
Preços voluntários para o pequeno consumidor (é uma novidade da normatividade, com os preços regulados) o importante de esta decisão regulatória é permitir conservar uma certa estabilidade nos preços de energia final e afastar os riscos de depender do mercado atacadista de energia, onde os preços podem apresentar maiores variações. Esta medida foi adotada por meio do real Decreto 216/214, esta medida encerra um risco de sazonalidade previsto no artigo 6 que estabelece o seguinte:

Artículo 6.2.a) del Real Decreto 216/2014 "el coste de producción de energía eléctrica, que se determinará con base en el precio horario de los mercados diario e intradiario durante el período al que corresponda la facturación, los costes de los servicios de ajuste del sistema y, en su caso, otros costes asociados al suministro conforme se establece en el presente real decreto". (Tradução própria).

A remuneração da energia renovável é considerada para estabelecer a base remuneratória a vida útil da instalação e se bem o aumento da participação das renováveis é iminente o processo de transição energética deve ser feito sem prejudicar ou gerar uma alteração dos preços da energia para o consumidor final, especialmente por que a Espanha tem uma das tarifas de energia mais onerosas da Europa.

Os critérios do leilão são feitos considerando a competitividade, onde cada empresa participante tinha que informar sua capacidade instalada e os valores dos investimentos requeridos para a geração. Uma vez abertas as ofertas, determinava-se qual tinha o menor custo ou menor incentivo para geração.

O incremento da participação de energia eólica na Espanha tem sido considerável em função do desenvolvimento da normatividade e das políticas públicas o que evidencia-se na prolifereção de parque eólicas que abarcam cuasi todo o territorio segundo se evidencia no mapa 9

\subsubsection{Alemanha e sua regulação para energia renováveis}

Alemanha percebe a transição energética como uma oportunidade para sua economia que vincula a todas as esferas da sociedade e entende que este é o pilar fundamental para alcançar o desenvolvimento sustentável. É assim como empreende o 


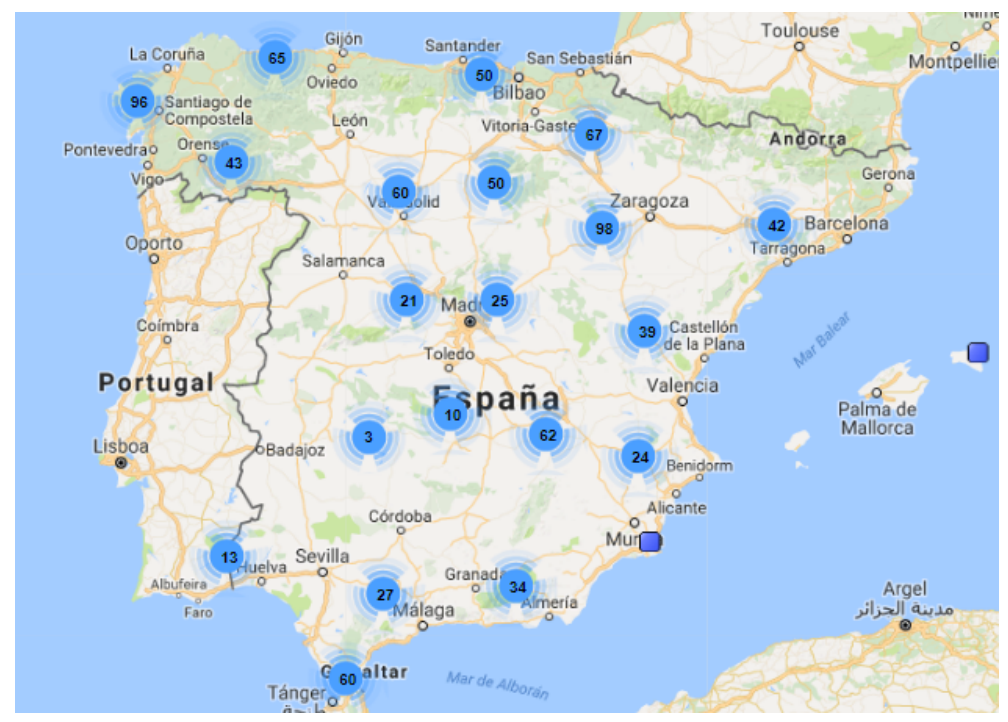

Figura 9 - Mapa eólico da Espanha (fonte: WWE 2016).

processo, há uma economia que cumpre os conteúdos programáticos do desenvolvimento sustentável o qual tem fundamento constitucional.

$\mathrm{Na}$ lei fundamental alemã foi consagrado o direito ao meio ambiente por meio de uma reforma constitucional, e adicionalmente tem rango direito fundamental, no artigo 20a, no qual se específica que o cuidado do ambiente faz parte da responsabilidade que se tem com as gerações futuras.

Article 20a Protection of the natural foundations of life and animals Mindful also of its responsibility toward future generations, the state shall protect the natural foundations of life and animals by legislation and, in accordance with law and justice, by executive and judicial action, all within the framework of the constitutional order.

Igualmente a normatividade dos entes territoriais ou Lander, aprofunda mais o direito ao ambiente. Alemanha iniciou seu caminho para a transição energética desde a década dos 90, entendido como ponto de partida para um novo modelo de crescimento econômico. Gerando simultaneamente desenvolvimento econômico, novos negócios, fontes de emprego e sendo ambientalmente adequado. Essa transição energética não foi um processo isolado da comunidade, muito pelo contrario a sociedade alemã, suas comunidades e os diversos atores do setor público e privado tem sido partícipes e protagonistas em todas as fases do desenvolvimento da energia limpa, tornando o processo democrático e participativo. 
Esta abordagem de transição energética tem como singularidade a inclusão de todos os setores da sociedade, permitindo contar com um modelo integral para implementar as mudanças gradativamente. É dizer mudanças que respondam às necessidades das comunidades, das empresas de pequena, media e grande porte e finalmente aos compromissos do país no cenário internacional, sem que seja de forma abrupta, senão conforme as respostas do mercado, da sociedade e do próprio setor elétrico.

A configuração da normatividade e do arcabouço regulatório para avançar no caminho da transição energética, tem sido ambicioso desde o inicio do processo e pelo apoio da sua política climática e energética. Mas claramente o consumo de energia elétrica também vem aumentando e cientes de este fato, já em 2007 o Governo Federal da Alemanha adotou a decisão de Meseberg como um programa que integra os aspectos de mudança climática e energia, e que contempla objetivos ainda mais rigorosos do que os estabelecidos na Diretiva Europeia 2009/28/CE.

Outro dos aspectos que merece ser destacado é que a tecnologia alemã desempenha um papel importante neste processo de transição energética especialmente quando se avança no quesito da cooperação internacional.

A transição energética no que respeita à fonte eólica teve a participação de vários elementos para seu desenvolvimento e sucesso, tais como fatores naturais, elementos técnicos, atores sociais e institucionais e desenvolvimento de metas estratégicas. Este momento conjuntural foi estruturado sobre a base dos princípios da segurança do sistema e da modicidade tarifaria, aspectos fundamentais para preservar a economia e a competitividade tanto internamente como na sociedade internacional.

\subsubsection{O planejamento energético alemão}

A política energética alemã tem três pilares que são segurança no fornecimento, rentabilidade e proteção do ambiente. As ações políticas e legislativas em matéria de energias renováveis são programáticas e planejadas através de uma estratégia que se inclina pela proporcionalidade entre os pilares da política energética. Uma das metas relevantes para o setor energético alemão é o desligamento paulatino das suas centrais nucleares, mas para fazer isto sem pôr em risco a segurança no fornecimento 
do serviço público de energia é preciso diversificar as fontes e claramente a ênfases dessa diversificação tem como eixo central as energias renováveis, sendo a energia eólica a que apresenta maior desenvolvimento.

A sua proposta para responder às necessidades da transição energética vislumbram um incremento das energias renováveis ao consumo final bruto de energia de $18 \%$ até $2020,30 \%$ até 2030 e de $60 \%$ até 2050 . No que tange à oferta das energias renováveis a expectativa na geração é o incremento de pelo menos $35 \%$ até 2020 , um $50 \%$ até 2030 , um $65 \%$ até 2040 e para o ano 2050 a previsão de participação é de $60 \%$. No tema de energias renováveis a Alemanha sempre tem sido pioneira tanto no arcabouço regulatório como no aspecto tecnológico, seus objetivos chegando inclusive a superar os objetivos comunitários.

Também o planejamento visa responder aos compromissos comunitários de geração limpa, eficiência energética e diminuição do consumo que a UE tem estabelecido em suas diretivas, onde se estabeleceram os objetivos anteriormente mencionados e que atualmente são de cumprimento obrigatório. Esta matéria representa uma responsabilidade para a governança do setor elétrico alemão, especialmente quando se considera que tem efeitos no mercado que podem comprometer o equilíbrio econômico do país, e nesta medida devem ser ponderados e monitorados os resultados após a implementação da sua normatividade.

O planejamento do setor elétrico alemão inclui a legislação para energias renováveis, em varias fases para responder aos critérios de mercado e para tornar competitivas estas tecnologias de geração limpa. Todo o desenvolvimento normativo para as energias eólicas é desenvolvido conforme a decisão Meseberg, dos anos 90 que promove pela primeira vez uma integração entre clima, ambiente e energia.

Essas modificações são levadas a cabo simultaneamente na UE e por isso também se deve considerar no planejamento os aspectos da cooperação regional que se incrementa em matéria de energia elétrica. Justamente este é um dos pilares do direito da integração, entender as assimetrias econômicas, sociais e políticas e contribuir conjuntamente para sua diminuição. Certamente a Alemanha, em termos de desenvolvimento tecnológico, leva a batuta dentro da UE e justamente por isso é considerado que devido a essa circunstância sua cooperação técnica perante a sociedade 
internacional resulta acentuada.

Como a ideia da transição energética é permear todas as atividades que envolvem o ciclo produtivo de eletricidade, o planejamento também inclui metas de desenvolvimento para transmissão e distribuição de energia. A transmissão teve uma modificação em seu marco normativo em 2015, vislumbrando a incorporação das tecnologias limpas e propendendo pela sua expansão para os lugares que requerem novas conexões.

Igualmente a transição também inclui objetivos em eficiência energética, com a aplicação do plano da ação da UE. (Diretiva), uma estratégia para os prédios e outra para o setor de transporte. Os aspectos mencionados fazem parte do processo de planejamento para a transição e abrangem o programa de acompanhamento do cumprimento dos objetivos e das estratégias para o setor elétrico, para com isso reformulálos se for preciso. Especialmente se são detectados aspectos que mereçam um tratamento diferenciado dentro dos cenários projetados pelo grupo de especialistas de acompanhamento do processo.

Foram criadas cinco plataformas de transição energética com a finalidade de que os atores envolvidos participem ativamente com base em informação verídica do setor elétrico (ver figura 10). Assim o setor privado, os pesquisadores, o setor político, a sociedade e o governo, constantemente intercambiam informações e estabelecem ações cooperativas em prol da transição energética. A intervenção destes diversos atores claramente envolvidos direita ou indiretamente na transição é legitimada justamente com a intervenção deste diversos atores que permitem chegar a acordos cimentados na participação democrática.

O mais interessante é o planejamento para o incremento de energias renováveis que obedece a guias específicas que indicam em que medida se requer ou não desenvolvimento para estas fontes. Tendo uma participação controlada das fontes renováveis, o que por sua vez permite a harmonização com o sistema elétrico. A diferença de Espanha evita um crescimento desmesurado e ineficiente destas fontes, que podem gerar prejuízos financeiros para os investidores.

Isso significa que a transição energética encontra-se dotada de todo um cenário de racionalidade segundo o comportamento do mercado, considerando custos de 


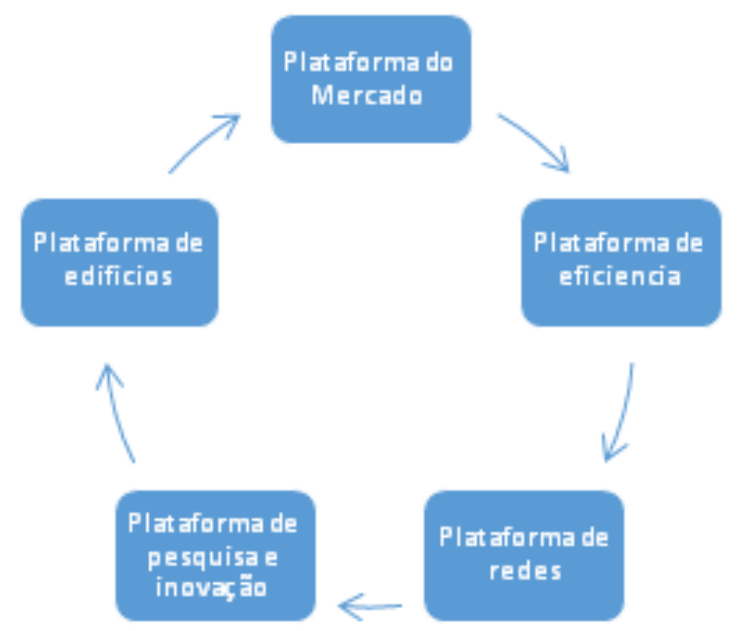

Figura 10 - Plataformas da transição energética na Alemanha (fonte: BMWi)

transação para a seleção dos incentivos regulatórios e das alternativas para considerar os novos modelos negociais (WILLIAMSON, 1996). Conforme as necessidades vão surgindo, o setor elétrico tem que ir incorporando essas novas variáveis, que no caso em estudo são respostas à mudança climática e incorporação de tecnologias limpas, o que também requer uma governança adequada que inclua as premissas do desenvolvimento sustentável.

Das opções jurídicas que permita um determinado modelo regulatório vai depender a evolução do mercado para as energias renováveis, o que também requer a coerência nas escolhas de incentivos e a segurança jurídica que aporte o planejamento e a gestão do setor.

Mesmo que o planejamento seja programático e que os objetivos do mercado estejam estabelecidos, o certo é que as modificações que acontecem na gestão do setor elétrico, no planejamento alemão se contemplam em um sistema de flexibilidade que informa a regulamentação de acordo com os acontecimentos do mercado.

\subsubsection{Legislação de energia renovável em Alemanha e seu efeito para a fonte eólica}

A primeira iniciativa legislativa que teve o intuito de incentivar a participação das energias renováveis foi a lei "Stromeinspeisungsgesetz - StromEinspG" ou mais conhecida como a lei sobre "alimentação da rede pública de eletricidade procedente de 
energias renováveis", de 7 de dezembro de 1990 que entrou em vigência em primeiro de janeiro de 1991 e implementou como incentivo para estas fontes de energia o modelo de FIT. Desta previsão legal derivam uma serie de direitos subjetivos para os projetos de energia renovável, que uma vez que cumprissem os requisitos para se constituir como geradores de energia renovável, automaticamente adquiriam o direito de compra da sua energia, por parte dos operadores das redes.

Esta lei promoveu a inserção da energia proveniente de fontes renováveis à redes de transmissão e distribuição e alem de esta medida, impôs a obrigação às empresas fornecedoras de eletricidade de compra toda a energia gerada a partir de fontes renováveis; nesse momento as fonte de energia que receberam esse benefício foram eólica, fotovoltaica, hidráulica e biomassa. Certamente para garantir a eficiência desta disposição o princípio de livre acesso às redes também se encontrava estabelecido, mas foi especificamente detalhado como acesso prioritário às redes, o que reforça a segurança jurídica do nomeado princípio.

A lei que continuou com a promoção e respaldo às energias renováveis chegou 10 anos depois da primeira lei e deu exclusividade de tratamento para energias renováveis é conhecida como a Lei de Energias Renováveis EEG, promulgada em 29 de março de 2000.

A lei de energias renováveis (Gesetz für den Vorrang Erneuerbarer Energien ou Erneuerbare-Energien-Gesetz) de 29 de março de 2000 e a lei combinada de calor e eletricidade (Kraft-Wärme-Kopplungsgesetz) de 12 de maio de 2000, no artigo terceiro da primeira lei reforça o princípio de livre acesso ás redes de distribuição e de transmissão dos empreendimentos que provenham das fontes renováveis. Isso constitui um importante fator de segurança para os novos empreendimentos e certamente contribui para o incremento da energia eólica.

A lei EEG, tem experimentado uma série de modificações que surgem como resposta às necessidades do setor, à sociedade e ao mercado, no processo de transição energética. Em decorrência a lei EEG sofreu sua primeira emenda em 2004, que posteriormente em 2009 entrou em vigência. Depois foi reformada em 2012 e sua última reforma é de 2016. Entre os períodos de transição legislativa da EEG antes nomeados têm existido confusões em quanto à aplicação da norma, até porque algumas vezes 
tem existido vigência simultânea das normas aplicáveis.

As modificações normativas tinham o intuito de aperfeiçoar o sistema de remuneração, o qual foi diferenciado por tipo de energia renovável. Como esta é uma energia social, também foi modificado no sentido de repartição das vantagens da remuneração e sua ótima redistribuição entre as localidades e os consumidores. Uma nova fase de responsabilidade onde tanto os geradores de energia renovável quanto os operadores das redes tem uma responsabilidade conjunta sobre as conexões, seu uso, operação e manutenção.

Posteriormente outra lei de energias renováveis entrou em vigência no primeiro de agosto de 2014, vislumbrando um desempenho melhor no incremento da participação das energias renováveis. Esta reforma para energias renováveis tem seu foco em duas tecnologias, que são a eólica e a solar. A seleção destas fontes obedece a critérios técnicos e econômicos, visando uma maior eficiência nos preços e nos custos de transação. A modificação legislativa teve como propósito promover mudanças no mercado, de tal forma que as energias renováveis não precisassem mais dos incentivos como as primas e ganhassem competitividade por se mesmas. Os direitos subjetivos que nasceram a partir dos incentivos regulatórios e que adquiriam os geradores que se constituíram como tais, representam uma obrigação para os distribuidores de energia que têm a obrigação de comprar lha. Esta carga econômica e jurídica que é imposta aos distribuidores finalmente é repassada aos usuários finais, que acabam pagando tarifas mais altas. A estruturação da remuneração com fundamento em um sistema de custos artificiais passa a ser uma carga onerosa, que é somada à tarifa final.

O aspecto mais relevante para ser considerado é que a atividade normativa e regulatória em torno da energia eólica encontra-se em permanente transformação, nunca antes mudanças na legislação tinham acontecido tão rápido. Por este motivo, dentro da projeção financeira dos investidores também deve ser considerado o grande risco regulatório como um fator determinante ao momento de celebrar negócios jurídicos.

O certo é que mesmo com uma normatividade que sofre constantes modificações, pelo menos um instrumento jurídico deve permanecer fiável para garantir a segurança jurídica. Certamente esse instrumento jurídico é o contrato, no caso das instalações 
eólicas na Alemanha que foram construídas durante a vigência da primeira lei de energias renováveis (Erneuerbare Energien Gesetz 2009 - EEG) e que, por conseguinte assinaram contratos de concessão e seguindo o princípio de que o contrato é lei para as partes, em torno deste instrumento jurídico se estrutura a confiança no sistema de incentivos para a fonte eólica e para as outras fontes que tenham sua participação no mercado garantia via contrato.

Para a materialização do programa de incentivos encontrava-se previsto na norma que os contratos tivessem duração de 20 anos, com uma compensação econômica que permitisse retribuir às renováveis com preços de acordo com os preços do mercado competitivo. Esse estímulo ou fomento para as energias renováveis teve um efeito positivo para o incremento da sua participação na matriz elétrica da Alemanha, principalmente na fonte eólica que incrementou consideravelmente sua participação por cima das outras fontes renováveis.

Claramente estes contratos têm em sua natureza subsídios, razão pela qual, devem responder à expectativa de levar o mercado da energia eólica a certa maturidade para ganhar espaço no mercado de energia. Uma vez alcançada essa meta da competitividade o sistema deveria responder a diferentes dinâmicas próprias do mercado e justamente a esses pressupostos deveria adaptar-se o ordenamento jurídico.

Juridicamente o nível de estabilidade dos contratos outorgados aos geradores de energias renováveis é alto quando comparado com o risco regulatório espanhol. Isso devido à intromissão ou efeito direito que teve o Real Decreto sob os contratos, tal como foi exposto anteriormente, embora que ainda não possa ser descartado por completo para os investidores a sombra da dúvida perante o sistema regulatório para a fonte eólica e para as outras renováveis em geral.

Não há sombra de dúvida para os investidores que as fontes eólicas e outras renováveis tem privilégios em relação a outras fontes. A estabilidade dos contratos de vinte anos com uma remuneração preestabelecida que não corresponde aos custos verdadeiros, foi um sistema de preços artificiais criado para permitir remunerar adequadamente os investimentos. Segundo (??), na Alemanha não deixa de estar presente o fenômeno de insegurança jurídica; não é tão extremo como no caso da Espanha, que certamente chega a se tornar um risco regulatório considerável, mas ainda assim 
os investidores apresentam dificuldades para lidar com as novidades regulatórias. $\mathrm{O}$ aspecto mais relevante em matéria de segurança jurídica do sistema alemão é que os contratos que se encontram vigentes não sofrem alterações, porque claramente aplica-se o princípio básico de não-retroatividade da lei.

Modificada posteriormente em 1998 pelo artigo 3, numeral 2, da Gesetz zur Neuregelung des Energiewirtschaftsrechts, de 24 de abril de 1998 (Lei sobre a nova regulação do Direito da economia energética, BGBI. 1998 I, p. 730.

No artigo 2 da precitada lei inicialmente se estabelece a obrigação para as empresas fornecedoras de energia elétrica de compra da energia gerada a partir de fontes hidráulica, eólica e solar, mas esta obrigação de compra tinha um preço mínimo da transação superior ao valor econômico, ou seja ao valor do mercado. Sem duvida esta obrigação de compra de energia renovável é uma carga financeira para as empresas de eletricidade para comprar energia proveniente de fontes renováveis, e se associa diretamente com áreas de concessão de fornecimento.

\subsubsection{Nova Abordagem Legislativa para Eólica}

Em 2017 começou uma nova fase para o desenvolvimento da fonte eólica com a entrada em vigência do sistema de leilão para os projetos diferenciando a eólica terrestre da marítima. A finalidade de esta normatividade é garantir a eficiência do processo de transição energética, mas harmonizando aspectos econômicos e a inserção ao mercado da fonte eólica de tal maneira que obtenha sua maturidade e independência no mercado elétrico.

Para alguns autores como PIERLOW, o novo sistema de licitação para os projetos eólicos vai ser efetuado com estrito seguimento do que estabelece o planejamento. É dizer que para efeitos de expansão da oferta eólica é fundamental acompanhar o processo de planejamento, mas não no sentido tradicional, no qual este vem sendo somente indicativo, senão em um sentido mais moderno e de alguma maneira mais exigente, já que certamente é obrigatório, dentro do que estão chamando os alemães como corredores de expansão. Pelo tanto este planejamento vinculante, também se encontra mais associado ao processo de eficiência dos custos para evitar desproporções econômicas que geram custos desnecessários para os investidores e para a 
sociedade em termos gerais, os quais se vinculam às ineficiências via tarifas.

Os objetivos máximos são os seguintes: para energia eólica terrestre a ampliação está prevista de 2.800MW entre 2017 e 2019 e de 2.900 desde o 2020, enquanto à eólica offshore a ampliação prevê 6.500 MW até 2020 e 15.000 MW até 2030.

Neste cenário é conveniente avaliar a pertinência da medida como meio para concretizar os fins da política energética, com um impacto específico na energia eólica. O fato é que os primeiros resultados indicam certamente uma desaceleração do processo para esta fonte.

Da lei EEG surgiram uma serie de instrumentos jurídicos para viabilizar a transição energética. Estes, contudo, apresentam uma singularidade de ser gestados desde o setor público, aplicando o direto administrativo, mas quando se materializam, os instrumentos jurídicos que the dão viabilidade pertencem ao direito privado. Certamente as metas de energia eólica são estabelecidas como planejamento energético, contribuem com a satisfação dos fins essenciais do Estado em quanto desenvolvimento sustentável, mas é a resposta da sociedade e do mercado, com a celebração de negócios jurídicos.

A ênfase está na proteção da confiança do setor privado no setor elétrico, que propende pela conexão às redes de forma prioritária, e pela remuneração das tarifas. Tal como o sinalizam WAERNER e FEDERWICH, a lei estabelece a obrigação contratual per ser de compra da energia e das obrigações que se derivam da lei EEG. Mas nos negócios jurídicos originados a partir da EGG a autonomia da vontade não tem muita possibilidade de desenvolver obrigações além das estipuladas via legal, já que tanto o conteúdo das obrigações quanto o preço da energia se encontram preestabelecidos.

A entrada em vigência das concorrências públicas para a comercialização de energia renovável o que pode trazer como resultado é que os produtores de menor porte se vejam ameaçados para se manter no mercado. Paralelo a isso, outro aspecto que merece ser considerado com relação a esta alteração legislativa é o fato de ter incidência direta nos custos de transação associados a esta nova carga financeira, podiam ser incluídos na contabilidade tanto dentro da rubrica de transporte pelo conceito de distribuição ou transmissão.

O direito ao pagamento para a central eólica que está inserido no sistema surge 
quando a instalação satisfaz os requerimentos da EEG; a remuneração tem relação direta com o porte do empreendimento eólico, diminuindo o valor com o aumento da capacidade instalada. Isso significa que quanto mais se avança na quota de participação de geração proporcionalmente vai decrescendo a retribuição econômica.

$\mathrm{Na}$ medida em que são efetuadas as modificações normativas em consideração aos avanços tecnológicos e ao planejamento, a remuneração com preços artificiais vai sendo alterada, no sentido que cada vez mais se responde em termos de eficiência. Sob esta premissa pode ser inferido que tanto os primeiros incentivos para a fonte eólica que estabeleciam uma remuneração básica, quanto o sistema de primas ou bônus vem diminuindo progressivamente, tendo como referência o ano em que começa a prestar o serviço correspondente ao empreendimento eólico.

Segundo o estipulado no artigo 20 numeral 2 da EEG a diminuição da retribuição para eólica pode oscilar em torno ao $1 \%$ para a terrestre e até $5 \%$ para a eólica offshore. No que respeita ao pagamento para a energia eólica é contemplada uma diferença entre a tecnologia terrestre e a marítima, de acordo com os artigos 29 a 31 da EEG.

No art. 29 numeral $1^{\circ}$ estabelece-se a remuneração básica de 5,02 cêntimos de euro por kWh durante a vigência dos contratos. Adicionalmente é contemplada uma remuneração para os primeiros cinco anos da operação do parque eólico que ascende a 9,2 cent/kWh que considera a fase inicial onde os custos costumam ser mais elevados em quanto se chega ao ponto de equilíbrio econômico financeiro. Também se estabelece um sistema de ampliação do tempo considerando o rendimento de referência do aerogerador o qual deve oscilar entre $0,75 \%$ de a partir do rendimento de referência e não pode superar 150\% desse rendimento. (Anexo 5 da EEG)

O aumento da retribuição básica encontrasse condicionado ao contemplado na Ordenança de serviços prestados ao sistema pelos aerogeradores e aplica para os parques eólicos que iniciaram seu funcionamento antes do primeiro de janeiro de 2014. Esta medida tende a que o sistema elétrico receba beneficio com o continuo desenvolvimento tecnológico da fonte eólica e ao harmonizar-se com o sistema de retribuições e primas, assim como evoluir em quando aos sistemas de conexão, evitando problemas de congestionamento das redes. 


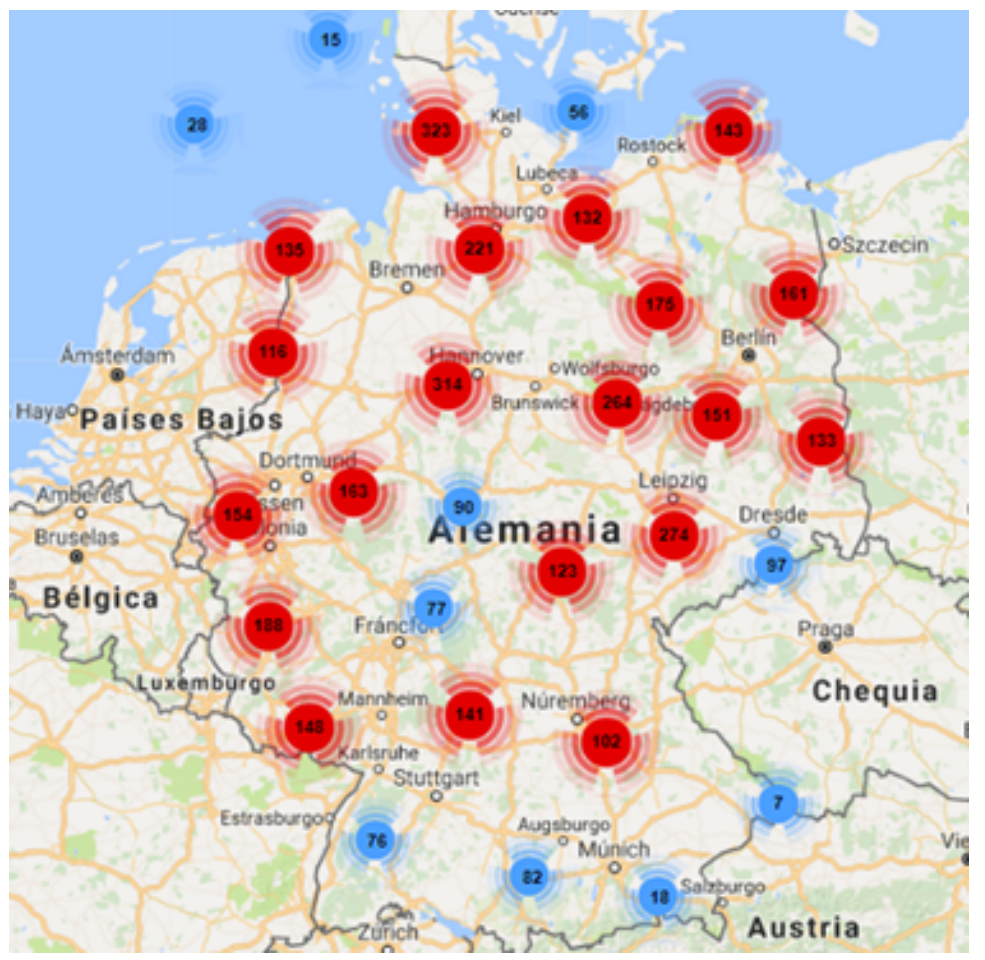

Figura 11 - Mapa eólico da Alemanha (fonte: WWE 2016).

Emquanto aos aerogeradores que são introduzidos no sistema que apresentem a caraterística de repotenciação, para ganhar as vantagens da eficiência dos novos aerogeradores e que isso redunde em beneficio da retribuição econômica, o artigo 30 da EEG após da reforma de 2009 determinou os diversos parâmetros para que surtam efeito, promovendo a continuidade da expansão da capacidade instalada de energia eólica e cujo efeito se evidencia no mapa das instalações eólicas na Alemanha de acordo com a figura 11.

\subsubsection{Planejamento energético na frança em função dos compromissos inter- nacionais}

Atualmente a atividade de planejamento energético é um assunto estratégico para o desenvolvimento econômico de qualquer pais, uma vez que é uma ferramenta vital na definição dos objetivos e dimensionamento da expansão energética em função das necessidades da demanda. Não obstante resulta indispensável incluir critérios ambientais que obedeçam as expectativas de redução de $\mathrm{CO} 2$ e paralelo a isso se dimensione um sistema energético confiável e seguro que responda satisfatoriamente à demanda. Neste âmbito o incentivo às fontes renováveis torna-se fundamental para dimensionar um sistema energético amigável com o ambiente, assim revisar-se-á os 
principais aspectos de planejamento em cada pais assim se observaram os respectivos planes e programas para a energia eólica.

O planejamento energético na França deve guardar observância às diretivas da união europeia, conforme disposto no artigo 194 do Tratado de Funcionamento da União Europeia que é o fundamento jurídico das competências compartilhadas entre a UE e os países membros em questão de energia. Entre os objetivos climáticos da UE encontram-se a redução das emissões de $\mathrm{CO} 2$, ter eficiência energética e desenvolver incentivos o incremento de energias renováveis. Sobre o assunto de energias renováveis encontram-se as seguintes decisões fundamentais neste tema:

Em 2001 o Conselho de Gotenburgo emitiu a diretiva 2001/77/EC na qual definiu a estratégia europeia para o desenvolvimento sustentável referente à geração de eletricidade com energias renováveis fixando uma meta de $21 \%$, este objetivo é uma diretriz de caráter indicativo desde 2001 e obrigatória desde 2006. Posteriormente na diretiva 2009/28/CE do Parlamento Europeu e do Conselho, que teve por objeto o fomento do uso de energia procedente de fontes renováveis foi determinado que cada estado membro tinha que estabelecer seu plano de ação nacional para 2020 fixando uma quota de energia renovável de 20\%. Em 2014 o marco para as políticas em matéria de clima e energia estabeleceu como objetivo vinculante para a UE que até 2030 pelo menos um $27 \%$ do consumo deve ser gerado com energia renovável.

De acordo com o contemplado no código de energia da França um dos objetivos da política energética é a preservação do meio ambiente e uma particular preocupação com o problema do efeito estufa. Estes objetivos estão consignados nos artigos $3^{\circ}$ ao $13^{\circ}$ da Lei №. 2005-781 e no capítulo IV da lei №. 2009-967 e no Plano Plurianual foi consignado que $23 \%$ do consumo devia ser atendido com energia renovável até 2025 . Pensando na efetividade desta política foi considerada como uma ação estratégica para a diminuição do uso de energias fósseis e o incremento da participação das renováveis para atender o consumo de eletricidade.

\subsubsection{Incentivos para energias renováveis em França}

$\mathrm{Na}$ França para ter FIT em primeira instância foi consagrada a obrigação de comprar a energia gerada a partir de fontes renováveis. As condições para usufrutuar este 
beneficio encontram-se atreladas à satisfação dos requerimentos do articulo L.314-1 do código de energia. Para tornar efetiva essa obrigação de compra, se assina um contrato com a empresa de distribuição de energia EDF, em que o preço é de 0.082 euros $/ \mathrm{kWh}$. A prerrogativa de FIT esta contemplada para ter duas fases com uma vigência de 15 anos, a primeira fase é de 5 anos e a segunda de 10 anos.

Com a lei de Grenelle II foram definidas, no artigo 90, o local de desenvolvimento eólico terrestre (zone de développement éolien terrestre - ZDE), com a finalidade de determinar em que lugar do território francês se estabeleceria a obrigação de compra. Inicialmente este beneficio era somente para energia produzida on-shore e as instalações efetuadas fora desta área geográfica não contavam com esta tarifa especial. Mas, posteriormente, foram suprimidas as ZDE pela lei № 2013-312 de 15 de abril de 2013, com o qual foi preciso desenvolver outro marco contratual para preservar a garantia de compra de energia que têm os produtores eólicos. Assim observa-se que ainda esta se consolidando o marco jurídico que contenha as regras de contratação da energia eólica na França.

A lei de transição energética francesa que atualmente esta sendo tramitada na Assembleia Nacional tem, entre seus objetivos, criar condições para desenvolver o mercado para as energias renováveis. Isso corresponde ao esquema de maior competitividade, onde as energias alternativas tem que responder com maior maturidade às condições de mercado. Nesta lei de transição energética vai ser regulamentada a complementação da remuneração para as energias, o que se conhece como tarifa premium no âmbito dos incentivos regulatórios. Isso obedece a uma lógica de mercado e se exige uma maior competitividade nos preços, diferente do que acontece com o sistema de remuneração FIT.

No artigo 23 do projeto de lei foi contemplada uma meta de atendimento à demanda de 32\% com energias renováveis até 2030 e o complemento da remuneração pelo qual posteriormente vai ser necessário regulamentar as condições para tornar efetivo este incentivo. Também foi previsto a exclusão de este benefício daqueles projetos de energia renovável que já estão se beneficiando com o modelo de remuneração dos contratos que fazem efetiva a obrigação de compra que tem EDF com os produtores de energia renovável. Se espera que com esta nova lei se substitua a obrigação de compra que foi o incentivo que permitiu que se desenvolvesse forte- 
mente a capacidade instalada de energia eólica, e este constitui um novo processo de incentivos onde se deve incrementar a competitividade para as energias renováveis.

\subsubsection{Barreiras para as energias renováveis na França}

$\mathrm{Na}$ França o planejamento e sua efetiva execução para os projetos de energia eólica tem se tornado um assunto complexo pela divergência de interesses dos diferentes atores envolvidos, pois não há consenso quanto às vantagens e da energia eólica. Um exemplo disso é o assunto referente à proteção da paisagem como argumento constante para restringir as autorizações de construção de parques eólicos, panorama que varia dependendo da região da França por que cada ente territorial tem autonomia para definir seus assuntos paisagísticos segundo a legislação de urbanismo.

Outro argumento é o direito a tranquilidade por causa do barulho que ocasionam os aerogeradores, assim como também a proteção da fauna por conta do distúrbio para as aves, assuntos estes que tem sua especial proteção dentro da legislação francesa. Então, sob estas condições as diferenças entre os defensores da política paisagista e os que defendem o desenvolvimento da indústria eólica ainda estão no processo de alinhar seus interesses em pro do desenvolvimento sustentável. Contudo, deve se propender por evitar um desequilíbrio no sistema administrativo que impeça a efetividade na execução da capacidade instalada em matéria de energias renováveis, permitindo que sua inserção seja mais harmônica possível.

De outra parte, existem locais que gozam de uma proteção ambiental e portanto requerem um estudo mais detalhado para a autorização administrativa da construção de usinas eólicas. Este tipo de medidas certamente restringe os objetivos de crescimento da capacidade instalada para energia eólica. Obviamente salvaguarda do meio ambiente é fundamental no processo de diversificação das matrizes energéticas e de maneira alguma podem resultar vulnerados. Mas também se requer de um limite claramente determinado para que os processos de solicitação de instalação de aerogeradores não se vejam obstruídos por falta de diretrizes concretas em matéria ambiental ou por alguma administração.

Igualmente, esta consagrada a discricionariedade administrativa às diferentes re- 
giões e departamentos para que resolvam seus assuntos em matéria de autorizações de construção de parques eólicos. Isso leva a que os processos para instalação e conexão às redes ainda não tenham suficiente agilidade que $o$ assunto merece. Principalmente por que se trata da execução de um objetivo estratégico para o desenvolvimento sustentável do país, pelo qual é indispensável trabalhar consolidação da segurança jurídica para que exista clareza nas regras, evitando que os tramites se tornem arbitrários y prevaleça a incertezas na gestão administrativa.

Sob estes pressupostos evidencia-se que não existe um procedimento estandardizado nos diferentes níveis da administração pública para que possam evoluir até um procedimento claro em matéria de autorizações administrativas para os empreendedores do setor eólico. Para tentar superar as questões burocráticas na nova lei de transição energética vai ser estabelecida uma autorização única que contemple os diferentes tipos de instalação de energia eólica no artigo 38.

\subsubsection{Irregularidades na implementação da tarifa de recompra da energia eó- lica.}

$\mathrm{Na}$ normatividade francesa se estabeleceu uma tarifa fixa predeterminada que garante a compra da energia produzida a partir de fontes eólicas, isso se encontra em consonância com o artigo L-314 do código da energia que estabelece esta possibilidade para as fontes renováveis de energia. Igualmente, sobre este assunto o Decreto No. 2001-410 de maio 10 de 2001 determina as condições de compra da eletricidade dos que se enquadram neste benefício.

Contar com uma tarifa garantida é um estimulo para que os novos investidores se interessem em entrar no mercado e diversificar os agentes garantindo que exista maior tendência à competitividade o que faz com que os preços do mercado se tornem mais favoráveis e seja possível desenvolver um mercado energético confiável. Atualmente essa compensação para os geradores eólicos esta sendo financiada pela Contribuição do Serviço Público da Eletricidade (CSPE) que gera um gravame fiscal para o consumidor final. Mas isso gera uma discrepância no sentido de que este tributo no foi originariamente desenhado para esse fim, além de que o intuito era sua distribuição entre os diferentes agentes do mercado, entendam-se produtores, distribuidores e clientes. 
Mas, esta normatividade foi demandada em razão a que supostamente se ocasionou uma desigualdade entre o valor fixado para a energia e, com relação aos outros produtores de energia, devido a que é consideravelmente superior ao atribuído as outras renováveis. Adicionalmente foi argumentado que não se efetuo com anterioridade à decisão da $\mathrm{EU}$, que era obrigatória já que se tratava de um auxilio concedido pelo Estado francês que favorecia o mercado interno (artigo 107 do Tratado de Roma), pelo qual perante a ausência da notificação à UE se constitui uma decisão ilegal.

O conflito se centra na natureza dos recursos com as quais será paga a tarifa garantida, já que foi determinado pelo Tribunal Europeu que estes recursos tinham a condição de vir do Estado Frances que também efetua o controle de estes recursos. $\mathrm{Na}$ decisão foi determinado que esta medida afetasse claramente a concorrência no mercado interno, pelo favorecimento aos produtores eólicos e também podia ser lesivo para os Estados membros. Frente a esta situação o Conselho de Estado Frances pediu a intervenção da Corte de Justiça da UE para que fosse resolvido se, em efeito tinha se infringido a normatividade da UE em matéria de intervenção do Estado no assunto da remuneração à geração eólica. A resposta foi dada em dezembro de 2013, e na decisão se confirma a ilegalidade do regime de remuneração para as eólicas na França.

Perante a necessidade de continuar crescendo em energia renovável, certamente a França não pode ficar sem incentivos para as energias renováveis, portanto tem que preservar os contratos que já preveem o beneficio da compra garantida. Toda vez que isso permite criar condições de segurança jurídica no mercado elétrico para os novos produtores de energia eólica. Os contratos existentes deverão cumprir-se para não gerar descumprimentos e instabilidades no sistema, mas para os projetos futuros é preciso criar outras condições de remuneração que correspondam com um cenário de maior maturidade para a energia eólica.

De outra parte, seguindo a tendência atual de transição legislativa que vislumbra diminuir os incentivos, netamente assistenciais, para as energias renováveis, com a intenção de conduzir e incentivar estas energias a um novo patamar ajustando seus modelos de negócios a um modelo mais competitivo. A normatividade francesa, em 2016 efetuo uma relevante modificação, e sobre ela resulta pertinente efetuar uma analise em termos de legitimidade e validade da ação legislativa. 
A nova proposta legislativa foi feita respeitando o princípio de irretroatividade da legislação, ao igual que foi feito na Alemanha, o que significa que o efeito da norma e sua aplicação efetuam-se para o futuro, ou seja, que ele somente surte efeitos a partir de sua entrada em vigor. O que quer dizer que com isso se preserva tanto a segurança jurídica quanto a confiabilidade do sistema normativo, o que constitui uma garantia ao pressuposto de Estado de Direito, onde as ações e decisões adotadas pelo Estado.

O planejamento do setor elétrico plasmado legislativamente em 2015, para o caso da energia renovável na França estabeleceu como meta para as renováveis entre o $32 \%$ e $23 \%$, quando comparado com outros países Europeus como Alemanha e Espanha, certamente apresenta uma porcentagem menor nesta meta ambiental. Mas a racionalidade desta decisão de política energética tem justificativa pela sua composição da matriz elétrica.

Mas parece ter uma discrepância entre seus objetivos inicialmente plasmados e a direção normativa adotada já que por meio do Decreto tarifário de 13 de dezembro de 2016 foram modificados os parâmetros de remuneração para a energia eólica. Escalonando o sistema de remuneração, com parâmetros diferentes de tarifa em consideração ao prazo dos contratos, assim para contratos de 15 anos o nível de complementação da tarifa é de $8.2 \mathrm{kWh}$ para os primeiros 10 anos e oscila entre $2.8 \mathrm{e}$ $8.2 \mathrm{kWh}$ (Euros), nos seguintes 5 anos. Mas o critério para a diferença de tarifa no segundo caso, esta condicionada à localização do projeto.

O sentido da reforma legislativa procura suas modificações basicamente de uma parte estabelecer novos parâmetros para ter acesso aos benefícios, isso associado desde a perspectiva do mercado com o critério de concorrência pelo mercado; e de outra parte uma variação nas condições de remuneração, que criaria um novo patamar onde a pertinência em termos de justiça distributiva não se encontram legitimados. $O$ efeito jurídico destes novos parâmetros, corresponde a o fenômeno da concorrência que pretende ser inserido no setor eólico, mas também tem como efeito colateral de desarticulação das políticas ambiental e energética. 


\subsubsection{Energias renováveis na Colômbia}

Pode-se afirmar que quanto à normatividade sobre energias renováveis a Colômbia ainda se encontra na fase inicial do processo de regulamentação. Evidencia-se que, desde a Constituição Política, no artigo 79 se encontra consagrado o direito ao meio ambiente saudável e no artigo 80 enuncia que "o Estado planificará o manejo e aproveitamento dos recursos naturais para garantir o desenvolvimento sustentável". Tradicionalmente a matriz elétrica colombiana pode ser considerada limpa, já que pelo menos $70 \%$ da demanda é atendida com a fonte hidráulica, então os passivos ecológicos ocasionados pela geração de energia elétrica não apresenta maiores contribuições de $\mathrm{CO} 2$. Mas a hidráulica tradicional não se considera sustentável completamente já que tem impactos ambientais, com comprometimento sobre a fauna e flora.

Não obstante, a preocupação com a mudança climática faz com que se acordem internacionalmente uma série de compromissos para aprimorar tanto o planejamento quanto a gestão dos recursos naturais. Uma das dimensões da sustentabilidade é justamente o incremento de capacidade instalada de energias renováveis.

Mesmo sendo um país com uma matriz elétrica em princípio limpa, é preciso acoIher as recomendações sobre incremento de energias renováveis. Um dos problemas que pode ser revolvido estrategicamente através das Energias renováveis é o da cobertura da prestação do serviço público de energia elétrica. Segundo os dados da UPME de 2016 observa-se que existiam 216.250 famílias que não tem o serviço (IPSE) com o propósito de aumentar a cobertura se conta com subsídios como recursos do fundo de apoio financeiro para a energização das Zonas Rurais Interconectadas (FAER) e o fundo de apoio Financeiro para a energização das Zonas não interconectadas (FAZNI).

No plano indicativo de expansão de cobertura do serviço de energia elétrica aborda- se o tema da cobertura como um fator de intervenção do Estado nos serviços públicos e implica uma gestão permanente. Desde a perspectiva jurídica, certamente contribui com o princípio de universalização dos serviços públicos que foi um dos parâmetros estabelecidos na lei 143 de 1994, com a qual se oficializou a mudança do modelo regulatório para o setor elétrico. 
Um dos objetivos do desenvolvimento sustentável é a paz e a justiça. Com o recente acordo de paz assinado entre o governo nacional e as FARC espera-se acelerar o crescimento econômico da Colômbia. Justamente as áreas geográficas próprias para o desenvolvimento das energias renováveis tem sido as mais afetadas pelos enfrentamentos armados e uma das vias de resolução de conflitos é justamente trazer meios de trabalho a estas regiões, o que pode ser feito com a implementação das fontes renováveis. Certamente com o tema das energias renováveis o país pode encarar estrategicamente seus desafios no processo de paz, desde as perspectivas econômica, social e ambiental.

\subsubsection{Modelo regulatório para o setor elétrico e sua sustentabilidade em Colômbia}

Na Lei No.143 de 1994, uma norma específica para o serviço público de energia elétrica foi estabelecido com o objetivo fundamental da regulação de adequada prestação do serviço por meio do aproveitamento eficiente dos diferentes recursos energéticos. Esta premissa, certamente deixa o setor elétrico mais próximo dos objetivos ambientais e representa um convite para trabalhar na consolidação do desenvolvimento sustentável. Não obstante, a legislação colombiana tem sofrido um longo percurso para alcançar a meta da diversificação da matriz elétrica.

Embora deve ser salientado que mesmo sendo energias renováveis, se requer licenças ambientais dependendo do porte do projeto, o que requer apresentar também um diagnóstico ambiental de alternativas (1) e um plano ambiental. Mesmo sendo energias renováveis também se produz uma externalidade ambiental negativa que precisa ser avaliada com a finalidade de determinar o risco de dano ambiental e as possibilidades de mitigação ou compensação. Devido à necessidade de ter um plano ambiental, sua execução requer uma constante avaliação por parte das autoridades ambientais na Colômbia onde geralmente no nível local são as corporações autônomas regionais as encarregadas de efetuar as auditorias e determinar se está sendo acatada a normatividade ambiental.

Uma prova do anterior é o fato de que a primeira lei que aborda o tema das energias renováveis é a Lei No. 1715 de 2014, expedida vinte anos depois da lei que implementou o modelo neoliberal para o serviço de energia. O propósito da nomeada 
lei, tem sido o incremento de capacidade instalada das fontes de energia renovável e sua incorporação efetiva no sistema elétrico nacional. Sendo o principal enfoque da lei a criação de incentivos tributários para atrair investidores ao setor, viabilizando o rápido retorno do investimento. Para tanto foram consagradas as seguintes regras:

- O sistema de depreciação dos ativos a 5 anos com o fim de diminuir os seus impostos.

- A possibilidade de diminuir da renda, o valor dos ativos vinculados à geração de energia renovável em um $50 \%$, para efeitos tributários dentro dos primeiros 5 anos de realização do projeto.

- Isenção do importo de venda e dos direitos das taxas da importação dos equipamentos, elementos, maquinaria e serviços importados para a execução dos projetos de energias renováveis.

Outra das características da lei é o incentivo à pesquisa, não obstante no contexto colombiano a pesquisa sobre energias renováveis é muito incipiente e não conta com o mesmo desempenho de países da região como o Brasil. Também não tem a incentivo brasileiro de ter produção nacional no que tange a equipamentos para a geração das fontes renováveis.

Basicamente a lei 1715 é o início para incentivar às energias renováveis e trata o tema de excedentes de geração para as autogeradores e cogeradores de energia e o tema dos incentivos tributários, mencionado anteriormente.

No que tange à governança dos projetos de energias renováveis observa-se uma contradição que prejudica o dinamismo das licenças e autorizações que se requerem para iniciar os empreendimentos. Esta falta de clareza da norma consiste em que não foi diferenciado o processo burocrático segundo o tamanho do empreendimento, colocando a todos os empreendimentos no mesmo patamar para efeitos de requerer as mesmas permissões administrativas, desincentivando a geração de baixa escala.

Esta é uma das maiores críticas da iniciativa normativa, já que para a aprovação dos projetos sem importar sua capacidade instalada tem que fazer a solicitação perante a Unidade de Planejamento Minero Energética UPME que é uma instituição 
governamental vinculada administrativamente ao Ministério de Minas e Energia. Logo depois da aprovação da UPME se requer apresentar novamente o projeto ao Ministério de Meio Ambiente e Desenvolvimento Sustentável, que é o organismo que finalmente resolve sobre a isenção das taxas cobradas por direitos de importação e os incentivos tributários.

A possibilidade de simplificar os tramites para os projetos que não superem os 3 MW deve ser ainda discutida, de tal forma que não se desincentivem os pequenos produtores que desejam participar no processo de transição energética. Este tipo de iniciativas legais permite avançar na democratização dos meios de geração de energia, e conseguem incorporar aos usuários na gestão dos serviços públicos, abrindo espaço para as soluções conjuntas aos problemas ambientais. Igualmente contribui à diminuição dos custos de energia ao longo prazo.

\subsubsection{Possibilidades jurídicas para ser gerador de energia elétrica na Colôm- bia}

Fruto da implementação do modelo neoliberal no setor elétrico colombiano e perante a necessidade de efetuar uma adequada vigilância e controle sobre este setor da economia que traz implícito o interesse geral, foi promulga a lei 142 de 1994 para serviços públicos residenciais.

Um aspecto relevante nesta normatividade é a visão de que o usuário no futuro poderia participar de forma proativa na prestação do serviço, isso se torna interessante desde a perspectiva das energias renováveis, já que elas têm seu maior desenvolvimento na sua fase inicial, graças à participação privada, já sejam pequenos o grandes investidores...(tal como aconteceu na Alemanha). Então, a norma objeto de estudo garante a participação efetiva do usuário na gestão e fiscalização do serviço e um dos mecanismos como se faz efetivo este postulado é justamente através da geração com energias renováveis.

Nesta linha encontra-se consagrada a figura do produtor marginal de energia elétrica, quando no artigo 15, numeral 2 da Lei 142 de 1994 se manifesta que entre as pessoas que podem prestar serviços públicos encontra-se: 
consequência ou complemento de sua atividade principal, os bens e serviços próprios do objeto das empresas de serviços públicos. (Tradução própria).

O anterior deixa em aberto a possibilidade de se constituir como produtor marginal, em consonância com o estabelecido sobre livre iniciativa privada na Constituição Política e com a função social e ecológica da propriedade privada. Sendo que não precisa pertencer exclusivamente ao ramo da atividade de energia para fazer parte das soluções energéticas, por meio de energia distribuída e energias renováveis.

Seguindo esta linha e de acordo com a normatividade para o serviço público de energia elétrica os produtores marginais são os seguintes: os autogeradores de conformidade com o artigo 11 da lei 143 de 1994 y com a resolução CREG 084 de 1996, e os cogeradores segundo a resolução CREG 085 de 1996, Resolução CREG 107 de 1998, Resolução CREG 32 de 2001, Resolução CREG 39 de 2001, Resolução CREG 141 de 2001, Resolução CREG 02 de 2002, lei 1215 de 2008 e Resolução CREG 05 de 2010.

A condição de produtor marginal tanto do autogerado quanto do cogerador é corroborado no conceito No. 846 de 2007 emitido pela CREG, onde esclarece o alcance da figura do produtor marginal, tomando como base a autogeração a cogeração e a geração marginal. O conceito de autogerador contido no artigo 11 da lei 143 de 1994, art. 11, da resolução CREG 119 de 1998 e na resolução CREG 84 de 1996 estabelece o seguinte:

Autogerador é aquela pessoa natural ou jurídica que produz energia elétrica exclusivamente para atender suas próprias necessidades. Pelo tanto, não usa a rede pública para fins distintos ao de obter respaldo do Sistema Interligado Nacional, e pode ou não, ser o proprietário do sistema de geração. (Tradução própria) (Tradução própria).

Então, segundo a normatividade colombiana e de acordo com o princípio de livre acesso as condições para se conectar na rede elétrica, para os autogeradores e cogeradores são: o respaldo de algum comercializador de energia, um contrato de conexão com o distribuidor local e um contrato de disponibilidade de capacidade de fornecimento de energia elétrica pela rede. Depois de cumprir as exigências técnicas 
indicadas pelo distribuidor local e ter assinado os contratos o efeito é a conexão com a rede de distribuição para garantir o fornecimento de energia em casso que o sistema de geração próprio apresente falhas. Isso é muito importante devido a que a continuidade no serviço de energia tem que ser preservada o máximo possível e isso têm duas perspectivas. De uma parte se encontram os requerimentos técnicos estabelecidos pela CREG e de outra se encontram os requerimentos jurídicos estabelecidos pelo distribuidor local.

Em caso de que o processo de conexão com o operador local não resulte expedito o produtor marginal ainda tem a possibilidade de acudir ao regulador para solicitar uma servidão de acesso à rede. Esta figura jurídica mesmo sendo um tramite da legislação civil, para efeitos de energia elétrica se faz como um tramite do direito administrativo, já que se trata de um assunto de serviços públicos e envolve o critério do interesse geral.

Do estabelecido na normatividade colombiana pode se inferir que se encontram suficientes bases jurídicas para brindar confiabilidade aos usuários, sejam pessoas naturais ou jurídicas, para participar ativamente do processo de geração a partir de fontes renováveis. Mesmo com a normatividade de energias renováveis ainda estar na fase de implementação, as figuras jurídicas existentes como produtor marginal, bem seja como autogerador ou como cogerador de energia, a garantia do livre acesso à rede de energia e os modelos contratuais que existem, são condições suficientes para que o negócio das energias renováveis comece a dar os resultados de crescimento e expansão em capacidade instalada.

Evidencia-se a importância para diversificar a matriz elétrica e manter a segurança no sistema, assim entendido se justifica a necessidade de contar com um suporte normativo solido que permita atrair investimento de capital privado para o setor elétrico e que essa nova apertura para agentes econômicos seja feita de forma democrática. Essa democracia participativa que estimula as pessoas jurídicas de direito privado a participar ativamente no desenvolvimento da vida econômica do pais.

A diferencia do Brasil que o tramite para acesso à rede elétrica para a geração distribuída que estabelece um tempo para resolver o assunto, mediante as Resoluções da ANEEL No. 482 DE 2012 e, No. 687 de 2015, na colômbia os distribuidores locais 
não tem essa obrigação de dar uma resposta em um tempo especificado nas normas do setor elétrico. Esta situação claramente pode ser interpretada como uma falência do procedimento de conexão, que pode levar inclusive a comprometer a eficácia da garantia do direito de livre acesso.

\subsubsection{Segurança energética como pressuposto para desenvolver a fonte eó- lica na Colômbia}

Com o fim de ganhar competitividade econômica a Colômbia precisa das fontes renováveis, mas não é somente esse aspecto a ser destacado com a atual revolução energética que representam as energias renováveis, também está a questão da segurança do sistema. Este pais teve uma crise de racionamento entre 1991 e 1992, precisamente pela sua alta dependência 'a fonte hidráulica, assim aspectos naturais como o fenômeno el niño onde tem períodos secos e os reservatórios não atingem o nível requerido para geração elétrica, nesta situação a probabilidade de ter crises energética de racionamento incrementa.

Para fazer frente a esta questão do risco da natureza foi emitida em 1998 a resolução da CREG 119, que estabeleceu o estatuto do racionamento, nele foi onde apareceu pela primeira vez a referência da figura do autogerador e cogerador com possibilidade de aumentar a disponibilidade de energia elétrica e participar no momento da crise. Este seria o começo da percepção da importância da proliferação da oferta de energia por parte da geração, e a importância da diversidade das fontes. Só que no cenário não ficou muito claro para os novos geradores qual seria o retorno e as condições de participação no setor elétrico. Este tipo de lacunas normativas faz com que entrar no setor elétrico ou participar nem que seja indiretamente nele seja pouco interessante para os investidores, portanto com esta iniciativa não teve muito impacto no setor e não represento nenhuma mudança significativa no mercado.

Novamente em 2015 sai uma regulação da CREG No. 171, salientando a importância de aumentar a geração para ganhar confiabilidade na oferta de energia, especialmente no que tange a usinas menores e sua participação no mercado varejista, sob a condição de ter garantia de potência no caso dos geradores e com isso mitigar os riscos do mercado. 
De qualquer maneira, mesmo com um pequeno incremento de geradores marginais (geradores e cogeradores) a possibilidade de racionamento é uma realidade. Porem uma das formas de reduzi-lo é diversificando a matriz energética, mas para que esteja em harmonia com os objetivos de desenvolvimento sustentável, essa diversificação deve ser em fontes alternativas. O que implica grandes mudanças desde muitos ângulos, tanto no aspecto normativo quanto no tecnológico, mas não principalmente mudanças que tenham o potencial de perdurar no tempo e se adaptem 'as condições específicas do setor elétrico colombiano, conseguindo ajustar as perspectivas de crescimento econômico e porem de consumo de energia com as soluções energéticas ambientalmente sustentáveis.

\subsubsection{Possibilidades de desenvolvimento da Energia eólica na Colômbia}

Quando revisado o conceito de desenvolvimento sustentável evidencia-se que ele abrange uma dimensão econômica, social e ambiental. Estes três elementos devem guardar uma certa coerência e harmonia entre eles no momento de definir as estratégias do desenvolvimento. Pontualmente a energia eólica, como as outras fontes alternativas, encontram como eixo central os três elementos nomeados na sustentabilidade, o que leva a inferir que o impacto também é ambiental na diminuição das emissões de $\mathrm{CO} 2$, social na democratização da produção de energia e o maior comprometimento do consumidor final no processo de transição energética e econômico na medida em que contribui com geração de emprego, redução de custos do setor ao longo prazo, levando em consideração os custos de operação e manutenção, partindo da base de que sua fonte primaria não tem custo.

Justamente estes três aspectos do desenvolvimento sustentável que é desenvolvido pelas energias renováveis. A própria lei 1715 de 2014 estabelece que a geração de energia elétrica a partir de fontes renováveis é uma questão de interesse público e utilidade social. Assim também observasse que muito do desenvolvimento da fonte eólica é o fruto de grandes esforços e investimentos realizados pelo setor privado, não só porque é um tema que possa gerar lucro, senão que vai além da produtividade e se vincula e compromete com o ambiente.

Os países em via de desenvolvimento como é o caso da Colômbia, encaram o 
processo de transição energética, não somente desde a perspectiva tecnológica, senão também a partir do desenho de políticas públicas que lhe permitam viabilizar a incorporação das mudanças significativas nos modelos de produção de energia elétrica. Certamente a tecnologia é importada nesta primeira fase para energia eólica, principalmente da Espanha e do Brasil, e são poucos os resultados de pesquisa e desenvolvimento, pelo qual o processo requer para começar a ter resultados de sucesso um grande impulso de políticas públicas, mesmo com uma lei de energias renováveis como é a lei 1715 de 2014 e o decreto do Ministério de Minas e Energia No. 2143 de novembro de 2015.

Não obstante, ainda falta afiançar a transição do setor elétrico para as energias alternativas entre elas a fonte eólica através de políticas públicas que concretizem os incentivos econômicos. Bem seja, contribuindo ao equilíbrio dos preços para permitir a entrada no mercado competitivo, ou estabelecendo tarifas diferenciadas para que concorram com as energias convencionais. Pelo tanto, os incentivos precisam ir além dos aspectos tributários e estruturar os instrumentos de mercado que garantam a inserção das fontes na matriz energética, no sistema interligado nacional e no mercado elétrico.

No caso da energia eólica que precisa de um investimento maior no início quando comparado com as outras fontes renováveis como a biomassa e solar, no caso de não contar com incentivos regulatórios adequados ou que a regulação tenha um impacto negativo por causa de barreiras regulatórias que condicionem seu crescimento. Concretamente precisa ser revisado o efeito regulatório desde a perspectiva do mercado, constatando se os instrumentos que oferecem a normatividade aporta segurança jurídica e viabilizem a efetiva inserção da fonte eólica na matriz elétrica colombiana. Sob a ótica da segurança jurídica vai ser analisada crítica e sistematicamente a normatividade atual sobre energia eólica, levando em consideração o aspecto do mercado.

Certamente quando novos agentes vão entrar em um mercado que tem tantas particularidades como é o setor elétrico requer um desenvolvimento de regras novas para vislumbrar as possibilidades de participação no mercado de curto ou de longo prazo e o leque de possibilidades de contratação, com as peculiaridades próprias das energias alternativas, que sem sombra de dúvida envolve novos riscos regulatórios e financeiros, assim como os aspectos de mitigação de riscos pela participação no 
mercado.

Devido ao precário desenvolvimento tecnológico da colômbia em matéria de equipamentos para geração de fontes renováveis, se abriu a possibilidade de ter isenção de taxas de importação para os equipamentos vinculados com a geração de energia elétrica a partir de fontes renováveis. A diferença do que acontece em países onde a política exterior é mais protecionista com a indústria nacional, a Colômbia tem que permanecer aberta para receber e incorporar a tecnologia limpa ${ }^{1}$.

Para conseguir um verdadeiro avanço em matéria de instalação de energias renováveis é imperioso contar com uma forte vontade política. Essa vontade política se materializa com objetivos de inserção das fontes renováveis a longo prazo e que proliferem os agentes vinculados aos projetos, democratizando a geração e permitindo que os particulares sejam proativos na transição à energia sustentável.

Ao certo com relação ao desenvolvimento da fonte eólica na Colômbia, os impactos da nova legislação somente vão poder ser medidos após a regulamentação efetiva da Lei 1517 de 2014. Adicionalmente ainda está pendente o desenvolvimento de políticas públicas que permitam efetivamente a implementação e uma planificação e gestão eficiente dos recursos elétricos. Já que quando se trabalham os objetivos ambientais e energéticos no nível de políticas públicas. Assim, a política pública permite trabalhar com o foco nas necessidades, requerimentos e particularidades locais, criando soluções que tenham uma alta probabilidade de efetividade por conta do vínculo entre as estratégias desenhadas na política pública e as condições locais da sua aplicabilidade.

Ainda é prematuro medir o impacto da normatividade de energias renováveis no mercado elétrico colombiano, especialmente por que os poucos processos existentes tem sido desenvolvidos como energia distribuída. Então, o processo de adaptabilidade à rede ainda está incipiente, e os novos geradores bem sejam autogeradores ou cogeradores vão precisar não só de uma normatividade estável como também de uma

\footnotetext{
${ }^{1}$ Que en la sesión 282 del 27 de abril de 2015, el Comité de Asuntos Aduaneros, Arancelarios y de Comercio Exterior recomendó la regulación del procedimiento para que quienes hagan inversiones en proyectos de FNCE que tengan la aprobación del Ministerio de Minas y Energía, o la entidad que este delegue, se beneficien de la exención del pago de aranceles para maquinaria, equipos, materiales e insumos destinados exclusivamente para labores de pre-inversión y de inversión en proyectos con dichas fuentes, que no sean producidos a nivel nacional.
} 
política pública que reflita suas necessidades atuais e contribuam com sua adaptabilidade ao sistema técnico e garantam seu acesso e participação dentro do mercado elétrico.

Considera-se que a grande meta das energias renováveis na Colômbia é justamente sua incorporação à rede e ao mercado. Para o qual se requer criar as condições básicas da regulação e das possibilidades de negociação estruturando o mercado de curto e longo prazo e o sistema de competição com outras tecnologias de geração.

Com a expedição da lei 1715 de 2014 começou formalmente o desenvolvimento dos incentivos para energias renováveis, com o foco de conseguir os objetivos propostos no plano decenal de energia e em concordância com o planejamento econômico do Estado. Infelizmente coincidiu com a possibilidade de ter uma crise no setor elétrico por conta do fenômeno de la niña e os esforços do setor elétrico se concentraram em resolver a contingencia. Pelo tanto esta norma só veio a ser regulamentada parcialmente até o final de 2015.

Com o decreto 2143 de 2015, definem-se os lineamentos para a aplicação dos incentivos da lei 1715, esta norma já deixa claro que os que geradores que se beneficiam podem ser tanto os autogeradores quanto os que pretendem participar do mercado elétrico, mas para se beneficiar do decreto precisa que sejam projetos novos, ou seja, que os benefícios não sejam retroativos para os empreendimentos. Uma das particularidades que apresenta é que é o primeiro em incentivar a pesquisa e o desenvolvimento para a tecnologia vinculada as energias renováveis.

Quanto aos incentivos financeiros se destaca a dedução especial na determinação do imposto de renda, compreendendo tanto as atividades de pesquisa e desenvolvimento como a produção mesma de energias renováveis e a eficiência energética. A partir dessa classificação surge o direito de deduzir até o $50 \%$ do valor dos investimentos para efeito de cálculo do imposto de renda, uma vez se obtenha a certificação de benefício ambiental que emite o Ministério de Ambiente e Desenvolvimento Sustentável, em concordância com o estabelecido no artigo 158-2 do Estatuto Tributário.

Deve ser especialmente considerada a regra sobre restituição do importo de renda em caso que os investimentos efetuados se vejam comprometidos em anulações de contrato, anulações de resoluções de autorização ou rescisões de contratos associ- 
ados às energias renováveis. ( art. Artículo 2.2.3.8.2.5)²Para aceder ao benefício da exclusão do imposto sobre a venda se requer previamente que a Unidade de Planejamento Mineiro Energético da Colômbia, emita um listado dos produtos que se encontram associados aos processos de geração de energia renovável.

\subsubsection{Risco Regulatório para a Energia eólica segundo a análise dos países comparados}

Para avaliar o grau de pertinência e a racionalidade jurídica das normas que regulam o processo de inserção da fonte eólica, segundo o que se evidencia na legislação revisada nos diferentes países comparados, o risco regulatório constitui uma variável não pode ser obviada pelos investidores que entram no setor. Embora todas as atividades econômicas tragam implicitamente um risco, é notório que perante uma crise econômica, dos Estados, a probabilidade de comprometer os incentivos que tem sido estabelecidos para a fonte eólica, não se encontram brindados juridicamente. Isso quer dizer que o pressuposto de confiança legitima no sistema jurídico pode sofrer uma míngua, o que paralelamente representa a desvirtuação do princípio de segurança jurídica.

Parte-se da premissa de que as regras para entrar em um novo negocio incentivado pelo próprio Estado, e o Estado como instituição legitimada, beneficia-se do atributo da validez das normas que emite. Mas quando por alguma razão se vê na necessidade de alterar o ordenamento jurídico, deve levar em consideração os efeitos, é dizer o alcance que ditas alterações terá quanto existem expectativas econômicas consolidadas em torno à normatividade vigente. Aqui o problema não é a alteração do ordenamento jurídico tendente a permear situações jurídicas já consolidadas, o que gera desconfiança na própria atividade de planejamento e regulação do Estado, o qual tem um efeito direito no comportamento econômico de um determinado setor, como por exemplo no caso de estudo, o setor de energia eólica.

Fruto de uma normatividade jurídica que brinda confiabilidade, em quanto à pos-

\footnotetext{
${ }^{2}$ Exclusión del IVA: La compra de equipos, elementos y maquinaria, nacionales o importados, o la adquisición de servicios dentro o fuera del territorio nacional que se destinen a nuevas inversiones y preinversiones para la producción y utilización de energía a partir FNCE, así como aquellos destinados a la medición y evaluación de los potenciales recursos, de conformidad con la certificación emitida por la Autoridad Nacional de Licencias Ambientales de equipos y servicios excluidos del impuesto, para lo cual se basará en el listado elaborado por la UPME y sus actualizaciones.
} 
sibilidade de obter uma taxa de retorno interessante para os investidores derivou-se a proliferação das instalações eólicas foi consequência da legislação que a teve bastante eficiência para incentivar aos investidores a esta forma de geração de energia elétrica. 


\section{CONCLUSÕES}

Com o presente trabalho pretendeu-se efetuar uma análise da situação da energia eólica tendo como linha de pesquisa o direito ambiental, com fundamento na metodologia trialista para abordar um ramo do direito contemporâneo, onde para prever o alcance e efetividade do direito, deve ser considerado o plano axiológico, o plano realista e o plano normativo. Todo isso, desde a necessidade global de transição energética e de integrações regionais que abordam a transição energética de forma conjunta, com notórias necessidades de complementaridade, perante o qual a proliferação da fonte eólica resulta um fato indiscutível que deve ser analisado com sentido critico, tanto desde o contexto brasileiro quanto desde o contexto internacional.

Desde o anterior marco e guardando harmonia com os objetivos propostos apresentam-se as seguintes conclusões:

1. O momento atual de eco-desenvolvimento que estamos vivenciando, esta direitamente associado a um longo percurso da institucionalização do direito ambiental, em quanto instrumento básico na consolidação para a prevenção, mitigação, correção e compensação dos danos ambientais. Com a positivação dos objetivos do direito ambiental, materializado no arcabouço normativo nacional e nos tratados internacionais, encaminha-se a decisão e ação racional do Estado e das organizações internacionais, legitimando assim as políticas ambientais; a positivação dos objetivos do direito ambiental servem como referentes para a transição energética. $O$ anterior permite inferir que quando se incentiva uma fonte de energia alternativa, como é a energia eólica, isso redunda na materialização da validade e eficácia do direito ambiental e ganha espaço como área autônoma do direito, tornando mais fácil a efetividade dos direitos do meio ambiente.

2. O direito ambiental tem a função de regular as condutas do homem e a exploração dos recursos naturais, como exercício de uma consolidação histórica de direitos fundamentais, acolhidas pelas políticas constitucionais e legislativas dos Estados. Sendo a fonte de energia eólica desenvolvida juridicamente a partir dos princípios e postulados do direito ambiental, como são: prevenção e precação para evitar a 
ocorrência de danos ambientais irreversíveis, desenvolvimento sustentável e transpersonaliazação do direito sobre os recursos naturais. Do anterior se infere que o bem jurídico implícito do direito ambiental, desde o seu conteúdo meta-jurídico e finalístico, encontra nas fontes renováveis, um instrumento que viabiliza a consecução de alguns dos fins ambientais, pela sua importante contribuição de danos ambientais irreversíveis como o efeito estufa, aquecimento global e mudança climática, e em si própria ao desenvolvimento sustentável.

3. Uma evidencia da institucionalização do direito ambiental, aplicável ao recurso eólico, é oferecida pela regulação específica sobre inserção desta fonte na matriz elétrica. Pelo tanto, foi deduzido o plano de eficácia do direito no que tange às garantias para dotar seu regime jurídico da segurança jurídica, requerida em uma nova realidade de negócio. Tudo isso, no cenário de livre concorrência e aceitando a possibilidade de participação do investimento estrangeiro direito.

4. A segurança jurídica no presente caso de estudo, deve ser avaliada tanto a partir do ponto de vista regulatório e do ponto de vista contratual. Na relação de segurança jurídica referente ao marco regulatório se pondera a relação entre o Estado, os investidores e a sociedade, qualificando o interesse geral imerso em dita relação. Quanto à segurança jurídica em termos contratuais, que diz respeito às relações entre os investidores do negócio de energia eólica, destacam-se os seguintes aspectos: os investidores são atores determinantes para o processo de inserção da fonte eólica; é iminente a necessidade de preservar o equilíbrio econômico e financeiro dos contratos; deve existir certeza nas garantias previstas sobre vigência contratual, a funcionalidade prática do direito é influir nestas relações jurídicas privadas, vislumbrando que a transição energética seja uma realidade e se preserve a confiabilidade do funcionamento do setor elétrico, no longo prazo.

5. Os recursos naturais são bens coletivos da humanidade, sua titularidade jurídica é atribuível a todos os seres humanos, e justamente por isso supera a âmbito da soberania do Estado, por conseguinte estes bens coletivos são tratados como bens jurídicos passiveis de proteção, além de adotar a visão biocentrista da relação homem natureza, esta se aceitando a necessidade de tratamento internacional para seu planejamento e gestão. Trata-se, por tanto, de destacar que nessa relação homem natureza o direito tem incidência no que tange à sustentabilidade dos recursos naturais, 
no sentido de que pondera juridicamente sua capacidade ambiental, isto é, sua capacidade de regeneração, vislumbrando a preservação dos recursos naturais. Neste último sentido destaca-se este aspecto da sustentabilidade dos recursos, e sua aplicabilidade específica no caso da energia eólica, por ter a virtualidade de contribuir à sustentabilidade ambiental; não só otimizando a utilização do vento como recurso natural, também pelo destaque na sua contribuição para a diminuição das emissões de $\mathrm{CO} 2$.

6. Incrementar a participação das energias renováveis, como eixo fundamental dentro da transição energética é uma questão de responsabilidade que têm os Estados, responsabilidade que encontra a solução cabível com a materialização prática do desenvolvimento sustentável. A premissa do desenvolvimento sustentável a partir do viés político gera duas possibilidades: de uma parte é um princípio nos ordenamentos jurídicos do Estado-nação, com fundamento constitucional, presente nos países objeto de comparação desta pesquisa; mas por outro lado, a partir da sociedade internacional (poder de policia ambiental internacional) também encontra eco no contexto globalizado do sistema jurídico, que leva inclusive a apelar por um direito suave ou soft Law, justamente em prol da efetividade na interpretação e na aplicação do direito.

7. Certamente o direito como objeto de conhecimento tem problemas de ambiguidade e vacuidade quando se quer dar extensão a seu conteúdo acrescentando um bem jurídico passível de proteção pelo direito, como no caso do ambiente; aqui surge uma serie de complexidades para estabelecer sua proteção jurídica e propender pela concretização do objetivo. Isso se expressa na dimensão deontológica ou do dever ser que encarnaria a justiça ambiental. Este aspecto, quanto aferido com a necessidade de consagração normativa, e sua consequente eficiência (o que encarna a proteção jurídica holística), leva à aplicação de uma interpretação com supremacia do valor ambiental.

8. O processo de determinar o alcance da justiça ambiental é norteado pelo critério da eco-ética aplicável ao tratamento do ambiente como bem jurídico coletivo, atribuindo-Ihe a característica de interesse prevalente quando o Estado tem que executar a ação política de elaboração, interpretação e aplicação do direito. Este fundamento filosófico- político é o viés com o que se afrontam as decisões ambientais, bem seja no plano legislativo, executivo e judicial, mas também se encontra presente no 
desenho da política exterior dos estados.

9. O Estado em sua obrigação de preservar os valores, o interesse geral e o bem-estar comum decide sobre múltiplas questões fundamentais para a realização dos seus fins últimos, consagrados nas suas Constituições Políticas. Uma das suas responsabilidades prima facie aloca-se na adequada prestação de serviços públicos, entre eles o de energia elétrica, e a eficácia desta tarefa abrange o planejamento do setor elétrico, que estrategicamente deve estar alinhado com a política ambiental. Sendo determinante para focar a ação política na inserção de uma determinada fonte, tal como acontece através de políticas públicas que criam o cenário para a agilização da inserção da fonte eólica. A decisão política que esta amparada na segurança e confiabilidade que representa para a matriz elétrica, a diversificação, e que requerem um analise dos aspectos técnicos, sociais e econômicos.

10. A transição energética é um fenômeno que abrange diferentes atores da sociedade, onde o Estado atua como garantidor, mas certamente a participação outros atores é um fator determinante para o sucesso dos planos e programas que incentivam às energias renováveis. Isso quer dizer que a transição energética marca uma mudança a partir do plano tecnológico e de inovação, com critérios técnicos que garantiriam condições de qualidade para cada fonte de energia; mas também a partir do plano da democracia participativa para o qual é fundamental a clareza nos procedimentos participativos e a garantia da sua efetividade, por que a igualdade para dar acesso à participação também requer estar garantida.

11. A supremacia do interesse público presente no direito ambiental encontra no risco regulatório uma variável divergente ou suposto antijurídico, fazendo com que esse interesse público alocado nos bens ambientais se tornem vulneráveis de desvirtuação por causa da ineficácia normativa. O efeito da anterior situação incrementa a possibilidade de que os atores relevantes para o desenvolvimento da fonte eólica encontrem vacuidade normativa o que colateralmente produziria um desincentivo por insegurança jurídica no direito positivo. O risco regulatório é um fator que se evidência como denominador comum, em maior o menor grau, nas regulações que conferem prerrogativas à fonte eólica e à temporalidade das prerrogativas consagradas a ela (FIT, tarifa premium, certificados verdes, incentivos fiscais, modelos contratuais confiáveis, entre outros). 
12. Com a institucionalização da transição energética, entre a diversidade de instrumentos desenhados e implementados em diversas latitudes destacasse principalmente o FIT. Isso se atribui a seu alto grau de confiabilidade contratual, derivado da clareza obrigacional ao garantir a compra da energia, dando com isso segurança no mercado, e ao garantir a estabilidade do preço de remuneração, o qual outorga confiabilidade financeira. A conjunção dos elementos de confiabilidade contratual e financeira consolida a segurança regulatória nos negócios jurídicos que se beneficiem deste modelo. Devido ao modelo FIT encontram-se alocados recursos públicos, e com o objetivo de preservar o princípio de justiça distributiva, a temporalidade da sua aplicação deve estar implícita no modelo. A avaliação da eficácia da política pública tem que considerar a variável de temporalidade, em função de projetar a maturidade da fonte renovável para garantir sua permanência no mercado, em um cenário competitivo, como são: a tarifa Premium, o modelo de tarifa complementaria, e os leilões.

13. Quando avaliado o recurso eólico no caso brasileiro, com suas particularidades de políticas públicas aplicáveis a este recurso e fruto da aplicação da metodologia de planejamento integrada de recursos, foi possível inferir a relevância da fonte de eólica em termos tendenciais e sustentáveis. Para tanto foram consideradas as dimensões social, econômica, ambiental e política, em termos tendenciais; e no referente ao cenário sustentável, foi destacada a energia eólica e seu potencial para oferecer uma alternativa de desenvolvimento sustentável mediante a redução de emissões de CO2.

14. No cenário da globalização quando se trata de abordar a proteção a problemas de caráter global como é o aquecimento climático e tratamento dos bens comuns como são os recursos naturais, o direito também em sua função catalisadora das problemáticas sociais the compete oferecer respostas. Mas para avaliar a pertinência do arcabouço jurídico a esta problemática, por sua forte influência internacional, certamente a concepção de soberania como atributo fundamental do Estado, se vê alterado em razão à ingerência da normatividade internacional nos ordenamentos jurídicos internos. Esse fenômeno é ainda mais arraigado quando se está no contexto das integrações regionais que com suas diretivas tem efeito vertical direito nos marcos normativos nacionais dos países membros.

15. No contexto das integrações regionais pela sua natural tendência da complementaridade e sinergia para afrontar problemáticas, quando o tema é energia elétrica 
a integração pretende abranger de forma conjunta as soluções sobre a continuidade do serviço, com a segurança e com a modicidade tarifaria, energias renováveis e eficiência energética. Por causa do anterior, as políticas públicas sobre os incentivos a fonte eólica tem origem no direito derivado da integração e quanto maior seja o nível de integração maior será a vinculação jurídica e o grau de obrigatoriedade para adotar as políticas internamente nos Estados membros. A razoabilidade prática por trás dos incentivos normativos, regulatórios e econômicos para a fonte eólica, correspondem a uma expectativa internacional, que é mais eficiente quando abordada a partir de uma integração regional com um nível superior, como é o caso da União Europeia, a diferença do que é abordado a partir das simples relações internacionais bilaterais, multilaterais ou integrações com um nível mais superficial.

16. No que tange à analise comparativa do marco regulatório que contempla os incentivos para as fontes renováveis, entre elas a eólica, observasse que as modificações legislativas, tem alterado os patamares para ter acesso aos benefícios financeiros, tem modificado alterações no modelo regulatório e em geral tem impulsionado um sistema muito mais competitivo, para aumentar a eficiência no setor das renováveis. Embora em termos de mercado a atualidade legislativa se encontre ajustada ao desenvolvimento e amadurecimento de um novo ator no setor, como são os geradores de energias renováveis, isso não pode ser implementado de forma abrupta sob o risco de comprometer a confiança legitima que o mercado deve ter com relação ao Estado e sua competência normativa.

17. Uma destacada contribuição do presente trabalho é o uso da epistemologia geral para conduzir o processo à transdisciplinariedade entre o direito, a economia e a engenharia, partindo de conceitos gerais de uso comum das disciplinas mencionadas, para dar-Ihes alcance contextual no que tange à energia eólica. De outra parte, também é notória a articulação dos marcos teóricos das diversas disciplinas o que denota interdisciplinaridade, dando lugar a conjunção de conceitos das disciplinas comprometidas na pesquisa. Considerando o plexo jurídico destacasse a contribuição da teoria trialista do direito que mistura os aspectos realísticos, normativos e axiológicos para abordar as problemáticas jurídicas contemporâneas como é o caso da energia eólica quando vislumbrada desde o direito ambiental. De outra parte, a metodologia do planejamento integrado de recursos que esta orientado a uma concepção holística para 
afrontar as problemáticas associadas com os recursos de energia elétrica

\subsubsection{Trabalhos Futuros}

- Igualmente deve ser analisada a importância da supranacionalidade nas decisões da política ambiental e energética, especificamente no caso da União Europeia que trabalha atualmente na conformação e estruturação do mercado comum da energia.

- Deve ser desenvolvida uma análise comparada sobre o problema da proteção de expectativa do investimento estrangeiro direito, isso especificamente atrelado ao fato de que como a tecnologia vinculada à energia está desenvolvida por poucos investidores, a questão da segurança jurídica, quando avaliada no contexto das relações comerciais internacionais apresenta contornos diversos, passiveis de avaliação jurídica e econômica.

- Considera-se relevante efetuar uma analise mais detalhada sobre o vinculo jurídico das energias renováveis com o e direito urbanístico. 


\section{REFERÊNCIAS}

P. NAVARRO.

ABEEOLICA. Com a força dos ventos a gente vai mais longe. 2011. On-line.

ABIDIN, C.; LAPENTA, E. Derecho ambiental. su consideración desde la teoría general del derecho. Cartapacio de Derecho. Revista virtual de Derecho, p. 1-25, 2007.

ALVAREZ, E.; GARRIDO, V.; TUR, R. Derecho constitucional. [S.I.]: Tecnos, 2017.

AMAYA, O. Constitución Ecológica de Colombia. Bogotá: Universidad Externado de Colombia, 2016.

ARAGÃO, A. S. Direito dos Servioos Públicos. Rio de Janeiro: Forense, 2005.

ARIÑO, G. Princípios de derecho público económico. Modelo de Estado, gestión pública, regulación económica. Granada. España: [s.n.], 2004.

AUTHOR. Ações Orçamentárias Integrantes da Lei Orçamentária para 2014. Brasilia, 2014.

Alternativas energéticas sustentáveis no Brasil. [S.I.: s.n.], 2014.

AXELROD, R. La revolución de la cooperación. Madrid: Alianza Universidad, 1986.

BARRERA, A. Perspectivas del derecho Ambiental en Colombia. Bogotá:

Universidad del Rosario, 2006.

BIAGUE, M. F. Modelagem da Carteira dos Recursos Energéticos no PIR:

Validação do Modelo no PIR de Aracatuba. Tese (Doutorado) - Escola Politécnica da Universidade da São Paulo, 2010.

BIRNIE, P.; BOYLE, A. International Law and the Environment. Oxford: Oxford University Press, 1992.

CAFFERATA, N. Los princípios y reglas del derecho ambiental. San Salvador: Pnuma, 2004.

CASALS, M. Cuadernos y debates 14, curso de técnica legislativa. In: Madrid: Centro de Estudios Constitucionales, 1989. (Ténica Legislativa I), cap. Planificación de la intervención legislativa.

CONCIL, G. W. E. Global Wind Market Report. 2017.

COUTINHO, D. Política pública como campo disciplina. In: São Paulo: UNESP, 2013. cap. O Direito nas Políticas Públicas.

COUTURE, T. G. An analysis of feed-in tariff remuneration models: Implications for renewable energy investment. v. 38, p. 955-965. 
CURSO de direito ambiental brasileiro. [S.I.]: Saraiva, 2018.

ENERGIA e relaćões internacionais. [S.I.]: Editora Saraiva, 2013. v. 2.

ENERGIA Eóica. São Paulo: SENAC, 2012.

FADIGAS, E.; FARIA, A. Energia Eóica. Barueri - São Paulo: MANOLE, 2011.

FERNANDEZ, J. El Derecho económico internacional de la globalización. Bilbao. País Vasco: Servicio Editorial Univ, 2010.

FERREIRA, H. T. Energia eólica: barreiras a sua participação no setor elétrico brasileiro. Dissertação (Mestrado) - Programa interunidades de Pós-Graduação de Energia. Universidade de São Paulo, 2007.

GELLER. Revolução energética: políticas para um futuro sustentável. Tese (Doutorado) - Faculdade de Economia, Administração e Ciência Contábeis, Universidade São Paulo, 2002.

GREENPEACE. Revolução Energética, a Caminho do Desenvolvimento Limpo. Terceira. Brasil.

GRUBB, M. J.; MEYER, N. Wind energy: resources, systems and regional strategies. In: ___. Renewable energy: sources for fuels and electricity. [S.I.: s.n.].

HABERMAS, J. Facticidad y validez: Sobre el derecho y el Estado democrático de derecho en términos de teoría del discurso. [S.I.]: Trota Editorial, 2010.

HERLD, D. La democracia y el orden global: del Estado moderno al gobierno cosmopolita. [S.I.]: Ediciones Paidós Ibérica S.A, 1997.

HOWLETT, M.; RAMESH, M.; PERL, A. Política pública seus ciclos e subsistemas. Uma abordagem integral. terceira edição. São Paulo: CAMPUS, 2013.

HUENTELER. International support for feed-in tariffs in developing countries?a review and analysis of proposed mechanisms. v. 39, p. 857?873.

HUME, D. Tratado sobre la naturaleza humana. [S.I.]: Libros en la Red, 2001.

KISS, A. De la protection intégrée de l'environnement à l'intégration du droit international de l'environnement. Revue juridique de l'environnement, v. 3, p. 261-288, 2005.

KLARE, M. Planeta sediento. Recursos menguantes: La nueva geopolítica de la energía. [S.I.]: Ediciones Urano, 2008.

LINDBLOM. Mudling through 1: a ciência da decisão incremental. In: Políticas públicas e desenvolvimento: bases epistemológicas e modelos de análise. [S.I.: s.n.], 2009. cap. 5.1, p. 161-180.

LORENZINI, M. E. Política Exterior, Alianza Estratégica y energía en América Latina. Las relaciones argentino-chilenas bajo la lupa. Rosario. Argentina: Homo Sapiens, 2011.

MACIAS, L. F. Introducción al derecho ambiental. Bogotá: Legis, 1998. 
MARQUES, F. BENS PÚBLICOS: Função social e exploração econômica. 0 regime jurídico das utilidades públicas. [S.I.: s.n.], 2009.

MATTMANN, M.; LOGAR, I.; BROUWER, R. Wind power externalities: a meta-analysis. Ecological Economics, v. 127, p. 23-46, 2016.

MITRANY, D. The Funcionalist Alternative. The Funcionalist Alternative.Classic readings of international relations. New York: Hartcourt Brace College Publishers, 1994.

MOSSET, J.; HUTCHINSON, T.; DONNA, E. A. Daño ambiental. [S.I.]: RubinzalCulzoni Editores, 2011. v. 1.

MOYA, F. D. Mecanismos financeiros para fontes de energia renováveis. In: Anais Encontro de Energia do Meio Rural. [S.I.: s.n.], 2006.

M.UDAETA. Novos Instrumentos de planejamento energético e o desenvolvimento sustentável school $=$ Tese de livre docência. Escola Politécnica da Universidade da São Paulo, year = 2012,. Tese (Doutorado).

NAVARRO, P. Régimen jurídico de las energías renovables en Andalucia. [S.I.]: Formacion Alcala SI, 2013.

NINO, C. Introducción al análisis del derecho. 2da. ed. Buenos Aires: Editorial Astrea, 2007.

NORTH, D. Institutions, Institutional change and economic performance. Cambridge: Cambridge University Press, 1990.

NYE, J.; KEOHANE, R. Transnational relations and world politics: An introduction. International Organization, v. 23, n. 3, p. 329-349, 1971.

ONU. Informe Brundtland. Informe de la Comisión Mundial sobre el Medio Ambiente y el Desarrollo "Nuestro futuro común". [S.I.], 1987.

OSTROM, E. Govering the Commons: The Evolution of Institutions for Collective Action. Cambridge: Cambridge University Press, 1990.

PAINULY, J. Barriers to renewable energy penetration; a framework for analysis. Renewable Energy, v. 24, p. 73-89, 2001.

PECES-BARRA, G. Los valores superiores. Sociedad Española de Filosofía Jurídica y Política. [S.I.]: Boletín Oficial del Estado, 1987.

PEREZ, L. Los derechos de la sustentabilidad: desarrollo, consumo y ambiente. [S.I.]: Ediciones Colihue, 2007.

PÁEZ, I.; RODRIGUEZ, G. Temas de derecho ambiental: una mirada desde lo público. Bogotá: Universidad del Rosario, 2012. (Colección Textos de Jurisprudencia).

PIERINI, A.; LORENCES, V.; COMPARATORE, L. Derecho ambiental: Aportes para una mejor planificación, gestión y control en materia ambiental metropolitana. Buenos Aires: Editorial Universidad, 2007. 
PLANO Nacional de Energia - PNE 2030. [S.I.], 2007.

PLANO Nacional de Energia ? PNE 2030. http://www.epe.gov.br/Paginas/default.aspx, 2014.

RAZ, J. The Concept of a Legal System: An Introduction to the Theory of a Legal System. Oxford: Oxford University Press, 1980.

RISCOTI. Inserção da energia eólica no sistema hidrotérmico brasileiro.

Dissertação de Mestrado - Instituto de Energia e Ambiente. IEE Universidade de São Paulo, 2011.

RODRIGUES, E. Setor Elétrico Brasileiro - estrutura, funcionamento, instituições e perspectivas para o controle. São Paulo: publisher, 2011.

ROJAS, C. Evolución de las características y de los princípios del derecho internacional ambiental y su aplicación en Colombia. Bogotá: Universidad Externado de Colombia, 2007.

SALOMAO. Panorama do setor de energia eólica. n. 39.

SANDS, P. Greening international law. London: Earthscan Publications Limited, 1993.

SCHLOSBERG, D. Defining Environmental Justice. Theories, Movements and Nature. Oxford: Oxford University Press, 2007.

SHIRATO, V. Livre iniciativa nos serviços públicos. [S.I.]: Fórum, 2012.

SOARES, J.; OLIVEIRA, L. 2006.

TIPOS DE LEILÕES. 2017.

TOMAS. Planeamiento general del estado energético a nivel nacional y subnacional. In: AUTONóMICO, F. M. G. A. de Estudios Parlamentarios y del E. (Ed.). La nueva agenda internacional de las regiones. [S.I.: S.n.], 2007. p. 1-18.

URIBE, D.; CARDENAS, F. Derecho internacional ambiental. Bogotá: Editorial Jorge Tadeo Lozano, 2010.

VASQUEZ, F. C. Valoración Economica del Ambient. Buenos Aires: THOMSON, 2007.

VEGA, P. K. L. de la; ANGUITA, P. M. de. La justicia con la naturaleza. Madrid: Dykinson, 2011.

WANG, J.; HU, J.; MA, K. Wind speed probability distribution estimation and wind energy assessment. Renewable and Sustainable Energy Reviews, 2016.

WILLIAMSON, O. The Mechanisms of Governance. [S.I.]: Hardcover, 1996.

ZERRAHN, A. Wind power externalities. Ecological economics, v. 141, p. 245-260, 2017. 